WHC-MR-0416

UC- 630

\title{
Miscellaneous Information Regarding Operation and Inventory of 618-11 Burial Ground
}

\author{
C. R. Webb
}

Date Published

June 1993

Prepared for the U.S. Department of Energy Office o Environmental Restoration and Waste N lanagement

\section{(28) Westinghouse \\ $\begin{array}{ll}\text { W. Westinghouse } & \text { P.O. Box } 1970 \\ \text { Hantord Company } & \text { Richland, Washington } 99352\end{array}$ \\ Hanford Operations and Engineering Contractor for the \\ U.S. Department of Energy under Contract DE-AC06-87RL10930}




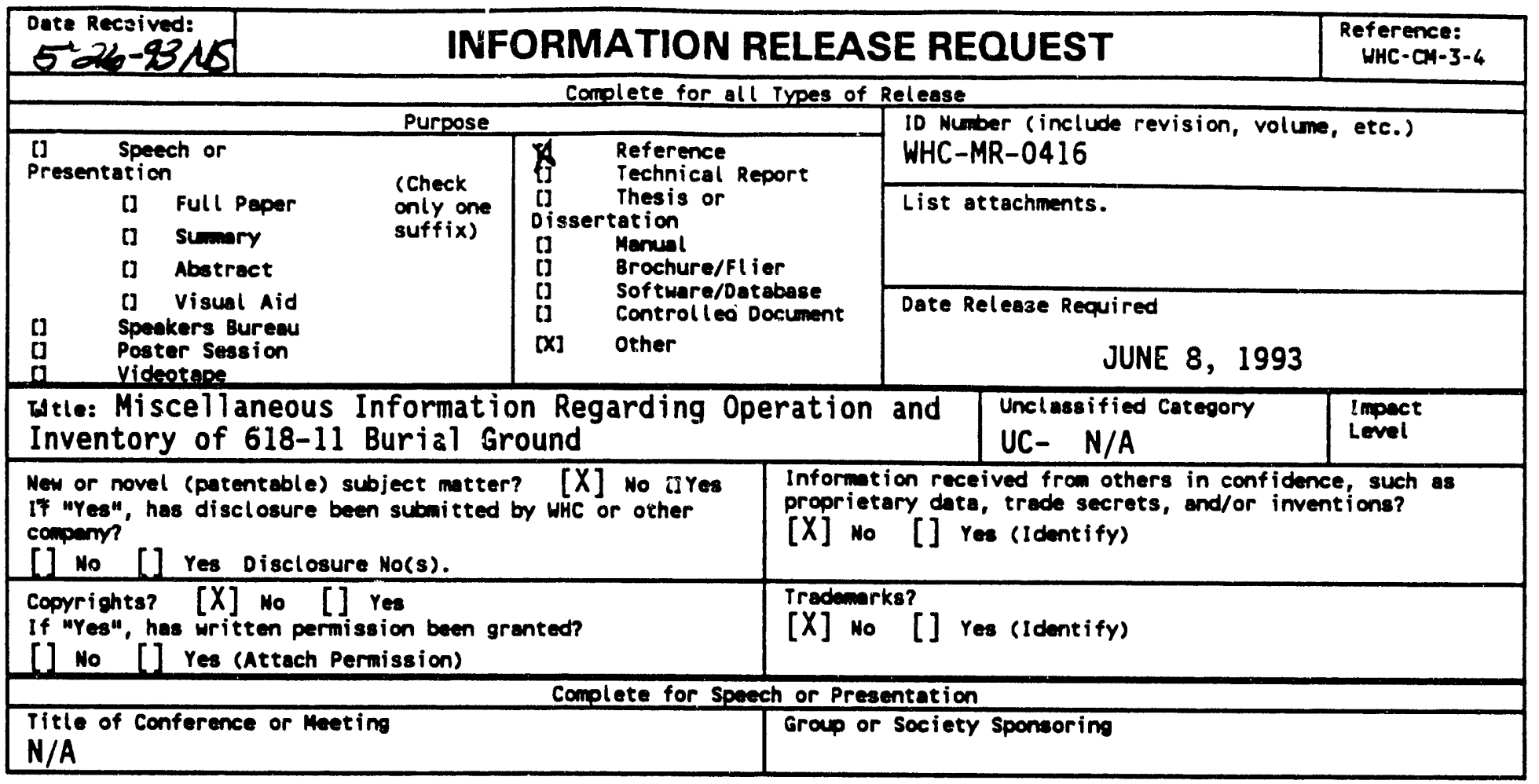

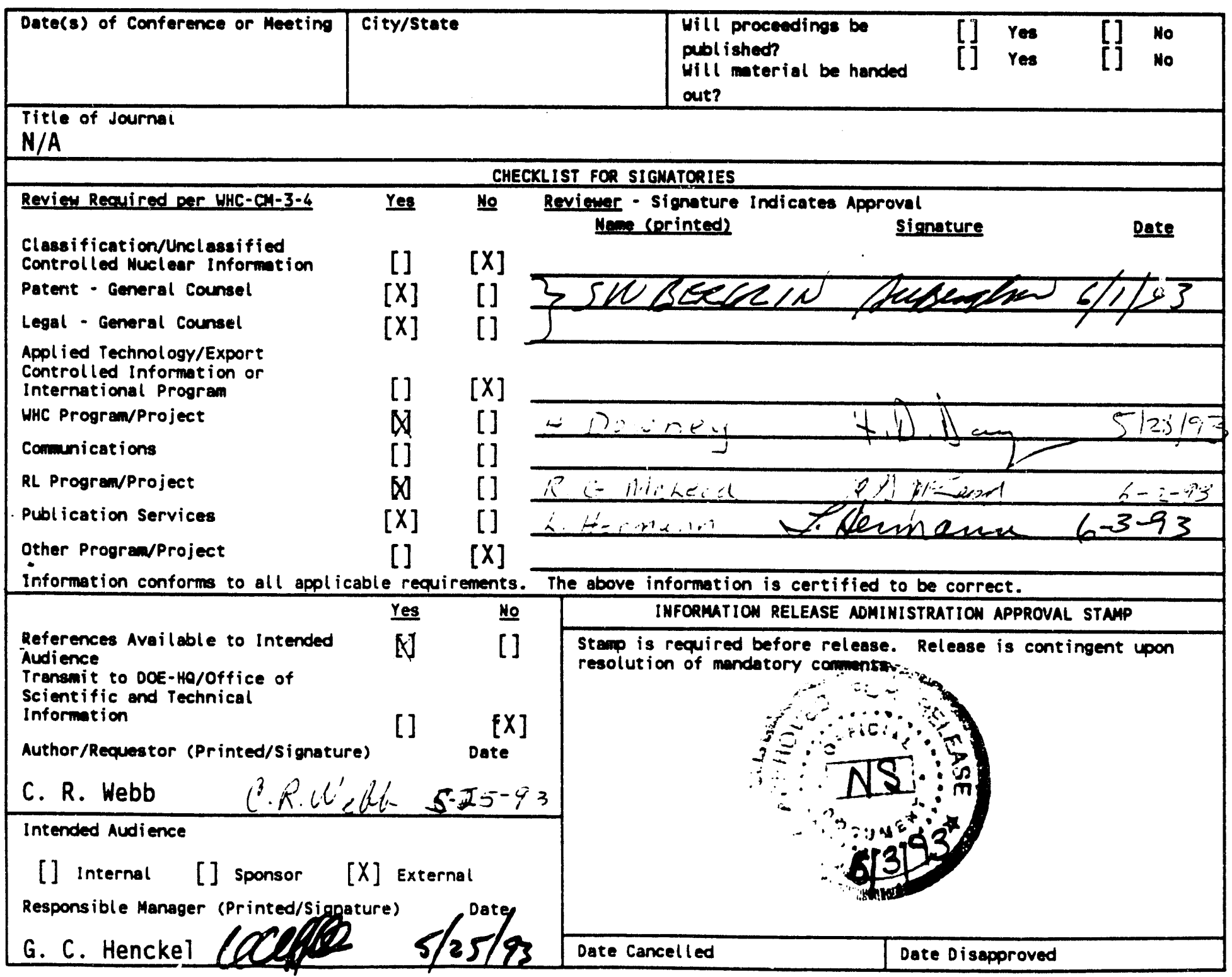




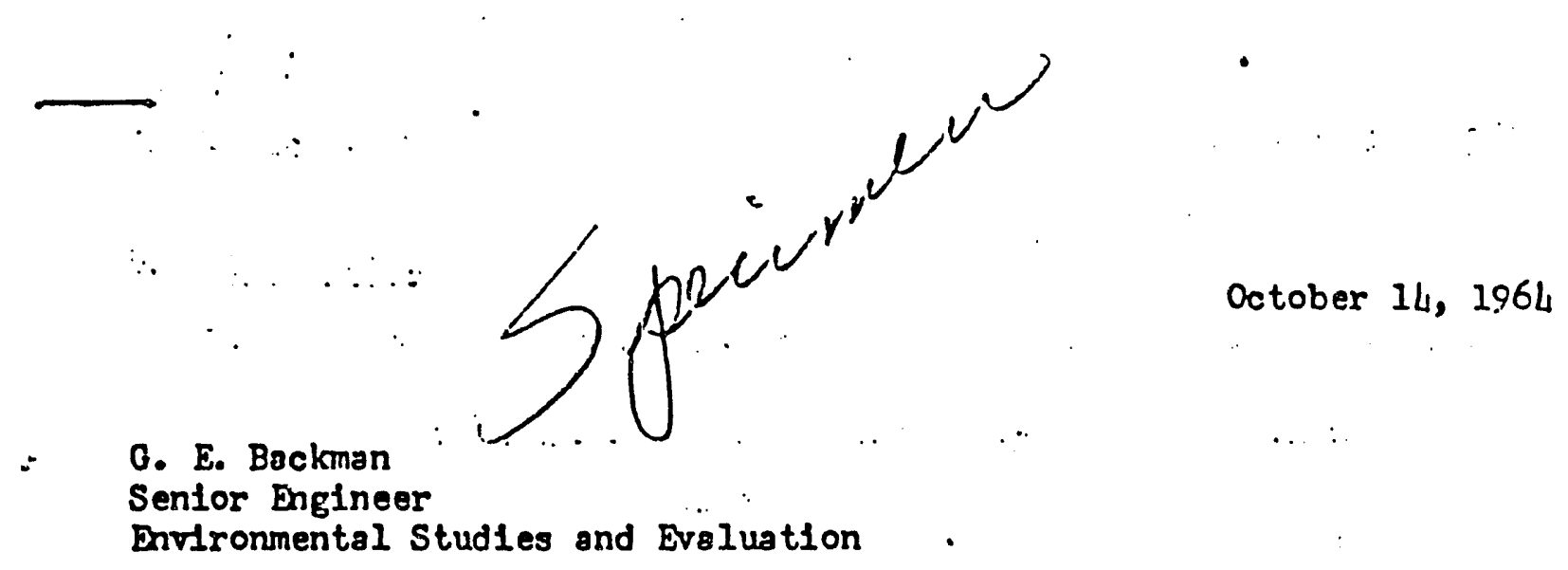

HOTE BRSFOSAL AHD FECONTAHIIATIOL, TONIHLY RABORT - SEFTETER TOGL

\section{A. 300-Wive Burial Ground}

i. No unusuel incidents occurred during tho month.

2. Wo IrFe aty weste dispose 1 tonks ot the 300-Wye Burlat Cround are nou in lne To date wo have had no problem in getting the waste boxes to travel to the bottom of the tanks.

3. There was some Beryllium waste from the 306 building deposited in the regular Beta-Gamma burial trench at the 300Wye Burial Ground during the month. Fermission was granted by the Safety Engineer for this operation.

4. ite $200 \mathrm{Al}$ Bwill Ground hes been terminated All permanent markers are in position. The fence has not been removed as yet. However, lir. lickinnon has promised to have it removed and placed in excess as soon as possible.

B. 307 Retention Easing

1. None of the basins exceeded the Class II activity levels during the month.

2. All components of the retention raste monitoring systems which have falled are boing returned to the vendor. We rill be unable to return the olpha detectors until construction personnel con disconnect them from the system. Since the pipefitters have ended their strike, we are hopeful we can return the alpha detectors sometine next month. 
D. 340 Operation

1. The following table sumarizes the Waste Disposal Operation:

Item

Concrete waste barrels disposed to 300-hye Burial Ground.

Concrete waste barrels disposed to 200-W Burial Ground.

Loodluggers of dry waste disposed to 300-Hye Burial Ground from 300 Area sites other than the 325 building.

Loadluggers of dry waste disposed to 300-liye Burial Ground from the 325 building.

Loadluggers of dry waste disposed to 200-H Burial Ground from 300 Area sites.

Containers of hiph level ory wnste disposed to 300-hye Burial Ground waste tanks.

Crib Waste Volune, Eal. Total Beta Conc., uc/gal. Total Beta, Curies Total Alpha Conc., uc/Eal. Total Alpha, me

Pu Concentration, ug/gal. Antt. Pu. $g$.

O. Concentration, ug/gal. Amt. U. g.
July

0

9

0

33

47

7

7

7

6

96

300,000

1400.0

420.0

2.74

822.0

11.7

3.51

7200.0

2160.0
10

Aug

Supervisor

haste Disposal and Decontamination

R. L. PLerce:IH

cc: RLP 


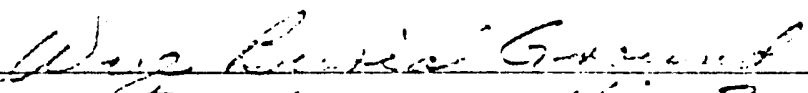

In

C

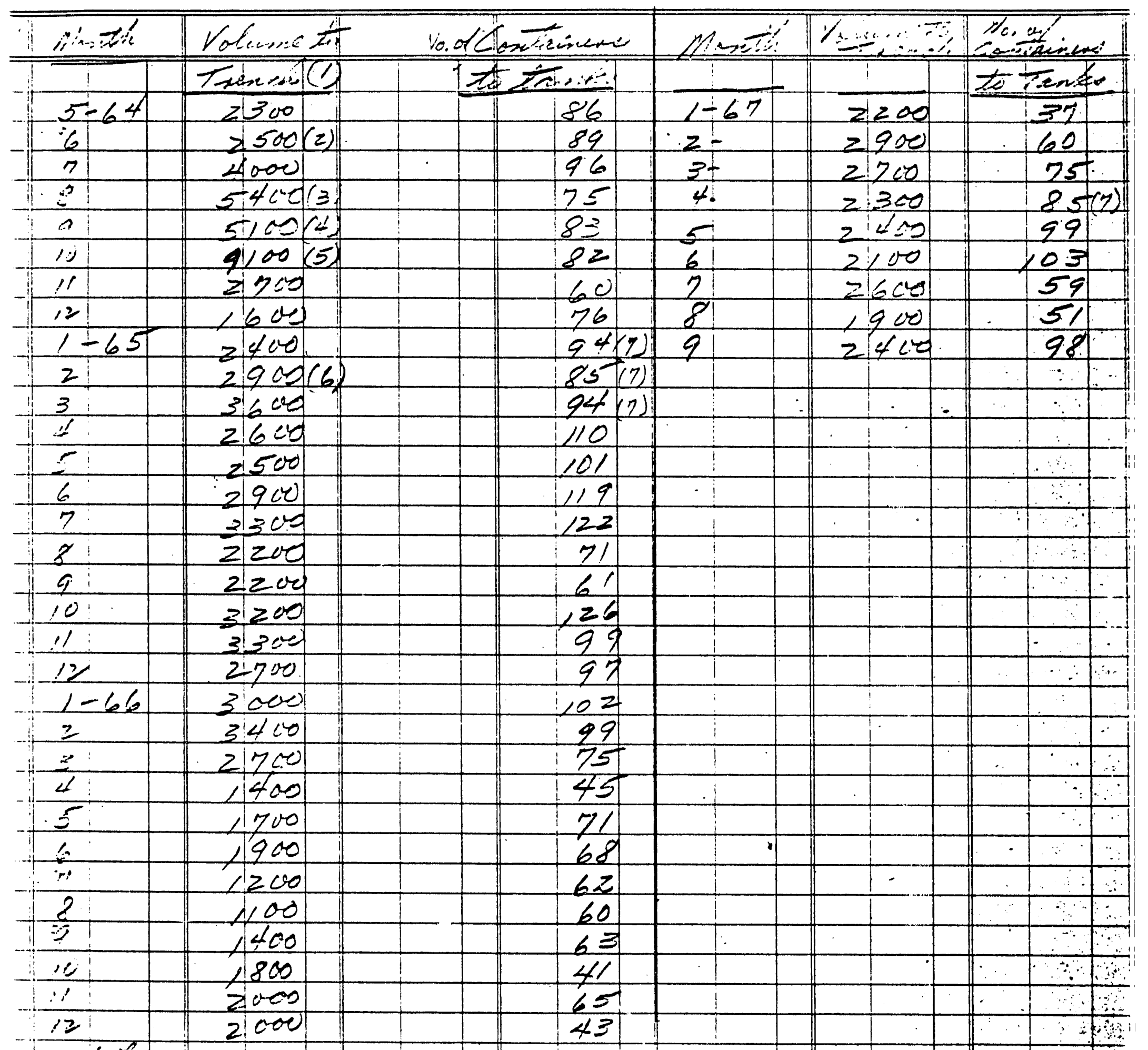

Alateses

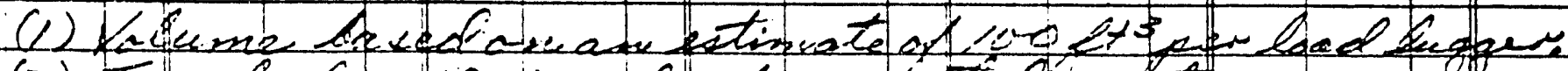

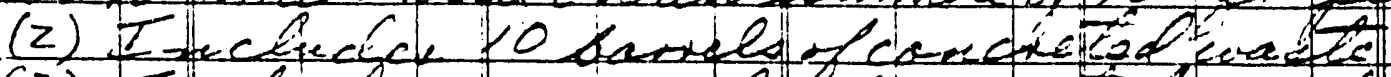

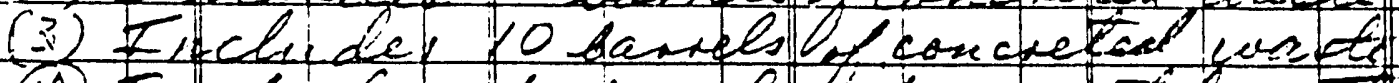

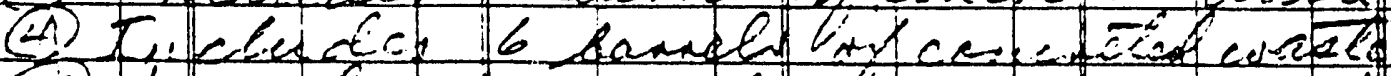

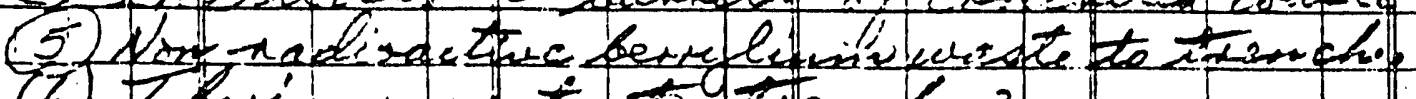

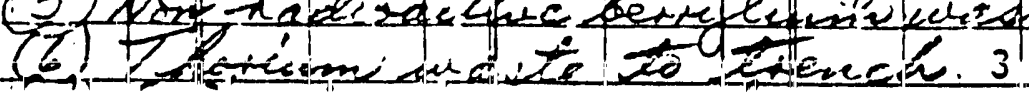


WHC-MR-0416

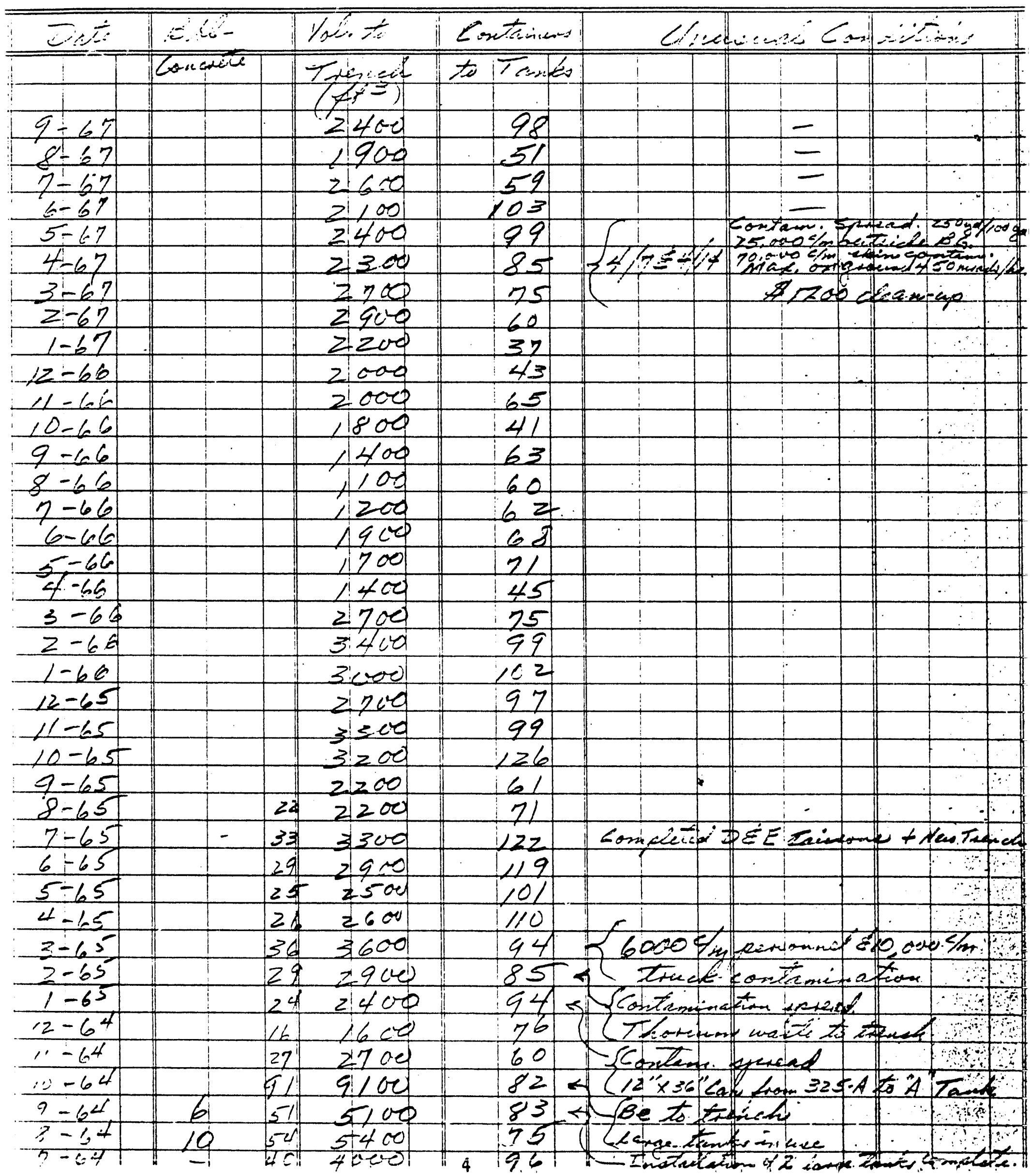




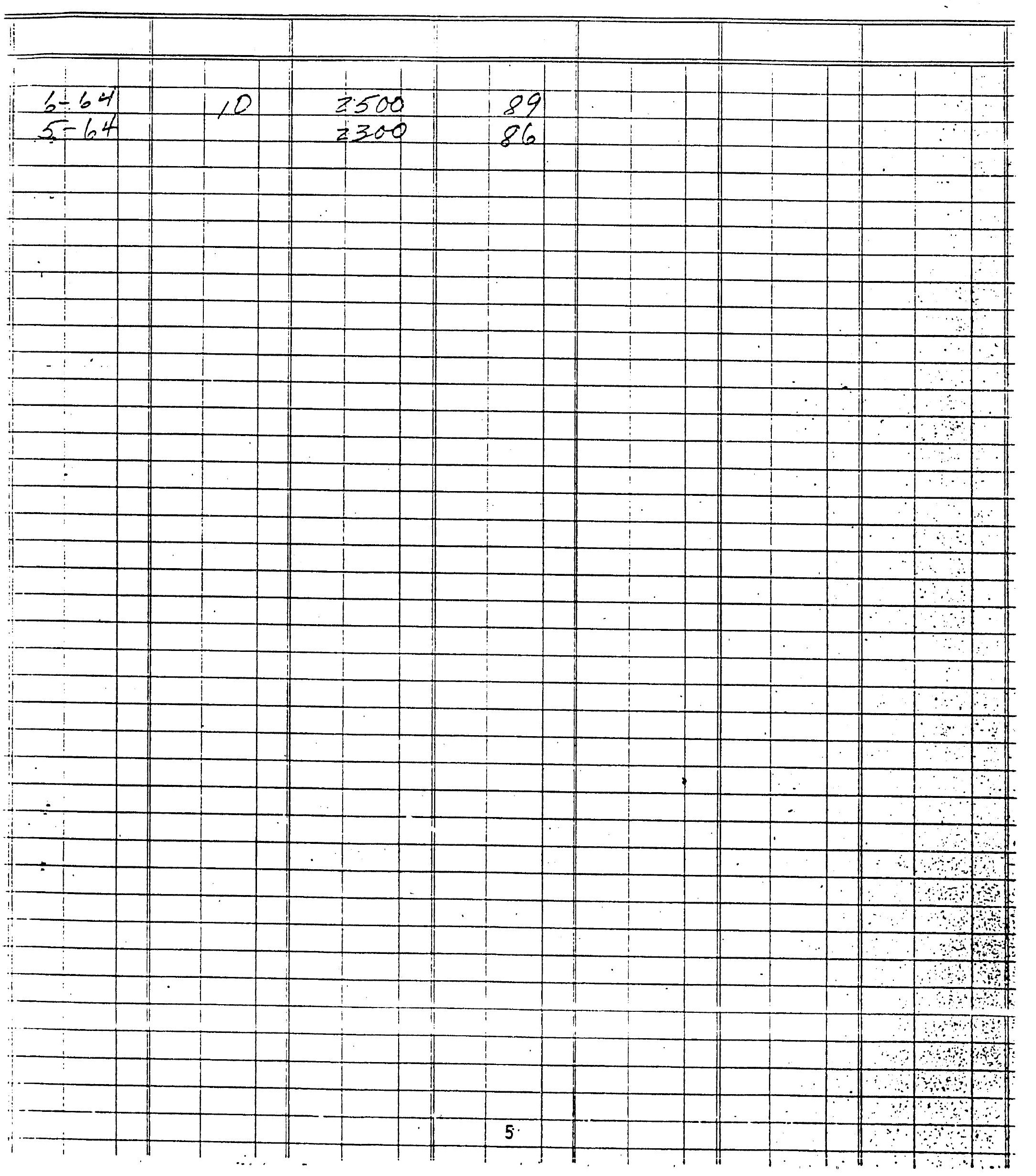


0 WHC-MR-0416 O Wye $\beta$ K E . A Tak

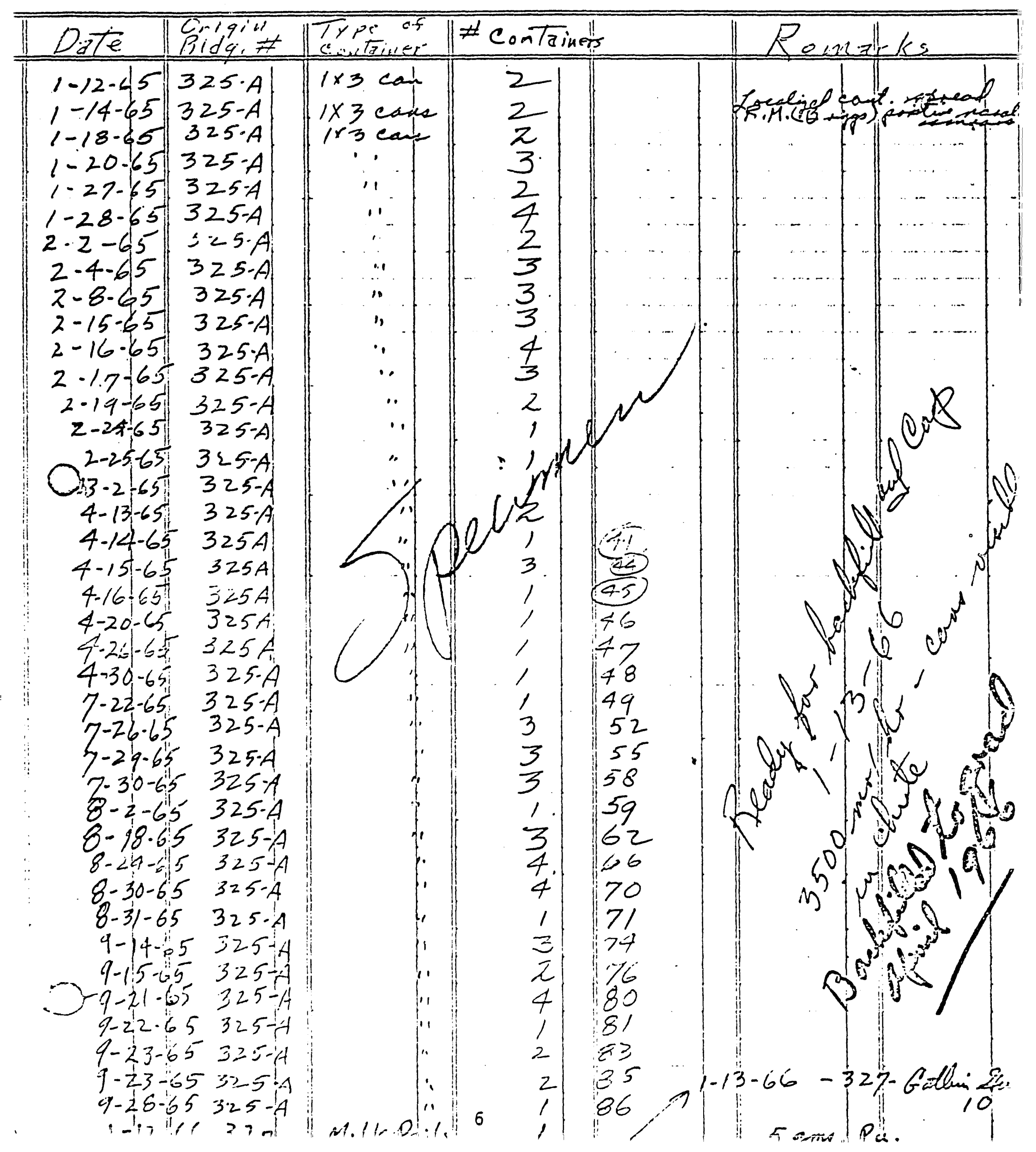




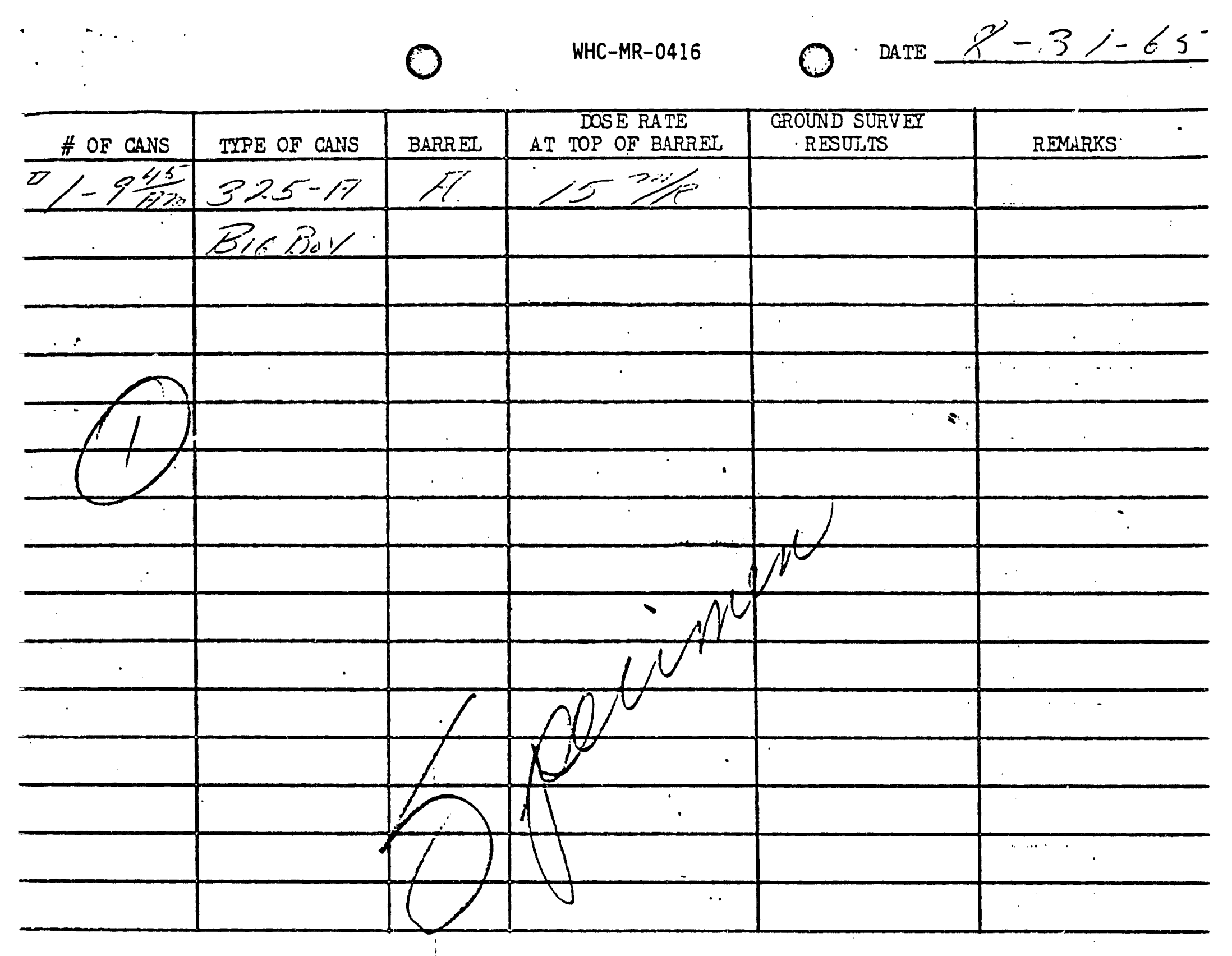

STATUS OF BARRETS AFTER EACXYIIIIING

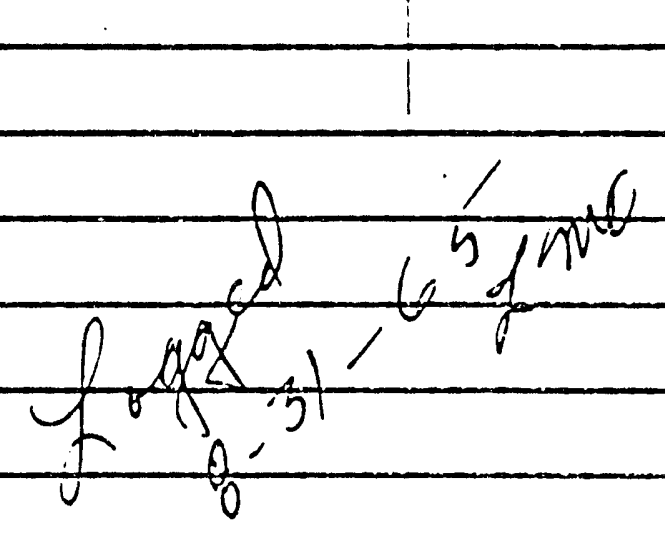

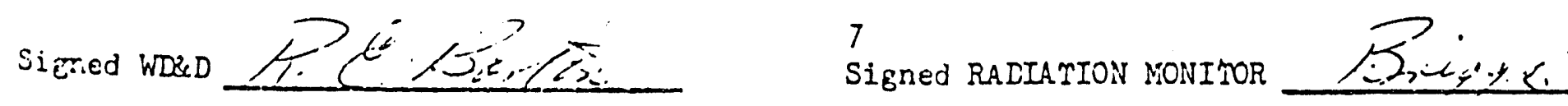




$$
\therefore \quad \text { Shipp }
$$

Both

DUiINL SITE - 300 ilorte (ino) : See notes below

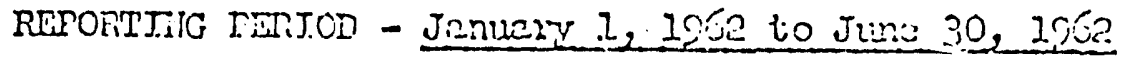

Racionoctivity

Icral

$10-1000 \mathrm{c} / \mathrm{sin}^{3}$

Under $10 \mathrm{c} / \mathrm{rt}^{3}$

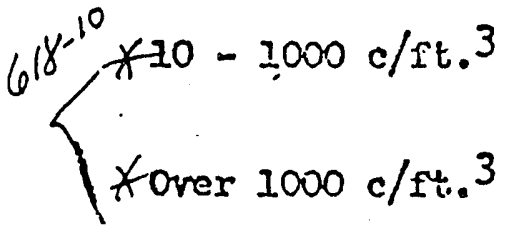

Under $10 \mathrm{c} / \mathrm{fu}^{3} .3$

Uniter $10 \mathrm{c} / 14.3$

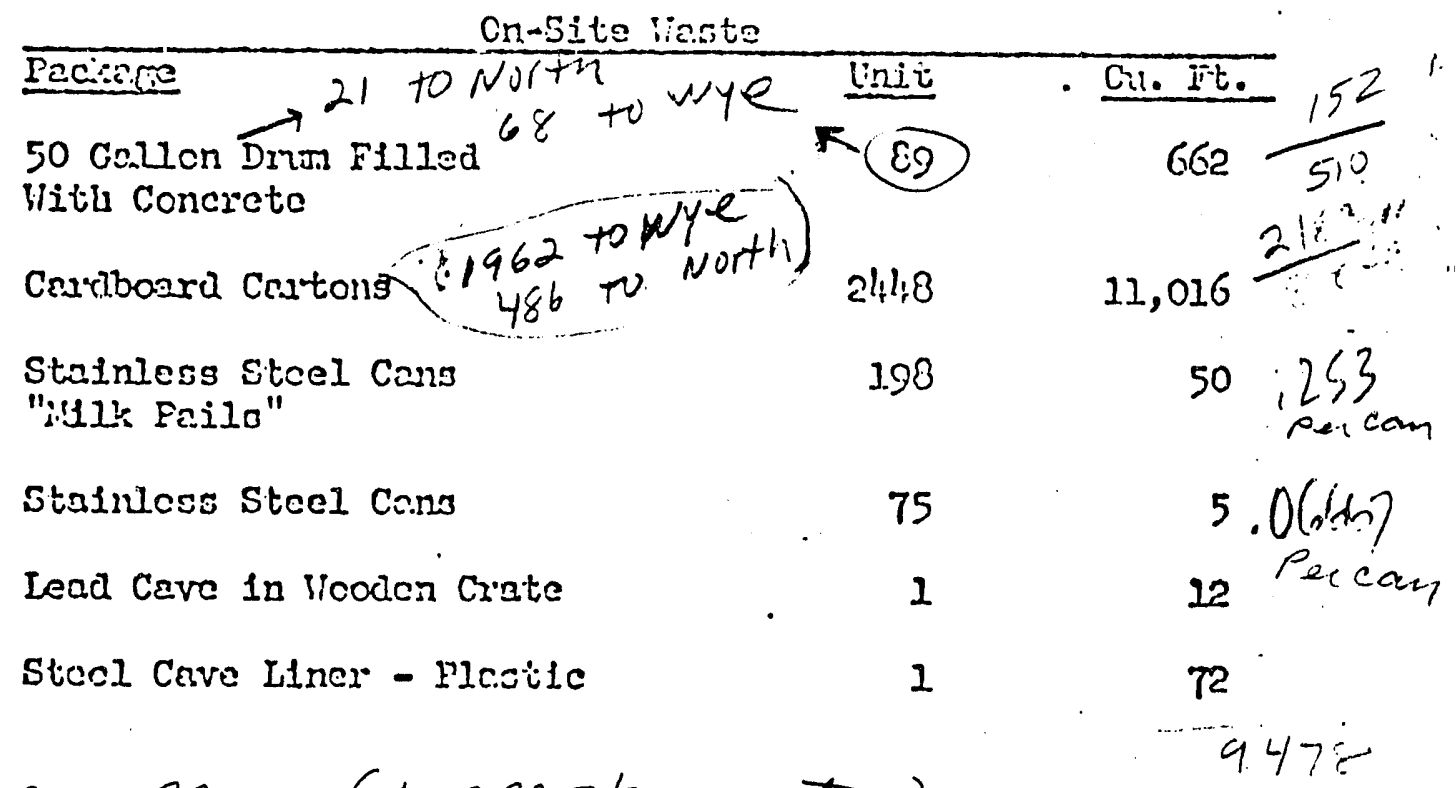

pipe 5 torage (ata)
sept 63

6 scios

$$
\begin{aligned}
& \text { Sant teth } \\
& \text { marcliper irty, Julle = wye }
\end{aligned}
$$

'ise ielenticie' 3-7-62

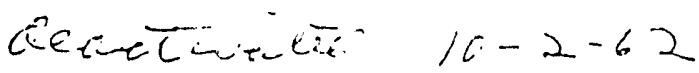

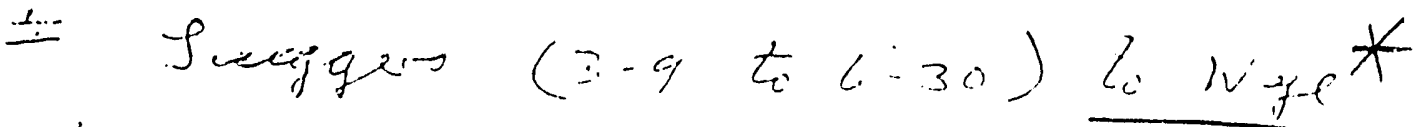

(18 Poxpes pist

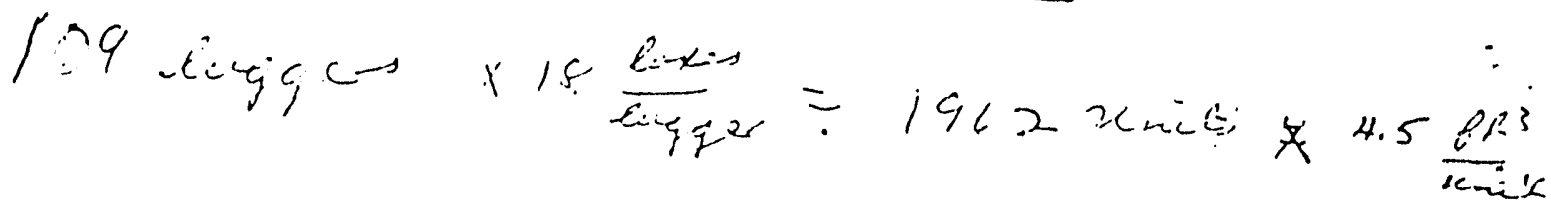

Sriqger to

$=8,5.29$

2. 4145

$-\frac{15.2}{486}$

11016

5829

$1 \%$-i-cionel, te Yew

510 eis e t

2157 en íl.

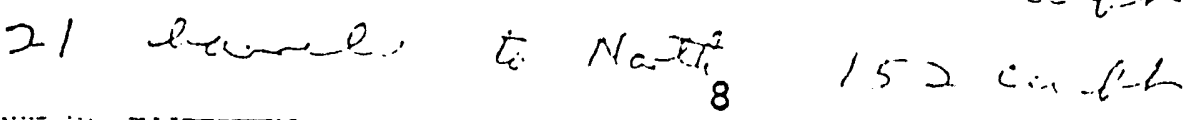


WHC-MR-0416

. bURIAL SIIE - 300 vice only

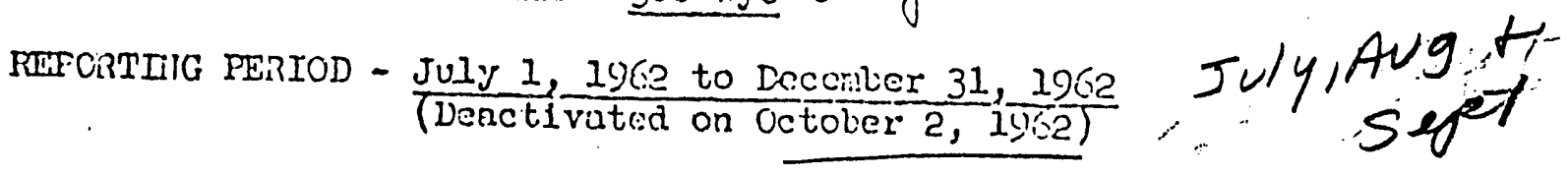

Radioactivity

$\therefore \frac{\text { Level }}{10-1000 \mathrm{c} / \mathrm{ft}^{3}}$

Under $10 \mathrm{c} / \mathrm{ft}^{3}$
On-Gits Waste

Pacliage

50 Gallon Drums Filled

With Concrete

Cardboard Cartons

$161+2$

Unit

40

Cu. Fl.

292

78ß].

15,000 sq. ft.

Estimated Acreage Used During Reporting. Period:

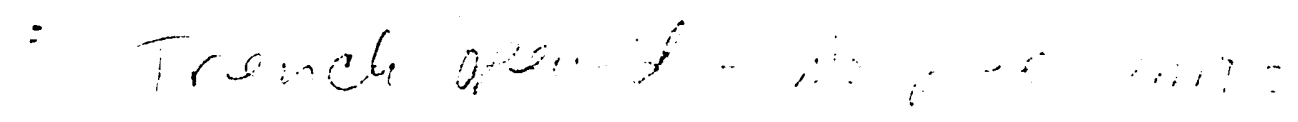

9 
WHC-MR-0416

BURIN L SITE - 300 ire only

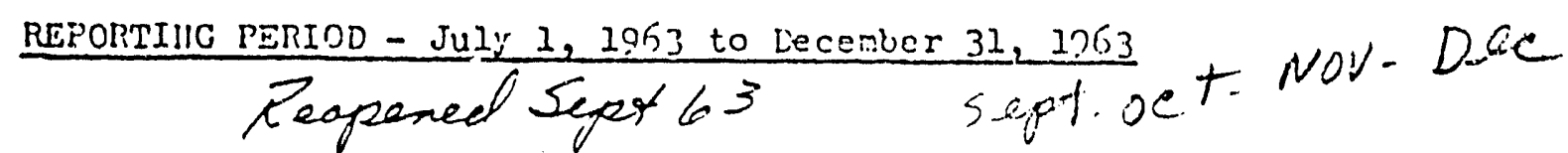

Radioactivity

Level I

Under $10 \mathrm{c} / \mathrm{ft}^{3}$

$10-1000 \mathrm{c} / \mathrm{ft}^{3}$

f $10-1000 \mathrm{c} / \mathrm{rt}^{3}$

* Over $1000 \mathrm{c} / \mathrm{rt}^{3}$
Package

Cardboard Cartons

50 Gallon Drums

StaInless Steel Cans

"Milk Palls"

Stainless Steel Cans

"Catling Guns"
On-Site Waste

UnIt

1660

Cu. Ft.

7470

20

150

151

${ }_{33}, 252$

80

6.075

Estimated Acreage Used During Reporting Period:

4500 sg. rt.

10 


\section{WHC-MR-0416}

BURIAL SI'TE - 300 Hije

\section{REPORTIIC TERIOD - Januar, 1, 1964 to June 30, 1964}

Radionctivity Level

Under $10 \mathrm{cl} / \mathrm{ft}^{3}$

Under $10 \mathrm{Ci} / \mathrm{ft}^{3}$

$10-1000 \mathrm{Cl} / \mathrm{rt}^{3}$

Over $1000 \mathrm{cl} / \mathrm{ft}^{3}$

Preknire

Caraboara Cartons

50 Calion Drums

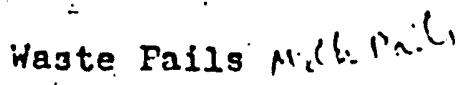

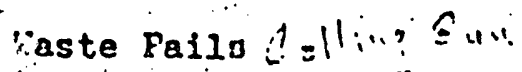

Estimated Area Used During Feportine Feriod:

16,000 s9.rt.

Unit: Cu. Ft.

$3750 \quad 16,875$

$25 \quad 188$

$425.6, \quad 78,163$

150.073

$5,0.973$

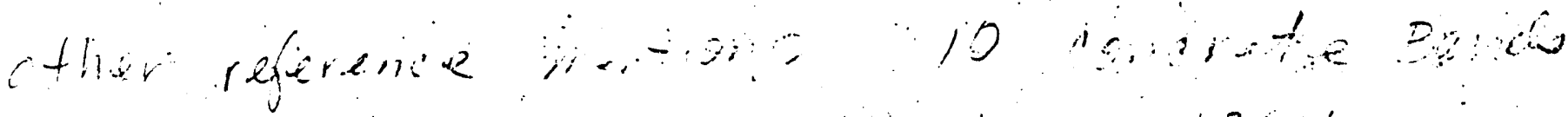
4

NEXT ide

PHO-CD-

ado ir iten

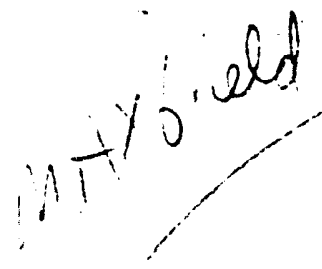

50

July.21, septit $4=$ Now25 $1964 *$

$218-w 4 A$ "Dry wells" acceptef Haiford LAB waite - mosty $327 \mathrm{BI} / \mathrm{g}$ 
WHC-MR-0416

$325 \mathrm{~B} 1 \mathrm{~kg}$ git $=$ Cark truck

$\frac{1}{1}+$

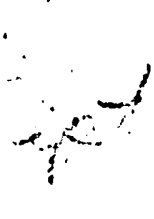

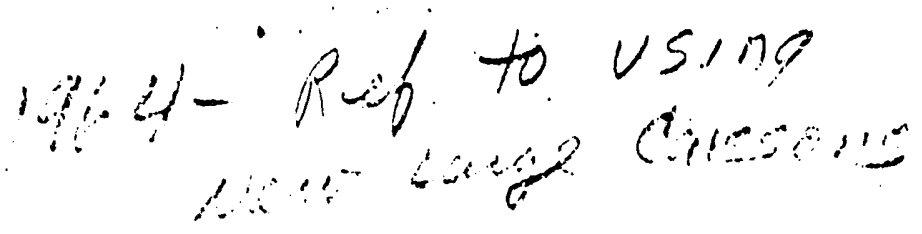

BURIAL SITE - 300- VYE

Reporting Period - July 1, 1964 to December 31, 1964

Radioactivity

Level

Under $10 \mathrm{Ci} / \mathrm{ft}^{3}$

Under $10 \mathrm{Ci} / \mathrm{ft}^{3}$

$10-1,000 \mathrm{ci} / \mathrm{ft}^{3}$

$10-i, 000 \mathrm{CI} / \mathrm{ft}^{3}$

Over $1,000 \mathrm{Ci} / \mathrm{ft}^{3}$
On Site Waste

Package

Unit

4,875 21,937

Cardboard Cartons

50 Gallon Drums

Waste Pails

"Milk Pails"

Waste Pails (5 gal.) $(325 \cdot k)$

Waste Pails

"Gatling Gui:"
16.120

384

23
56 $\begin{array}{rr}21,937 \\ 120 \\ 61 & .159 \\ 15 & \\ 2 & .03257\end{array}$

Cu. Ft.

Estimated Area Used During Reporting Period: 22,000 sq. rt.

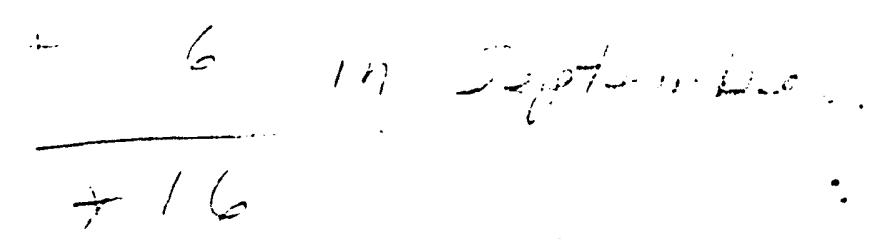

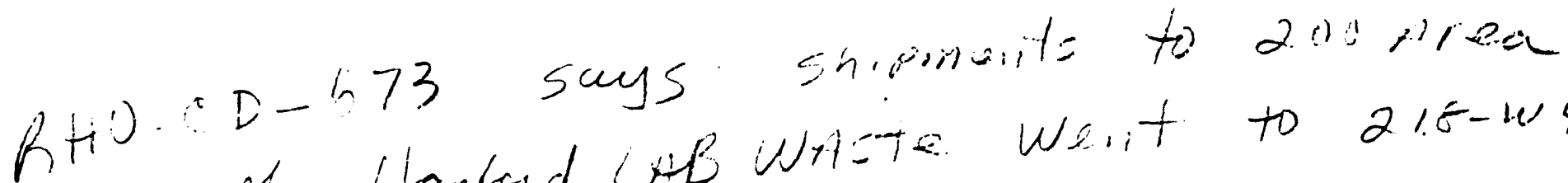

of Hanged LHB Write. Whit to $216-\mathrm{w} 4 \mathrm{H}$ in july, Sept a now 196\%

12 


\section{DPIL EIRE-303-IIE}

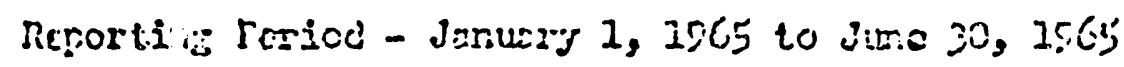

Tiecliosetivlity I.TCI

Trelar $20 \mathrm{ct} / \mathrm{Ft}^{3}$

onder $10 \mathrm{cs} / \mathrm{rt}^{3}$

Uridor $10 \mathrm{cl} / \mathrm{rt}^{3}$

$10-1,000 \mathrm{cl} / \mathrm{ft}^{3}$

$10-1,000 \mathrm{ci} / \mathrm{st}^{3}$

$10-1,000 \mathrm{cL} / \mathrm{ft}^{3}$

over $1,000 \mathrm{ci} / \mathrm{st}^{3}$

\begin{tabular}{|c|c|c|}
\hline 160535 & 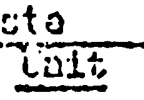 & Ca. \\
\hline Cerciconded Cortola & 1,225 & $19,02 \pi$ \\
\hline Sים & 1,00 & $3,0,0$ \\
\hline Hoojen Crates & 10 & $4: 20$ \\
\hline $\begin{array}{l}\text { Voste Fntls } \\
\text { niilll: } F=1]^{n}\end{array}$ & 420 & 56 \\
\hline
\end{tabular}

iocto feils (9 [3]0) 6

linsto Caris (3 cle. ft.) !:8

$235^{\circ}$

4

215 ?

Fote rolls

"cotlinieg Gu"
$5.5 . \quad 10407$.

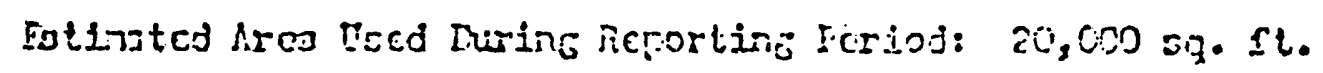


WHC-MR-0416

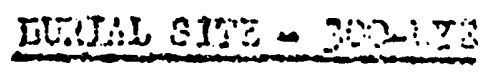

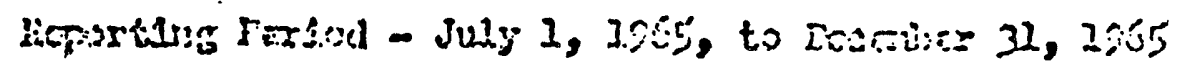

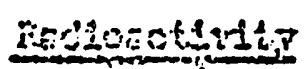

Disis

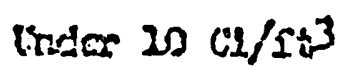

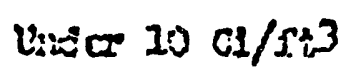

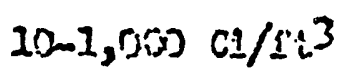

$10-1,050 \mathrm{cL} / \mathrm{s}^{3}$

$10-1,000 \mathrm{cis} / \mathrm{s}^{3}$

Cier $1,00001 / \mathrm{r}^{3}$ $\cos \sin \sin \theta$

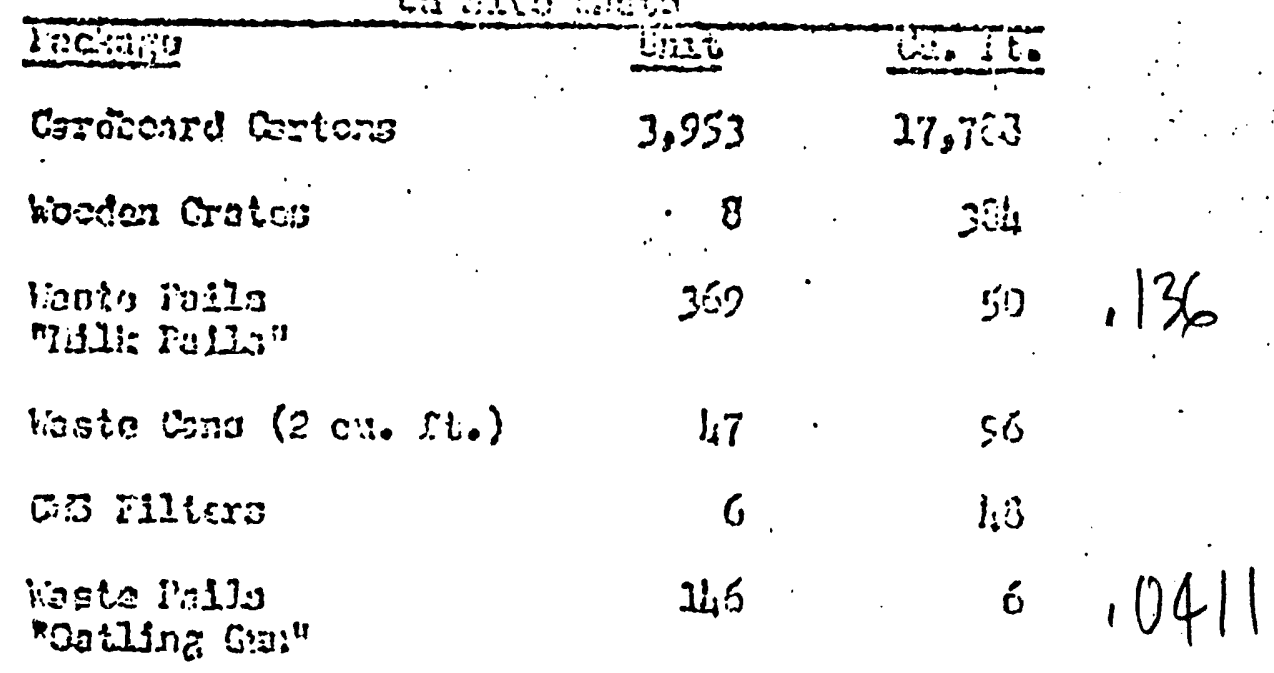

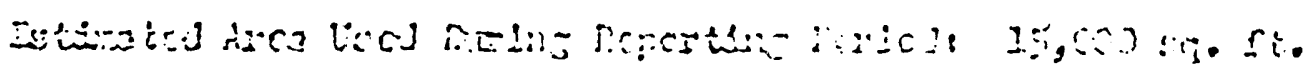

$\frac{y}{1}$

$\therefore$

1.4 
WHC-MR-0416

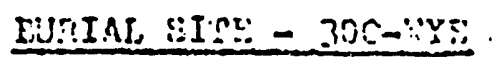

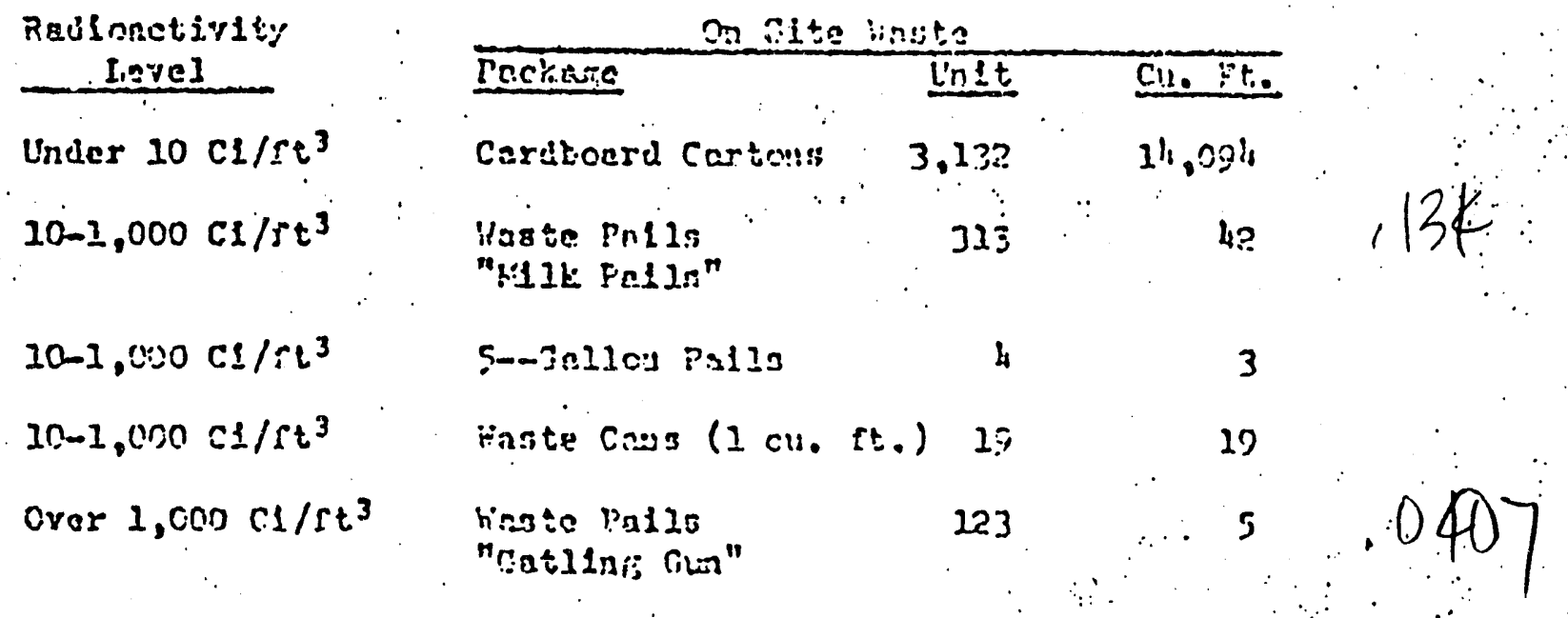

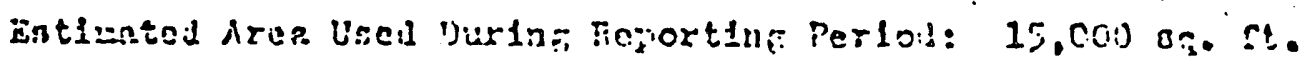

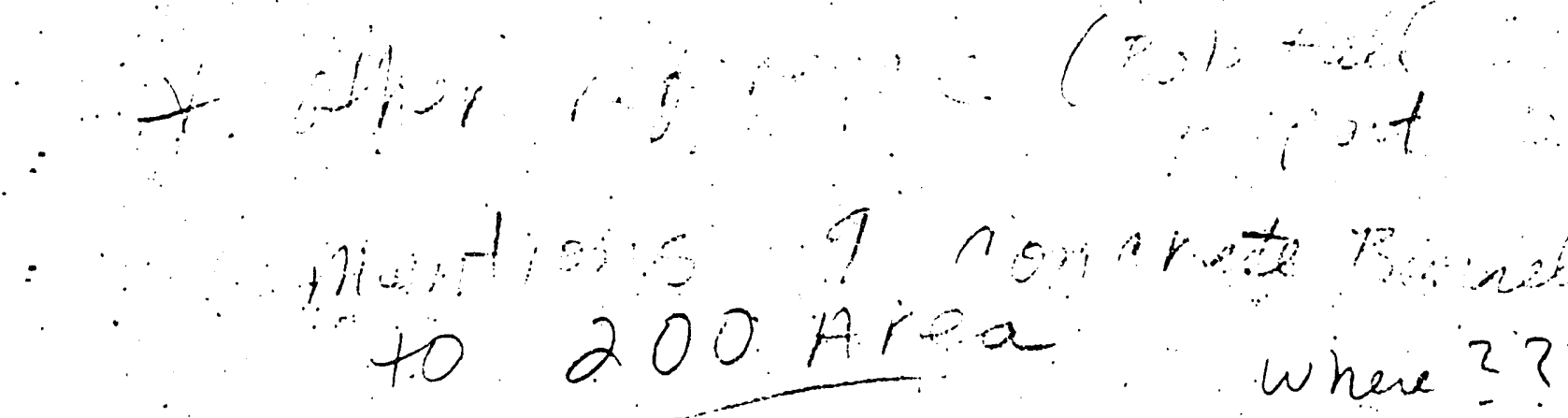
$140^{*}$ ser w4A

15 


\section{WHC-MR-0416}

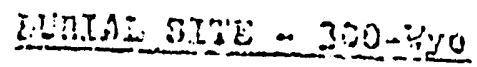

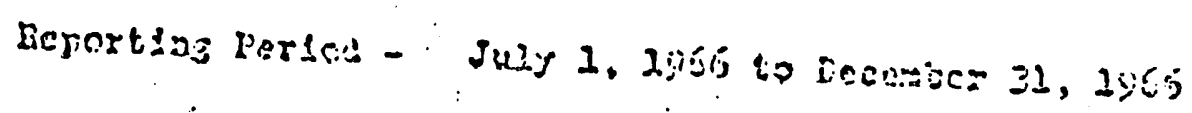

\section{$P=192041014 y$}

Vinder $20 \mathrm{cs} / \mathrm{z}^{3}$

$10-1,000 \mathrm{c} 1 / \mathrm{st} \mathrm{t}^{3}$

$10-2,000 \mathrm{cos} / 5 \mathrm{t}^{3}$

$20-1,0000.1 / 2 t^{3}$

\begin{tabular}{|c|c|c|}
\hline Pagbage. & lings & Cu. IE. \\
\hline CeEdbonrd Cartoras: & 2.213 & 9.503 \\
\hline $\begin{array}{l}\text { Nasta Fulls } \\
\text { "iills ira!ly" }\end{array}$ & $\approx 30$ & 31. \\
\hline 9-3:11en l'allo & 3 & $:$ \\
\hline lingos $\operatorname{cras}(1 \mathrm{cu}, \mathrm{rt})$ & 17 & 17 \\
\hline
\end{tabular}

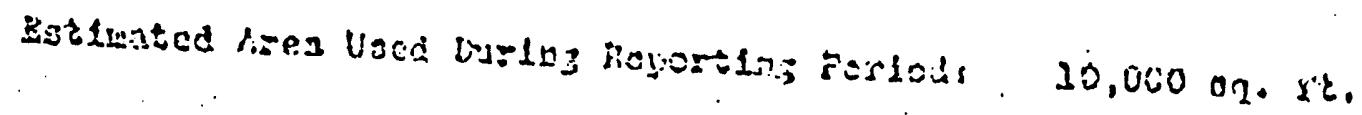


$\therefore$. Report1rs Perlod - January 2, 2906 to Jure 30,1917

Radionctivity Lovel

Estimated arca used during regortinë perlod: 12,000 en. rt.
Under $10 \mathrm{cl} / \mathrm{rt}^{3}$
$10-1,000 \mathrm{cl} / \mathrm{rt}^{3}$
$10-1,000 \mathrm{cl} / \mathrm{rt}^{3}$
$10-1,000 \mathrm{ci} / \mathrm{st}^{3}$
On Site luste

\begin{tabular}{|c|c|c|c|}
\hline Paclense & Un1t & Cu. Fl. & \\
\hline Cardboard Curtons & $2 ; 300$ & 12,600 & \\
\hline $\begin{array}{l}\text { linste Palls } \\
\text { "ild1ir Follo" }\end{array}$ & 433 & 60 & , \\
\hline 5afialion Bas10 & $\ddot{0}$ & 4 & \\
\hline Haste Cans (1 cu. & (t.) & 5 & \\
\hline
\end{tabular}


WHC-MR-0416

EURILI SI'AE - 300-KXE

Reportiniz Poxicd - iuly 1, 1967 to vecenber 31. 1967

Rad1orctsvity

Level

Undior $10 \mathrm{Cl}^{2} \mathrm{st}^{3}$

$10-2,000 \mathrm{cl} / \mathrm{st}^{3}$

$10-1.000 \mathrm{Cl} / 2 \mathrm{t}^{3}$

$20-1.000 \mathrm{cs} / \mathrm{rt}^{3}$
On silte bia:to

Eicionge

linit

Cardborra Cartonb

3311

Worte Palla

370

"illik Palls"

5-pollon Feilla 40

linsts Cons (1 cu. [t.) 3]
Cu. Ft.

1!: 9000

1.9132

27

33
$=$

- 
SURVEYS THAT REFERENCE PLUTONIUM WASTE BURIAL

$3-29-62$

Survey of equipment wrapped in plastic that had been removed from a grossly contaminated PU hood (from 325, doesn't say where it is going)

$8-3-62$

Load and dump 4 PU WASTE BARRELS to WYE $100 \mathrm{mr} / \mathrm{hr}$

$8-15-62$

Disposal of 2 gloveboxes grossly contaminate with PU no dose rate $(20,000 \mathrm{c} / \mathrm{m})$ from 325 - doesn't say where it is going)

$3-6-63$

PU bottles from $308 \mathrm{Bld}$. in cement leaving $325 \mathrm{BLDG}$ to burial (doesnt say where it is going) $<6 \mathrm{mr} / \mathrm{hr}$

$7-3-63$

Cement Barrels from 325 to 300 North BG $35 \mathrm{mr} / \mathrm{hr}$

8-19-63

PU solution in glass bottle and PU solution in plastic bottle from 325 to burial (doesn't say where) $2500 \mathrm{c} / \mathrm{m}$

$11-3-65$

Boxed PU waste in load lugger fro $325 \mathrm{~A}$ to WYE 


\section{WHC-MR-0416}

SURVEYS THAT REFERENCE 200 AREA BURIALS

$3-13-6 ?$

5 cans of PU waste to 2O2-S(REDOX) on RSR

$8-10-62$

Survey of 4.59 grams (or $458 \mathrm{~g}$-hard to read) in carton for shipment to 200 West Burial on RSR $<6 \mathrm{mr} / \mathrm{hr}$

$1-10-63$

Cardboard ice cream carton containing 300 grams of solid PU waste from 325 to $234-5.10 \mathrm{mr} / \mathrm{hr}$

$1-16-63$

5 five gal. cans of PU solution from 325 to $202-\mathrm{s}(5 \mathrm{mr} / \mathrm{hr})$

$7-11-63$

2 garbage cans containing PU solution in poly bottles sealed in plastic. $30 \mathrm{mr} / \mathrm{hr}$ from 325 to PUREX

$9-8-67$

Load PU waste in lugger and liquid waste on flatbed dump for transfer to 200 area burial (from 325) 5-15 mr/hr on boxes $\max .50 \mathrm{mr} / \mathrm{hr}$ on barrels. 


\section{WHC-MR-0416}

\section{8-11. BURIAL GROUND}

HISTORY OF USE

a SERVICE DATES Z/E? - 22/67

- RADiofllCLIDE CONTENT

TOTAL BETA/GAMMA $=22000 \mathrm{CI}$

TOTAL PER $=1$ TO $10 \mathrm{KG}$

- disposal form

LOH LE!EL DRY WASTE II THREE TRENCHES

MODERATE TO HIGH LEVEL DPY HASTE BiA 50 VERTICAL PIPE UNITS AND 4 CAISSCIIS

- CUSTODY TRANISFERRED TO ARHCO IN JANUARY 1972

- FEMCE IMSTALLED IN SEPTElBER 1974 (PREVIOLOS TO FEICIMG,

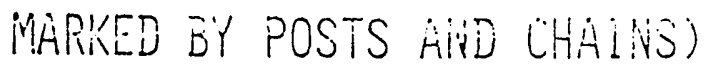

- PADTAEDN MONITORENG RECALLS INCIDEIT OF PERSONHEL FOUMD WAOERTH OH BURIAL GROUVE WHICH OCCURRED PRIOR TO FENINIS

- ALL RECORDS OF RADIATIOM POIITORIIU SURVEYS (1973 - 1931)

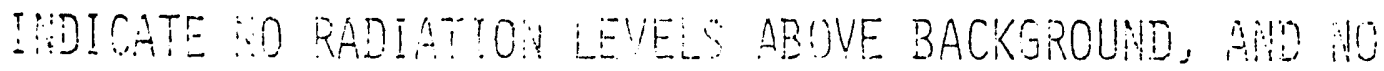
SUREACE CONTAMINATICH EXCEPT A SINGLE TUMBLENEED WITH $400 \mathrm{CP}$ il

- MOST RECENT SURVEY REVEALED SITE PERIMETER RADIATION LEVELS OF 200 CPM WITH GH AHD O R R/HR WITH MICROROENTGEM UETER 

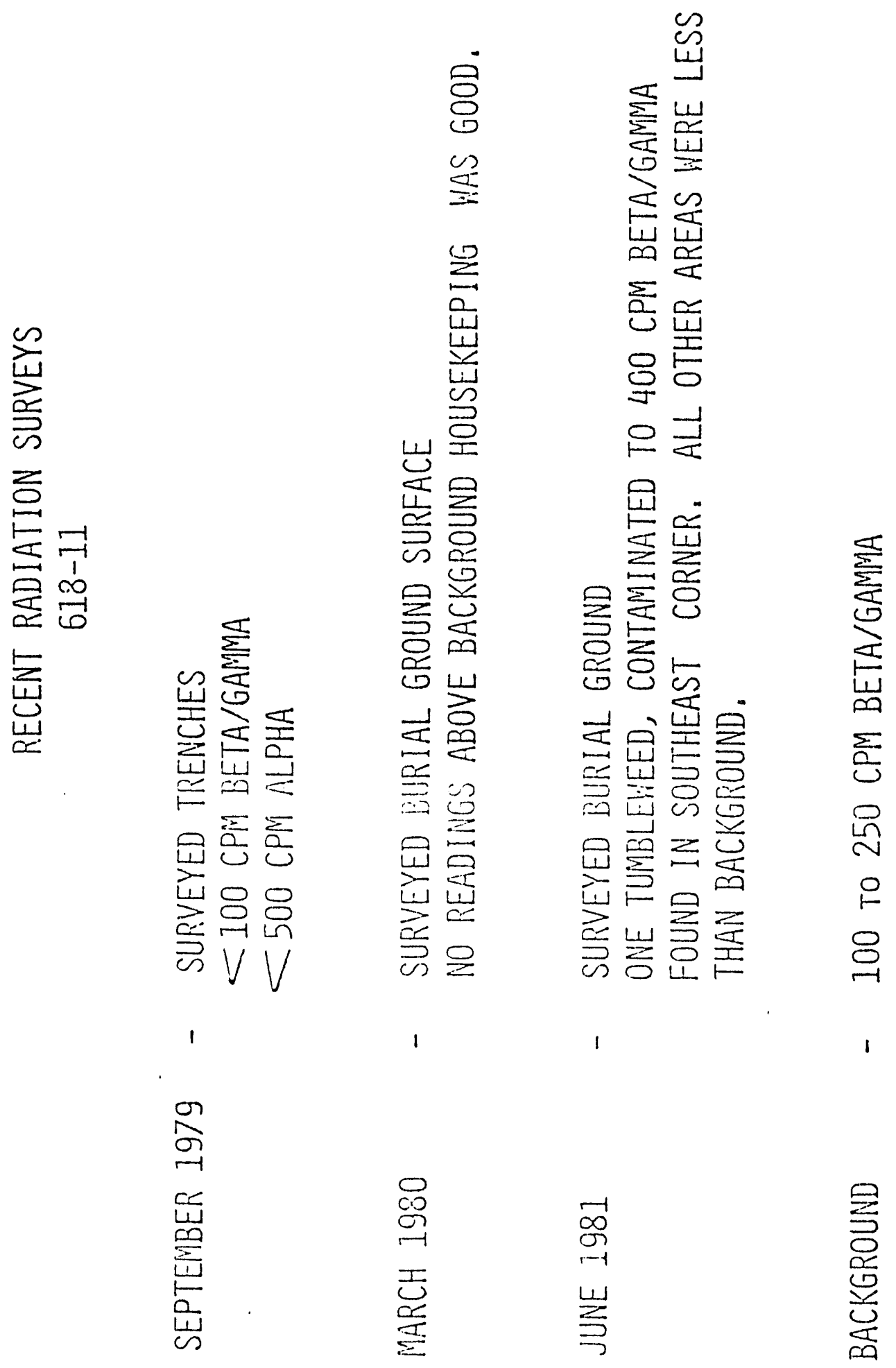


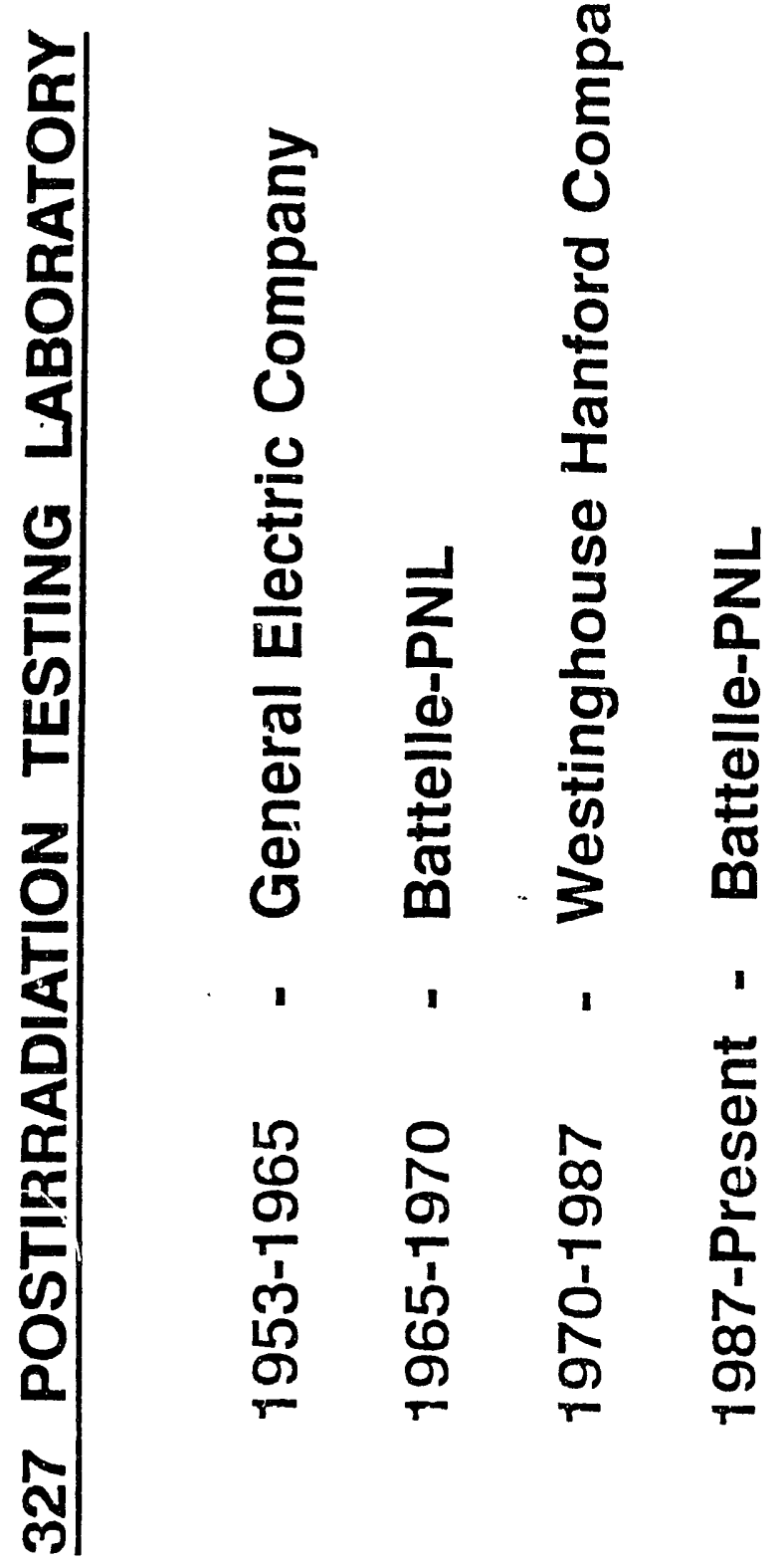



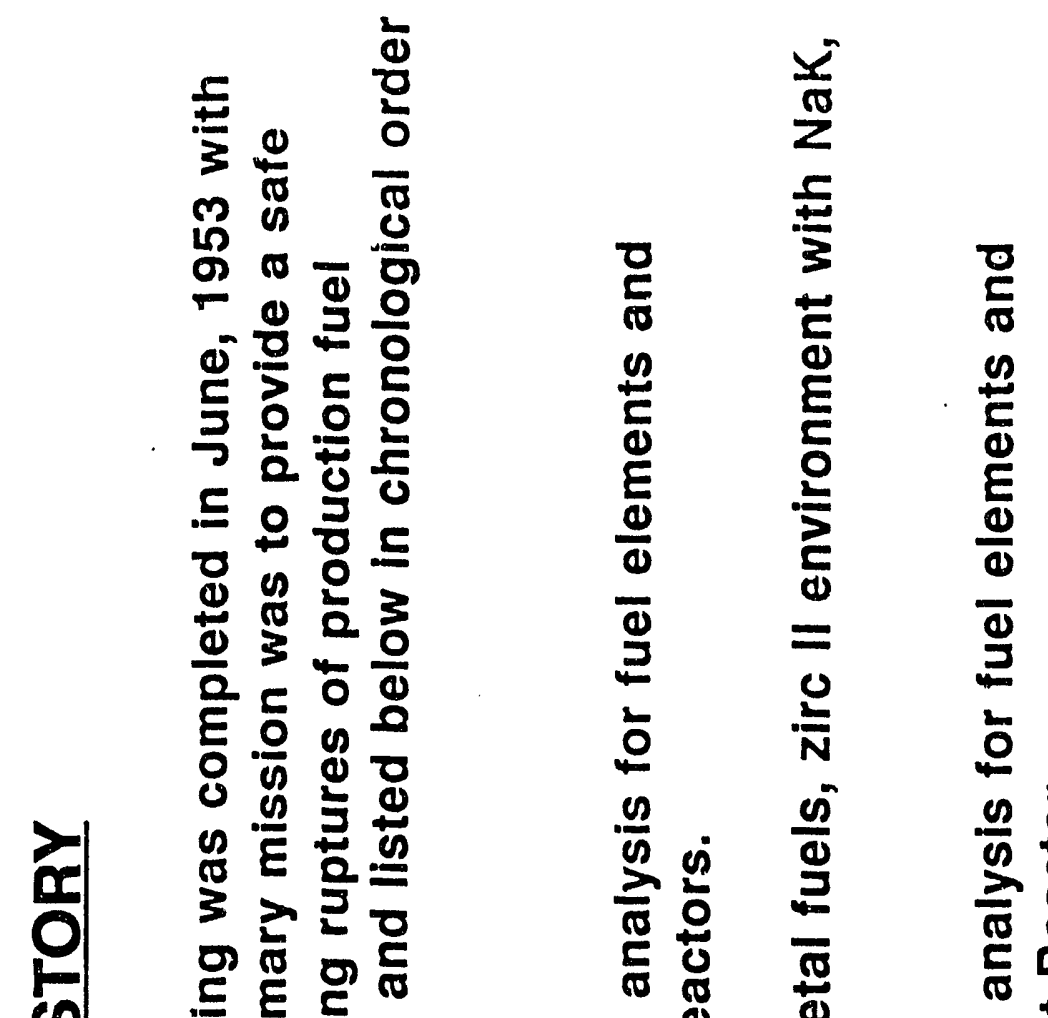

를 응 웅

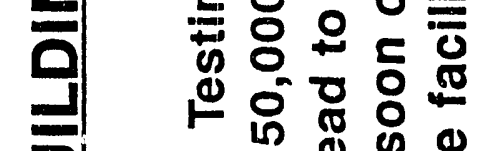

핀

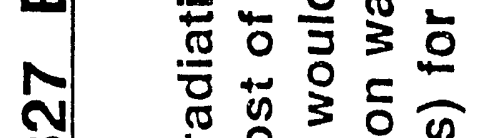

N 논

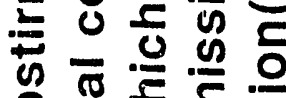

क $\frac{\pi}{5}$ ह $\frac{1}{3}$

$2=3 \%$

入도

인 등 을 을

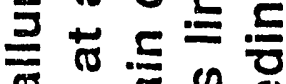

एक

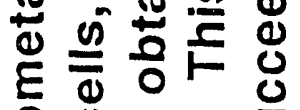

ह $0 \begin{array}{lll}0 & 0 & 0 \\ 0 & 0 & 0\end{array}$

응 웅

몬

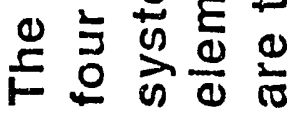

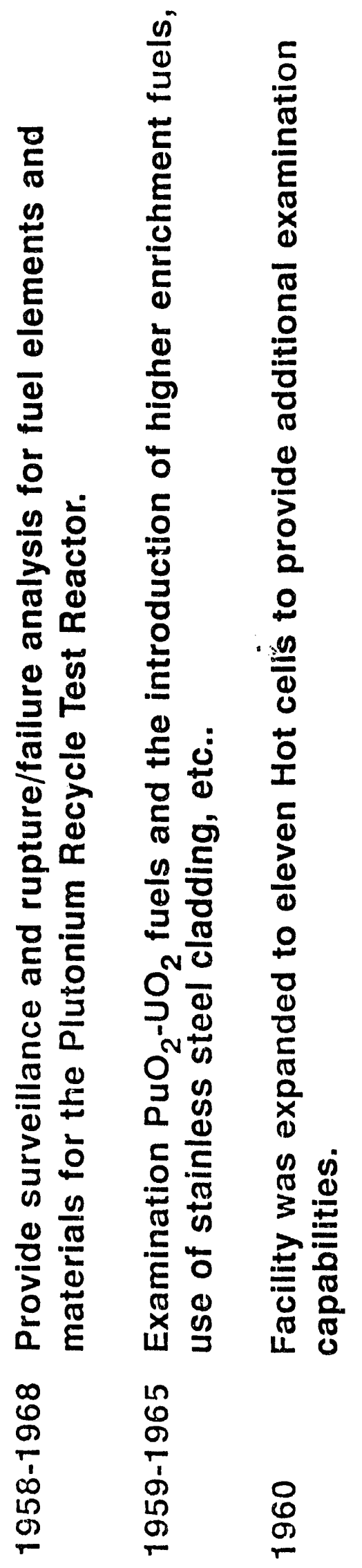




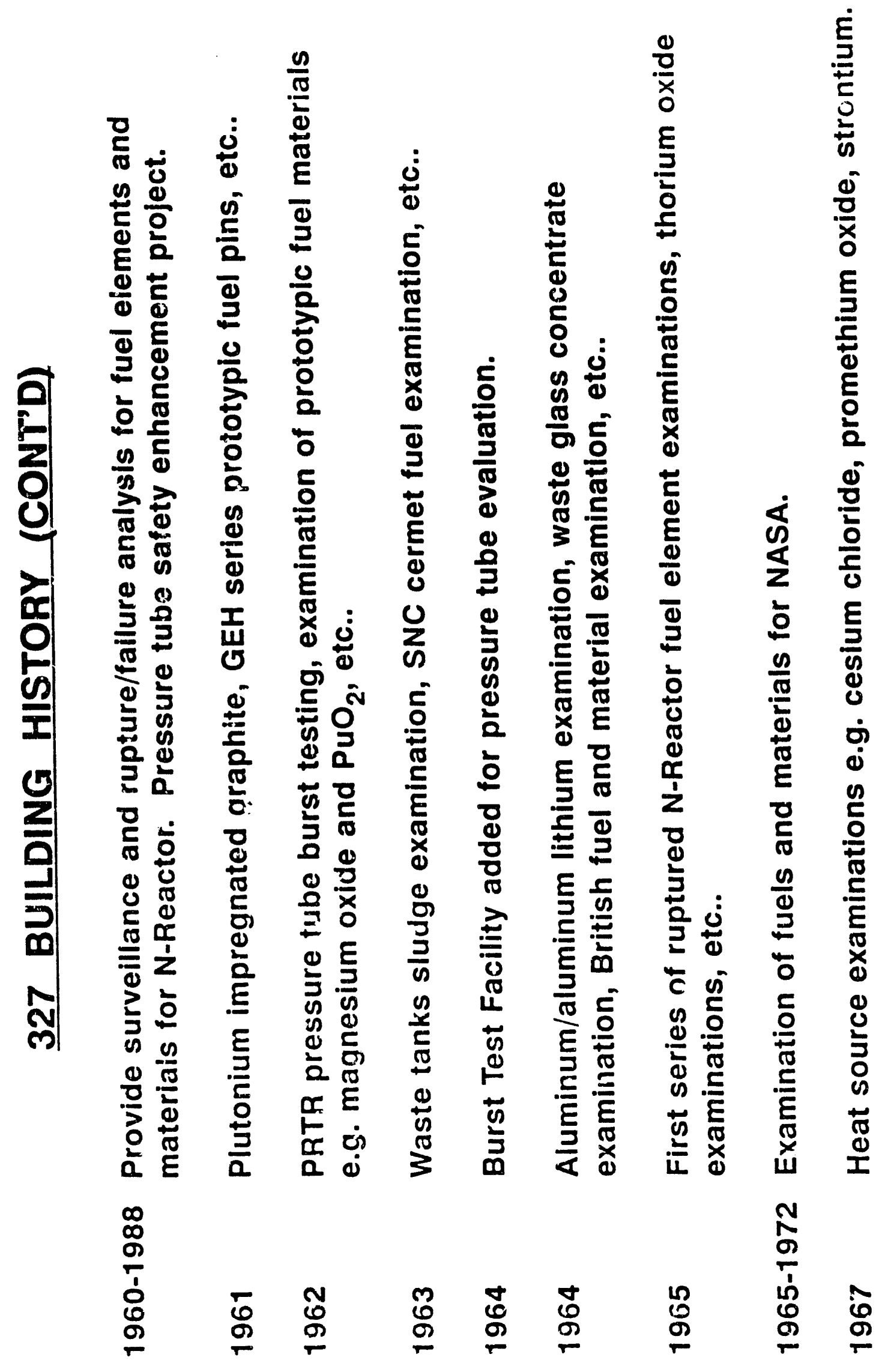


WHC-MR-0416

18q-E

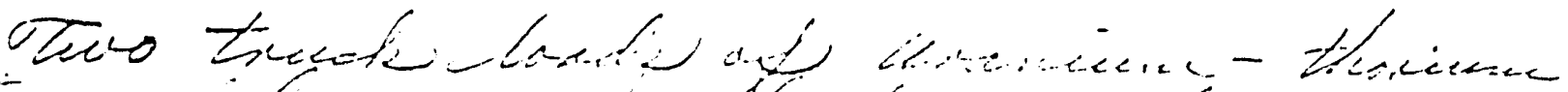

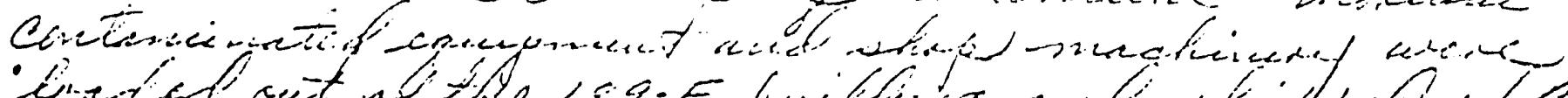

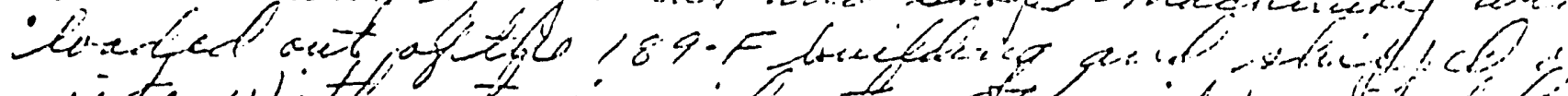

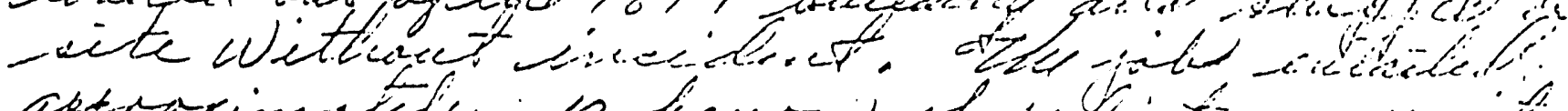

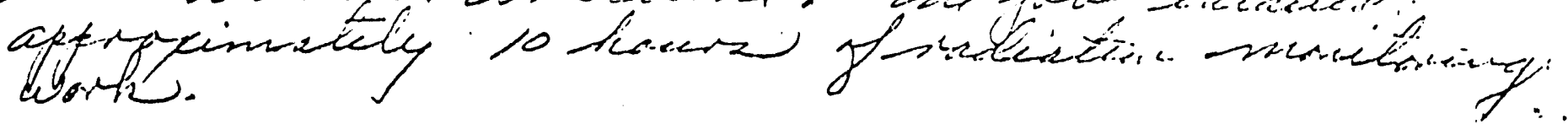

HoO cl.eer.

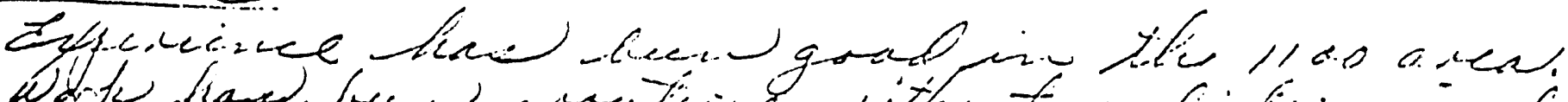

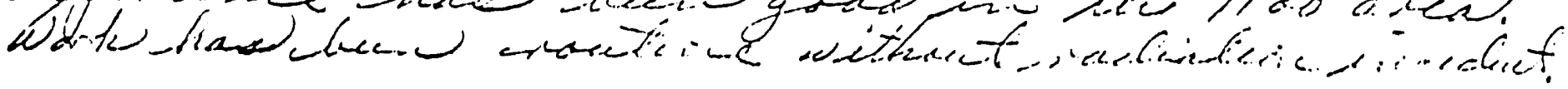

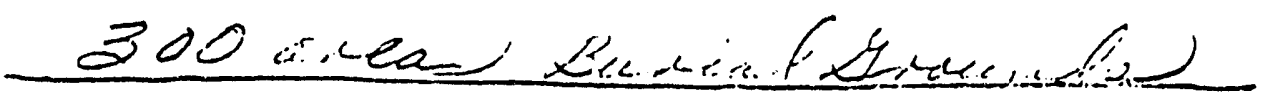

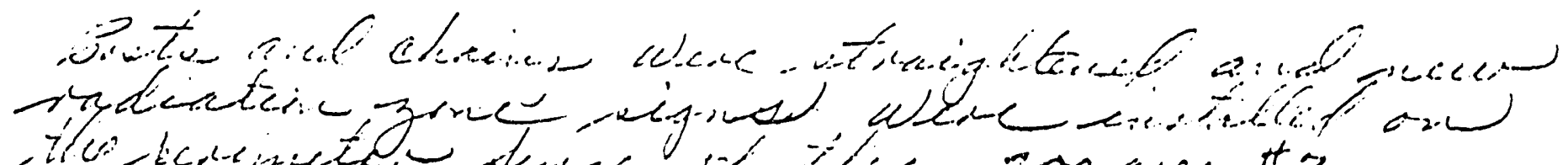

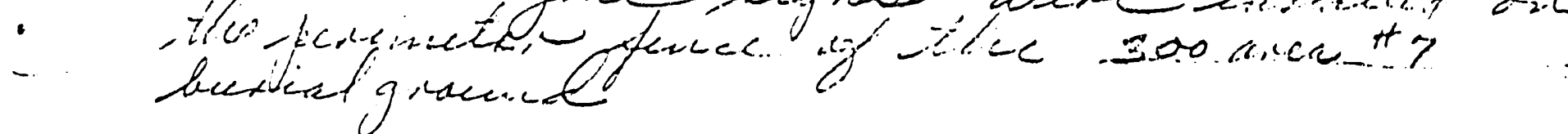
buxiticigracende $-\ldots$

iv

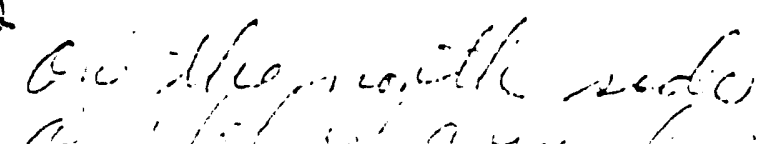
"У"

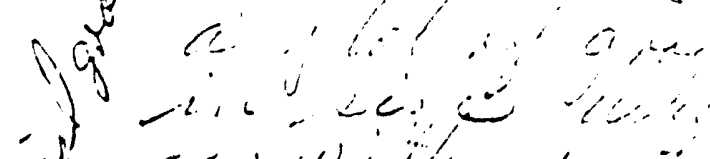
$=0-1$,

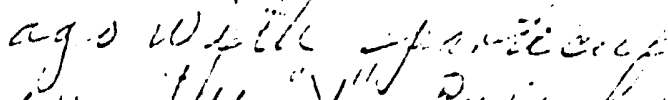

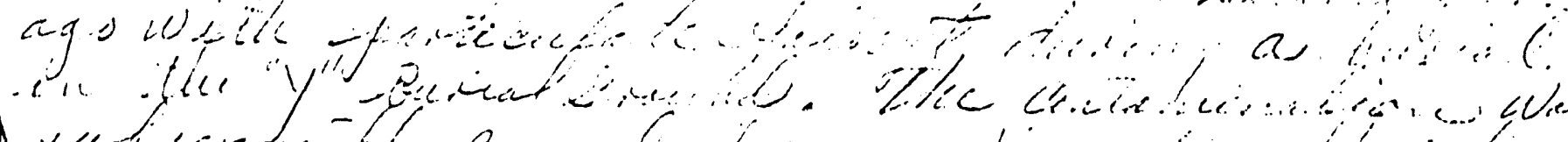

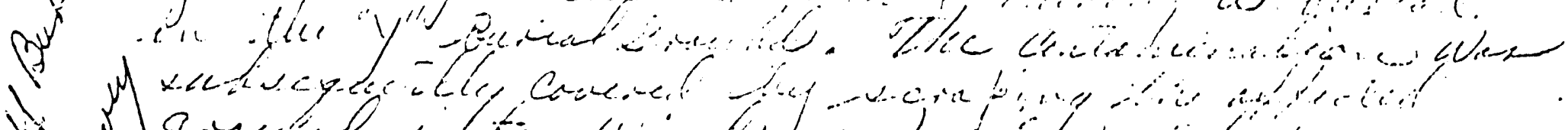

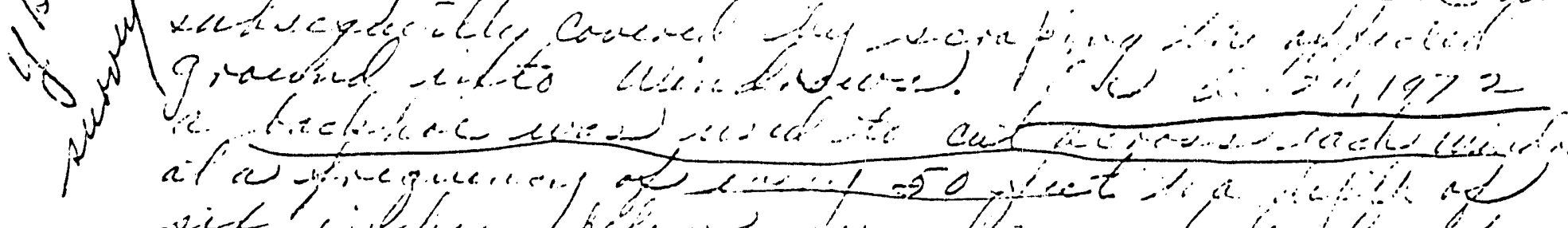

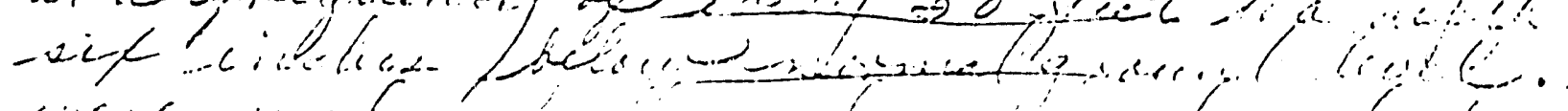
-r.?., $11: 0, C_{c}$

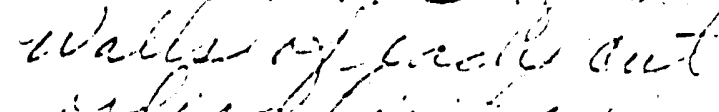

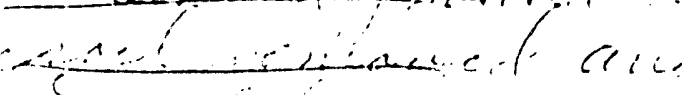

$$
-
$$




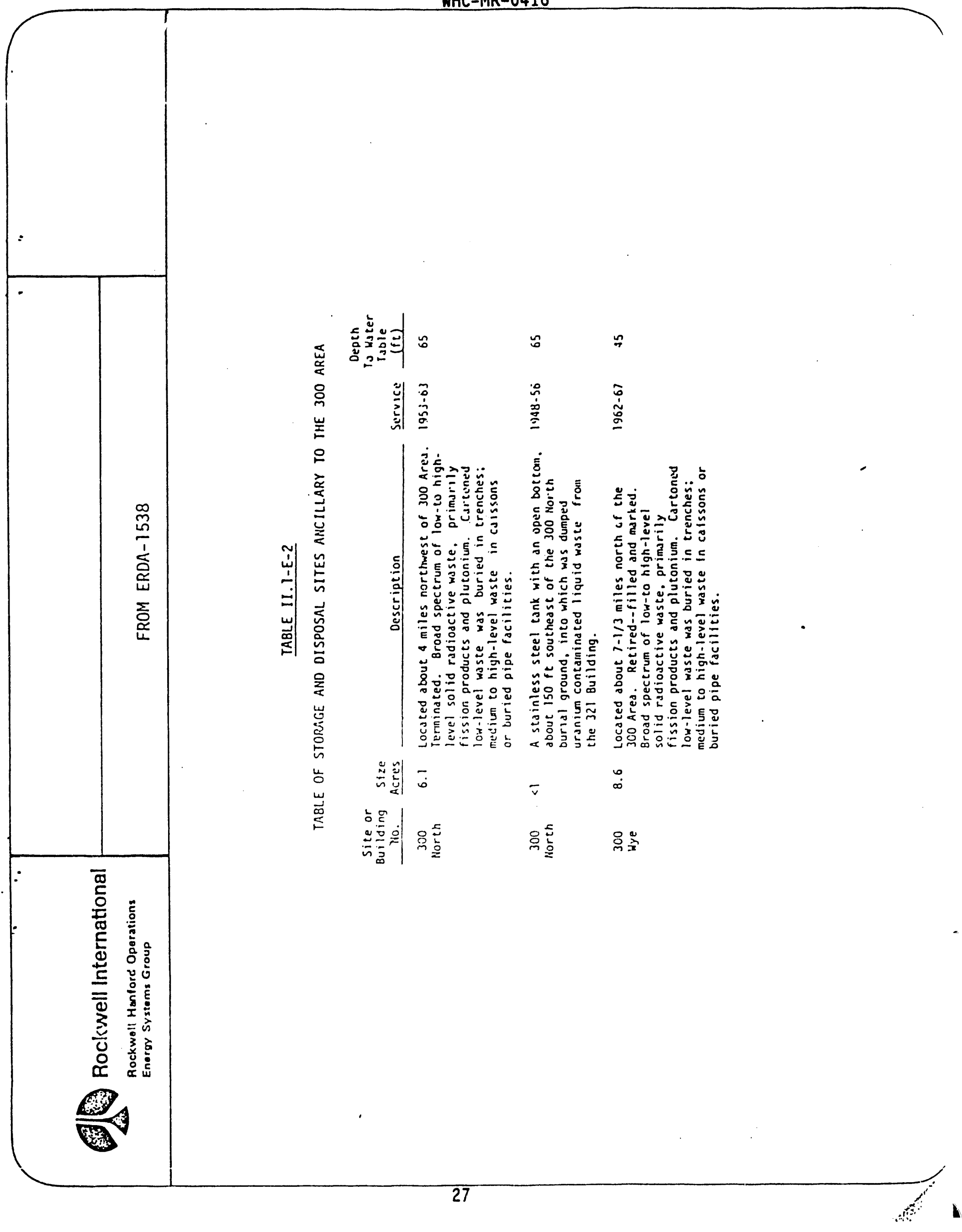


WHC-MR-0416

6/8-11 Lawnit hy wepss explyes 1982.83?

62.67

$2,000 \mathrm{G} \quad L U-3$ thencls M to HLd 50 Pige arts +4 cissors

72. to Arhico

14 .. fenced.

up to $10 \mathrm{~kg}$ fu -records bost in 65 Els $-2 \mathrm{ks}$

618.5 aly 1 fort cles soil ower curkowe

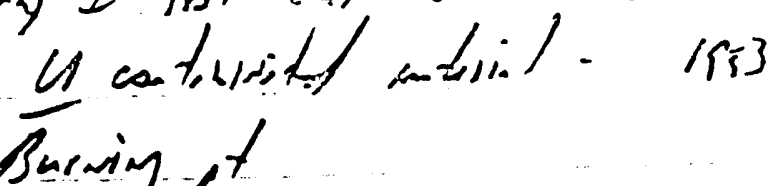

6187 pit $20 \times 140$ Cl in solvat Latu/s $3216 / 1 / 5$

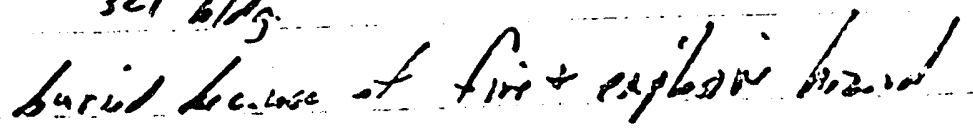

28 


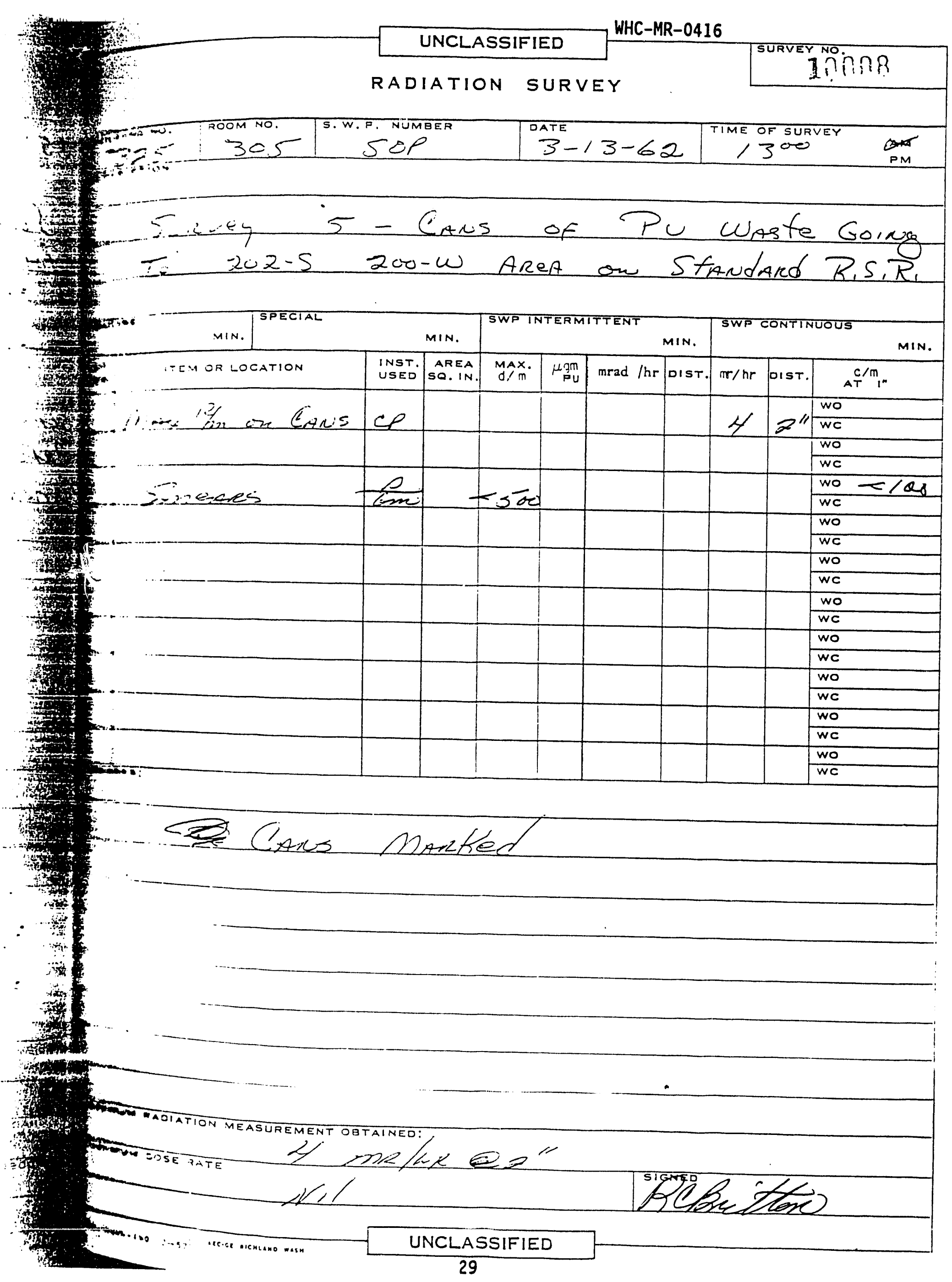




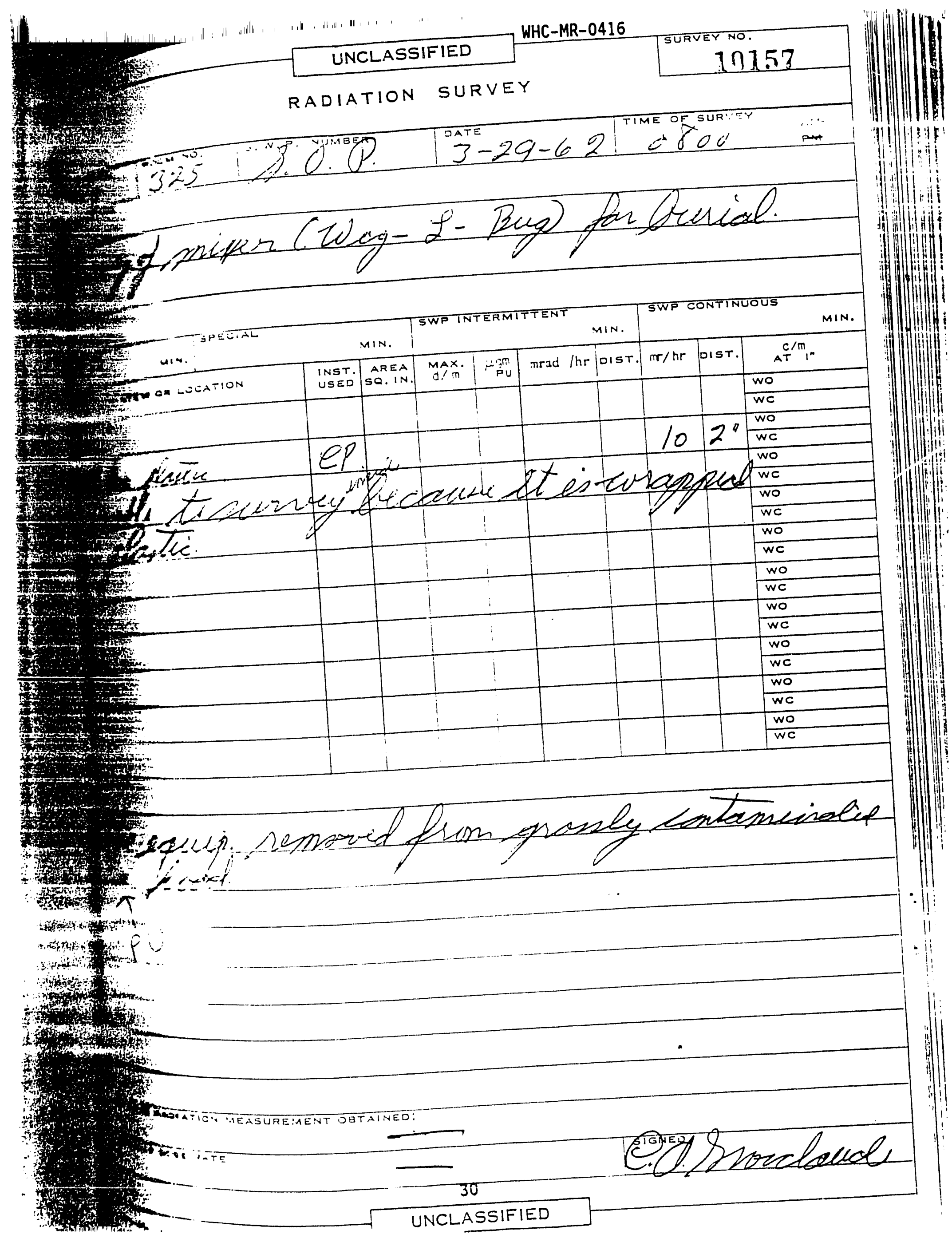


WHC-MR-0416

UNCLASSIFIED

RADIATION SURVEY

10.255

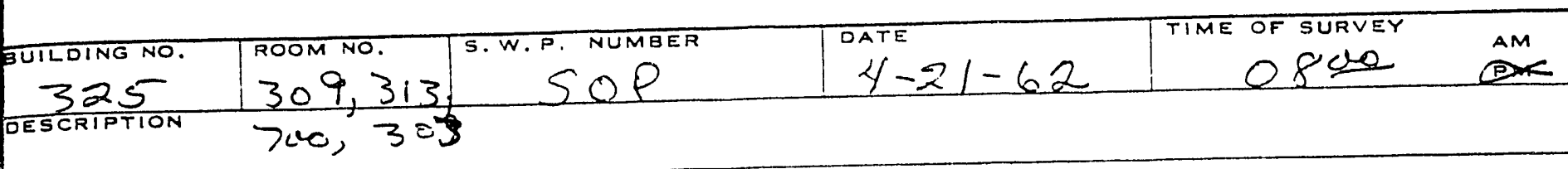

To Monitor Fin Anslitiend Fersomel To

Run Analysis an (criticality, Solution

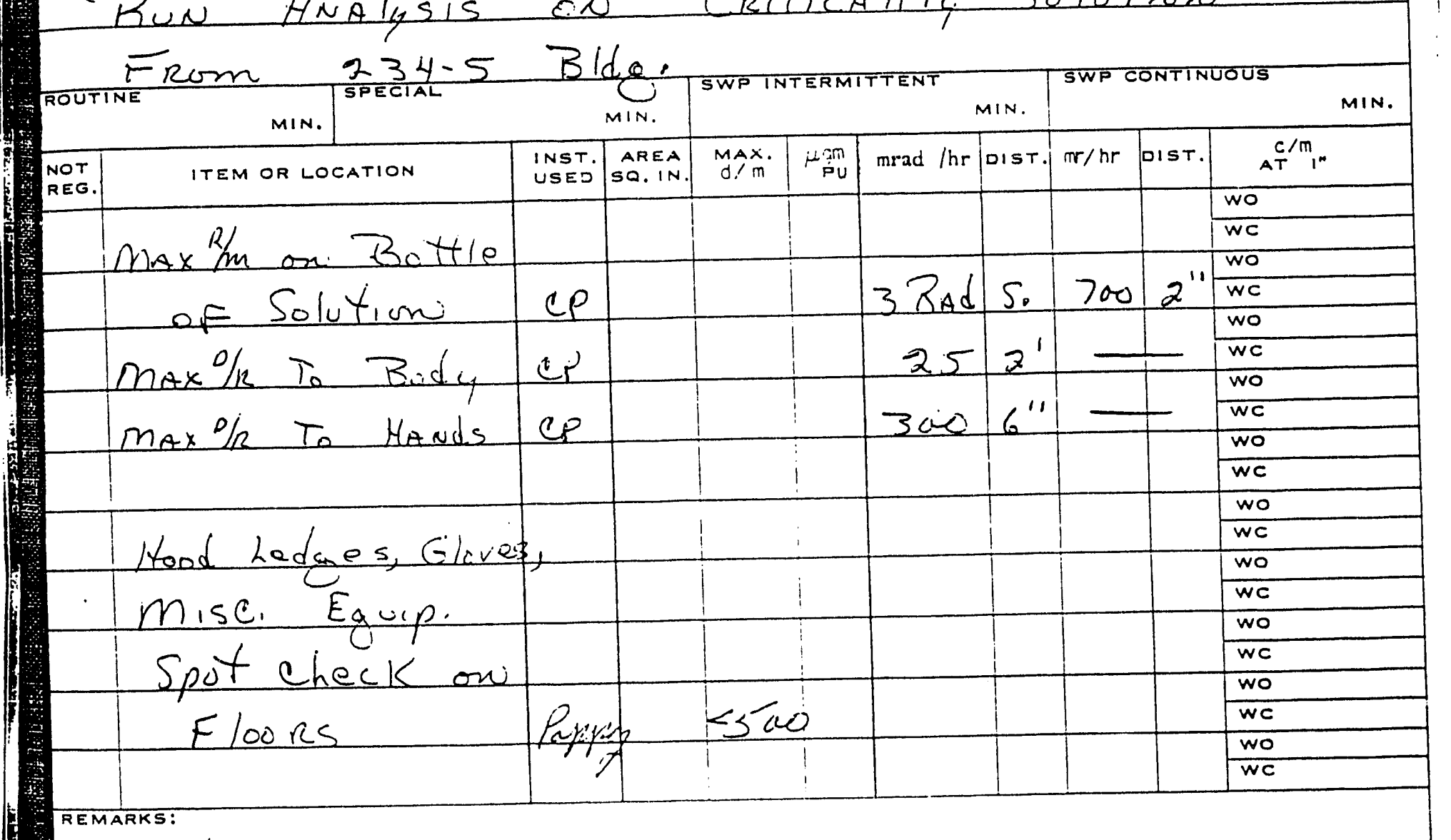

Est. Figures Given wins About 34 breams of Pl , ter lesion.

MAXIMUM RADIATION MEASUREMENT DBTYNEDD:

3 Rad thu le S, well. 700 sphere @ $2 "$

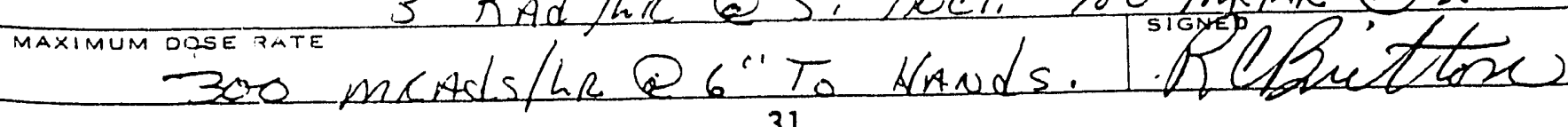

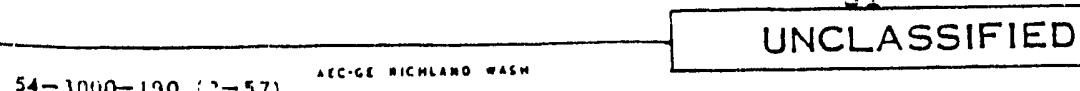




\section{RADIATION SURVEY}

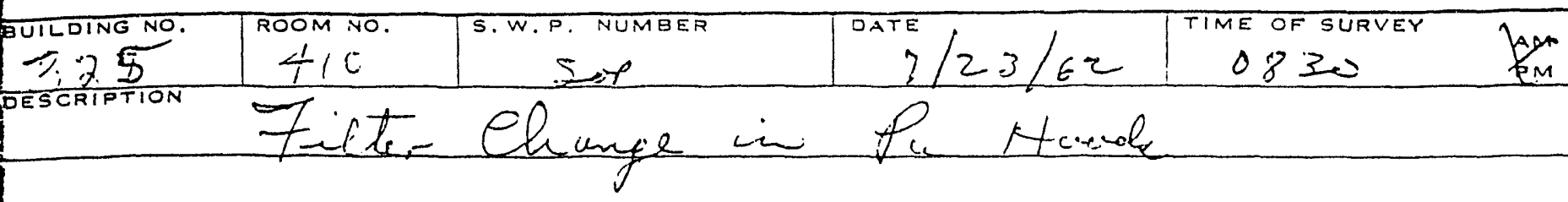

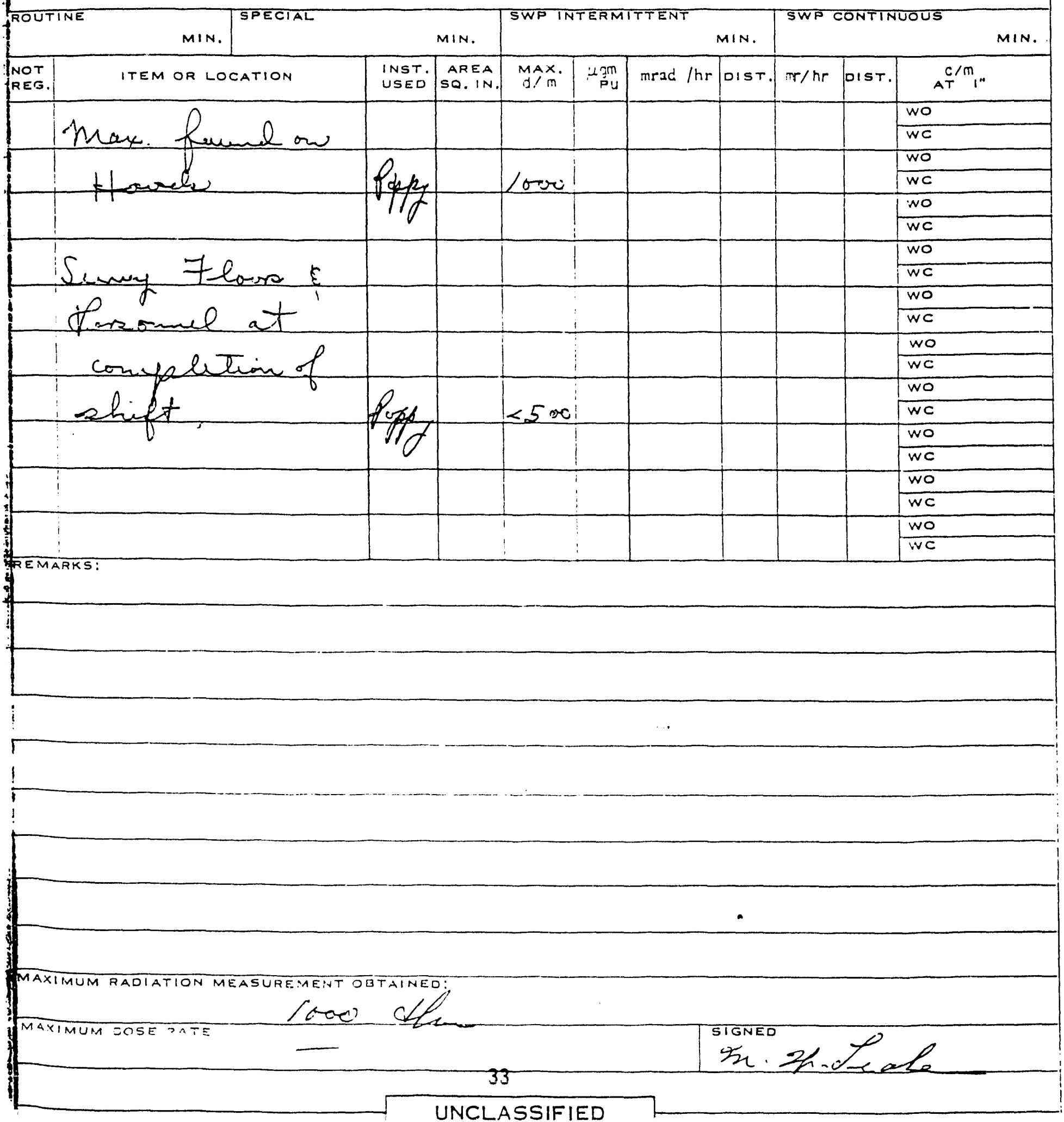




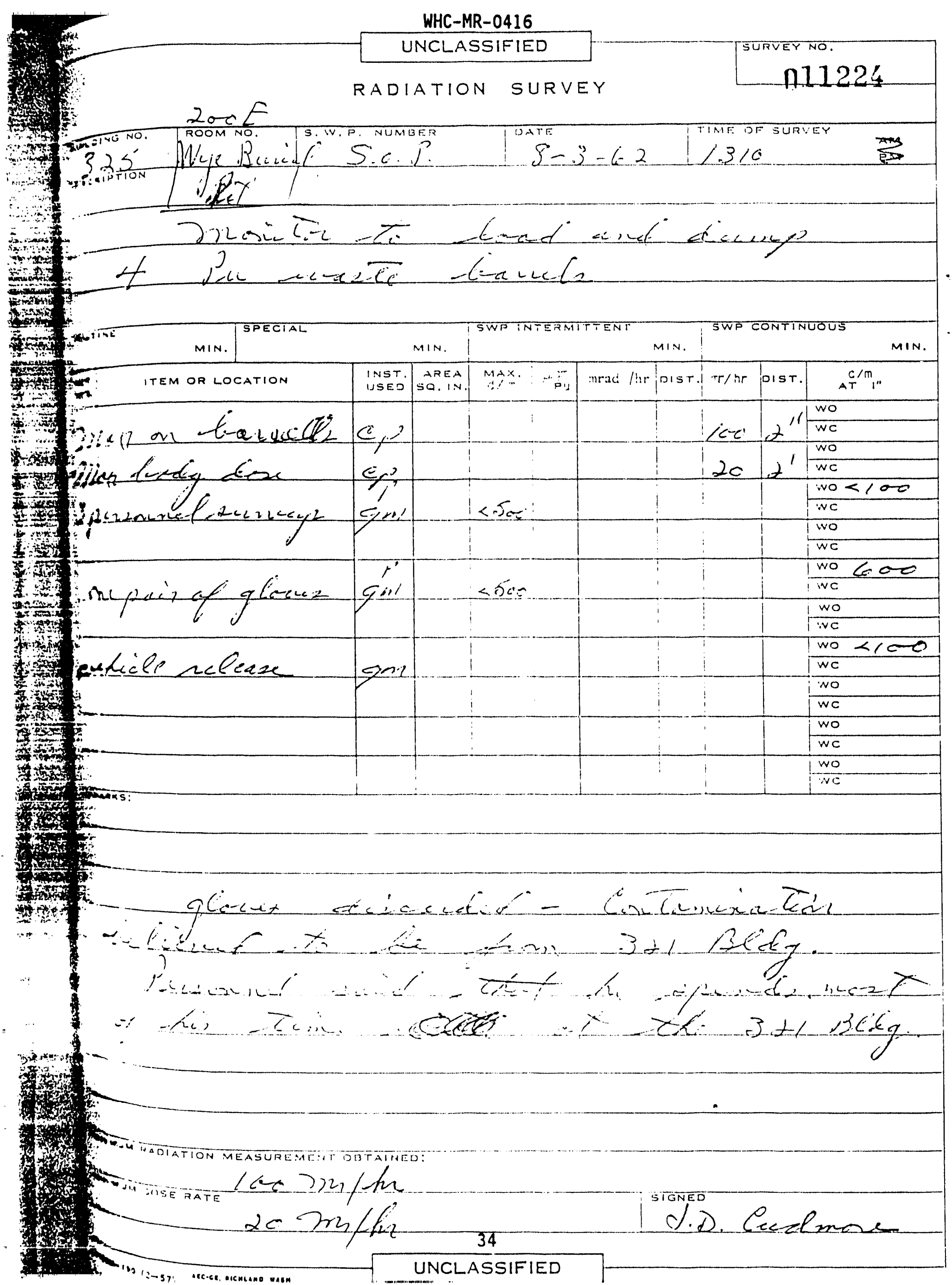




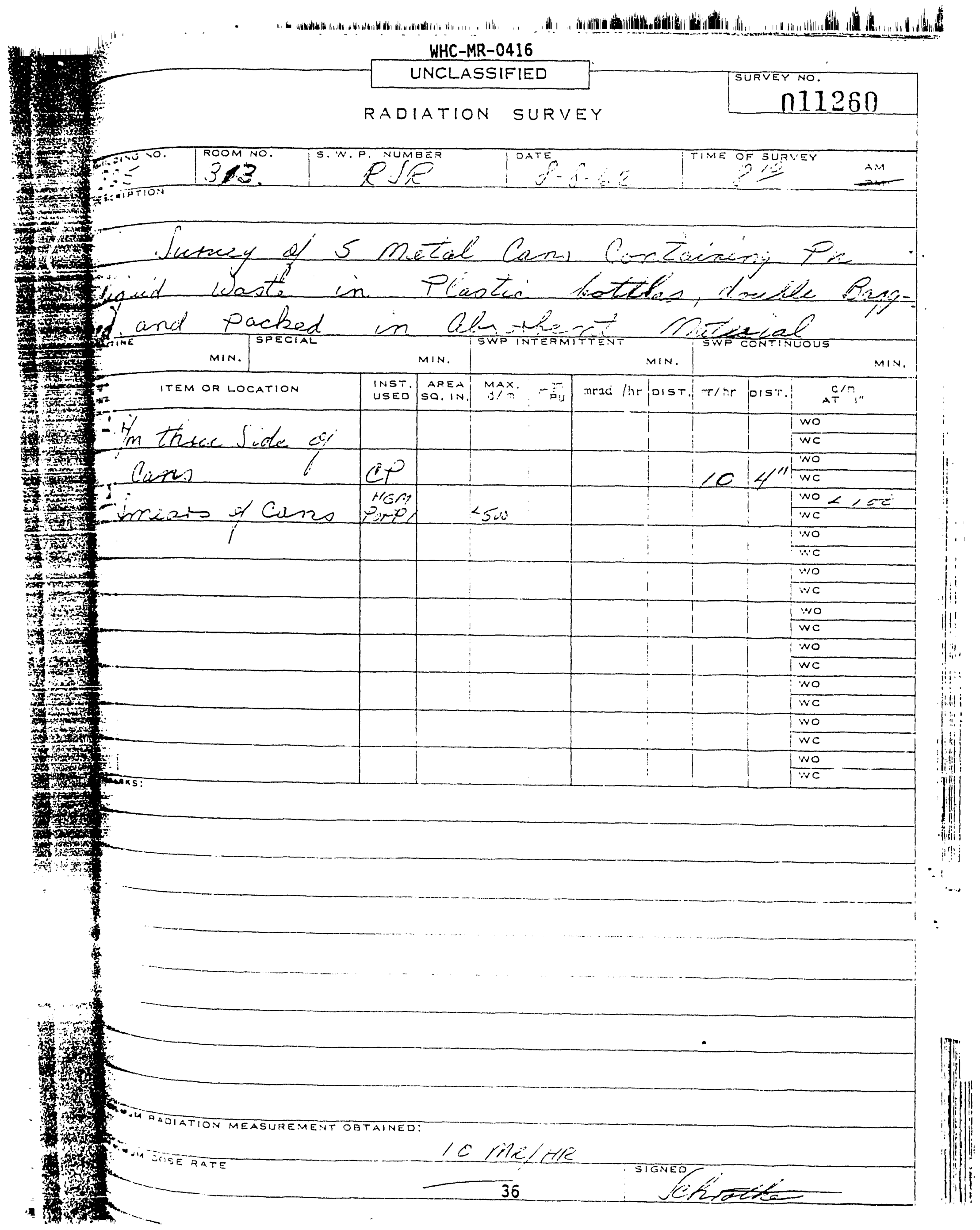




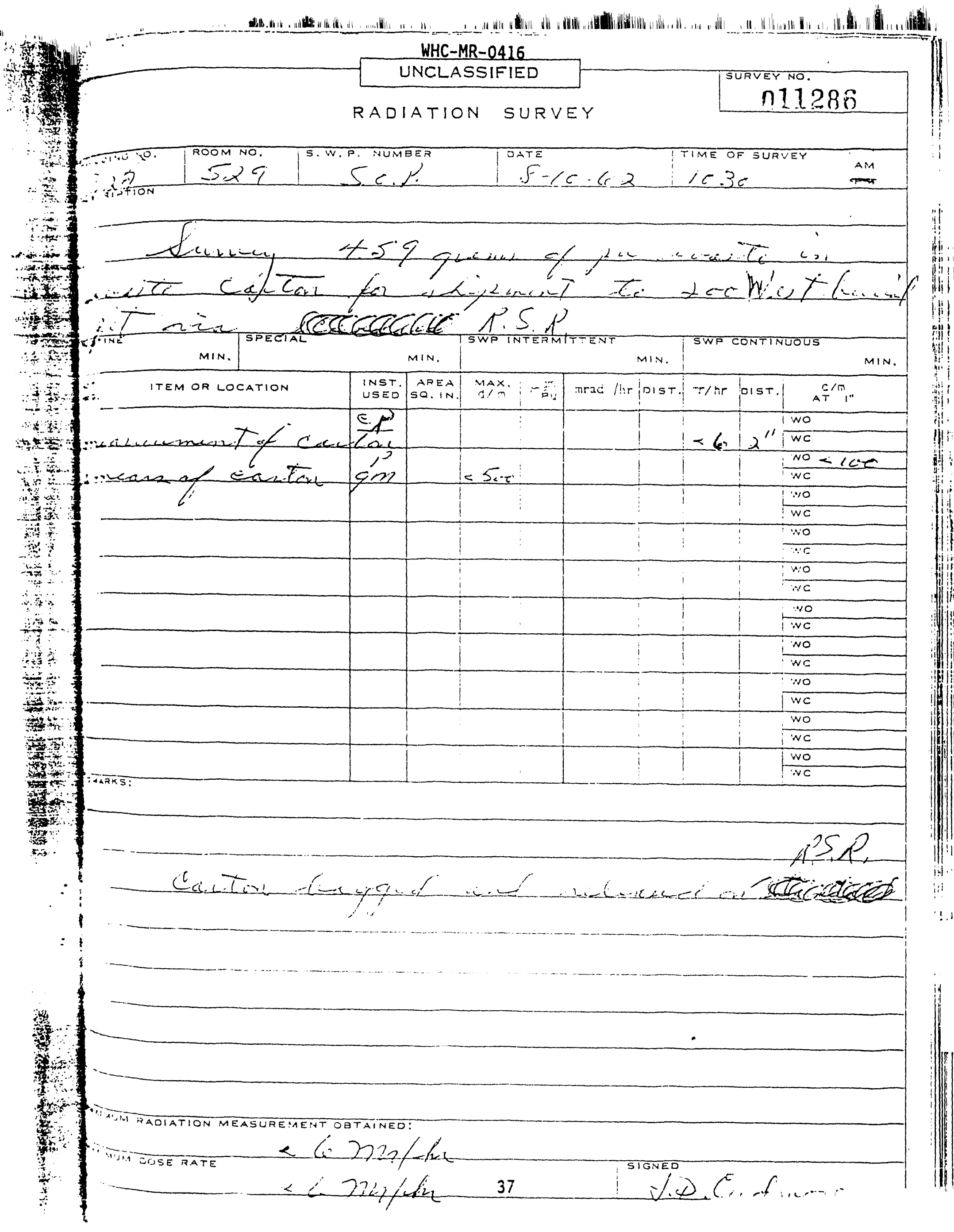




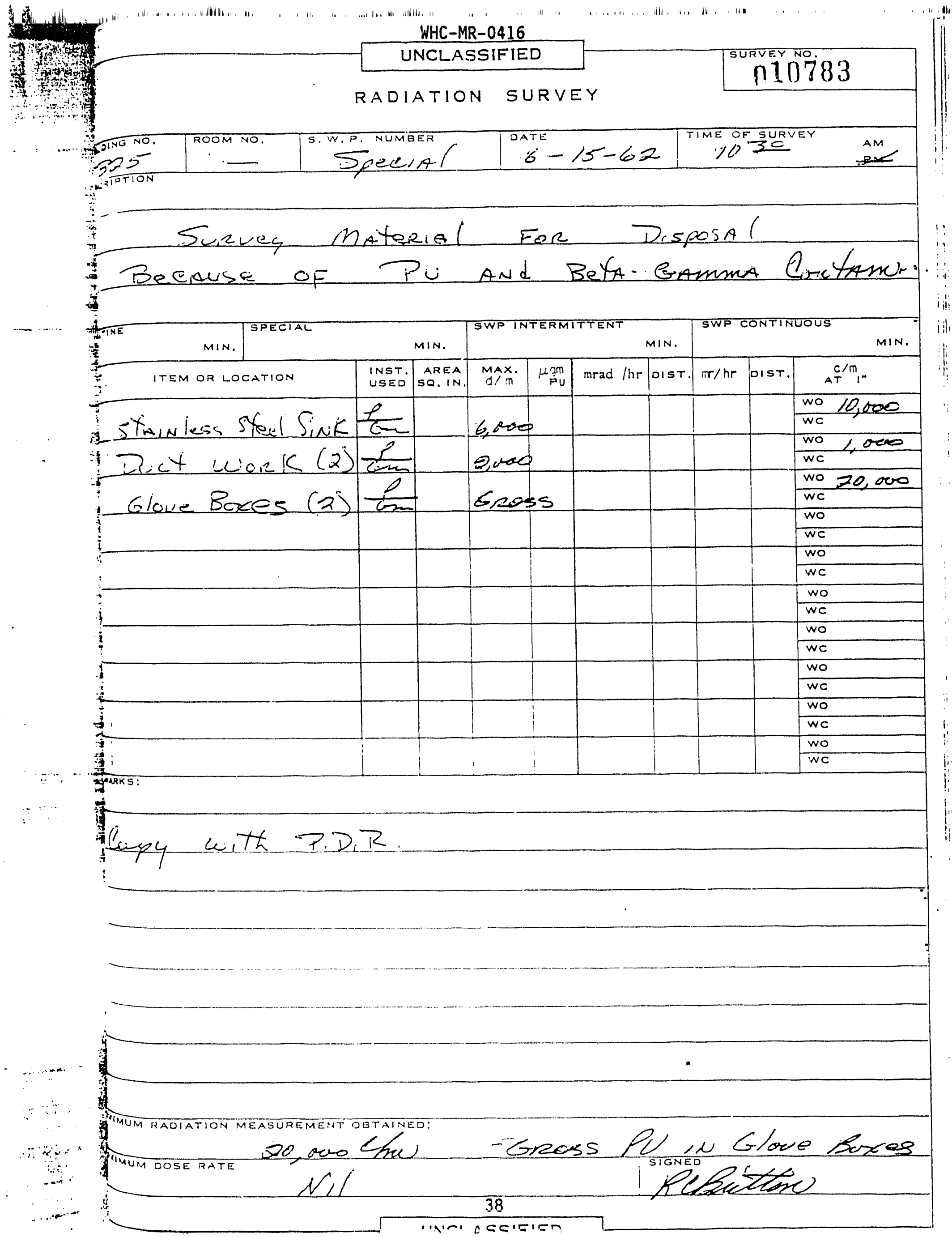




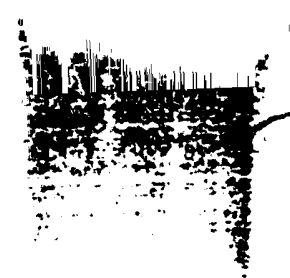

RADIATION SURVEY

\begin{tabular}{|c|c|c|c|c|c|c|c|c|c|c|c|}
\hline \multicolumn{3}{|r|}{$\because \because 2$ is } & & $\begin{array}{c}\text { TATE } \\
0\end{array}$ & TIME OF SURVEY & & & & & & DATE \\
\hline
\end{tabular}

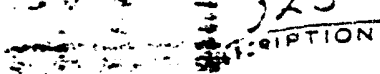

(a)

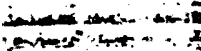

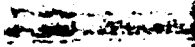

要运

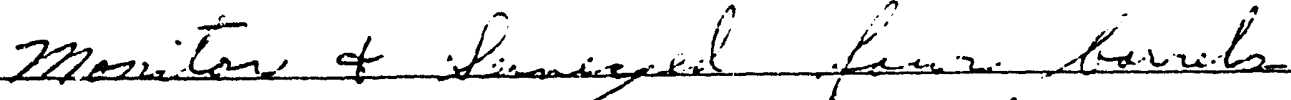

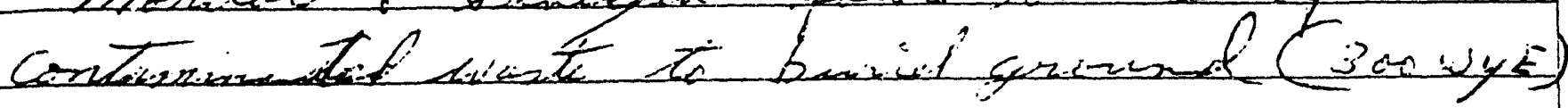

and

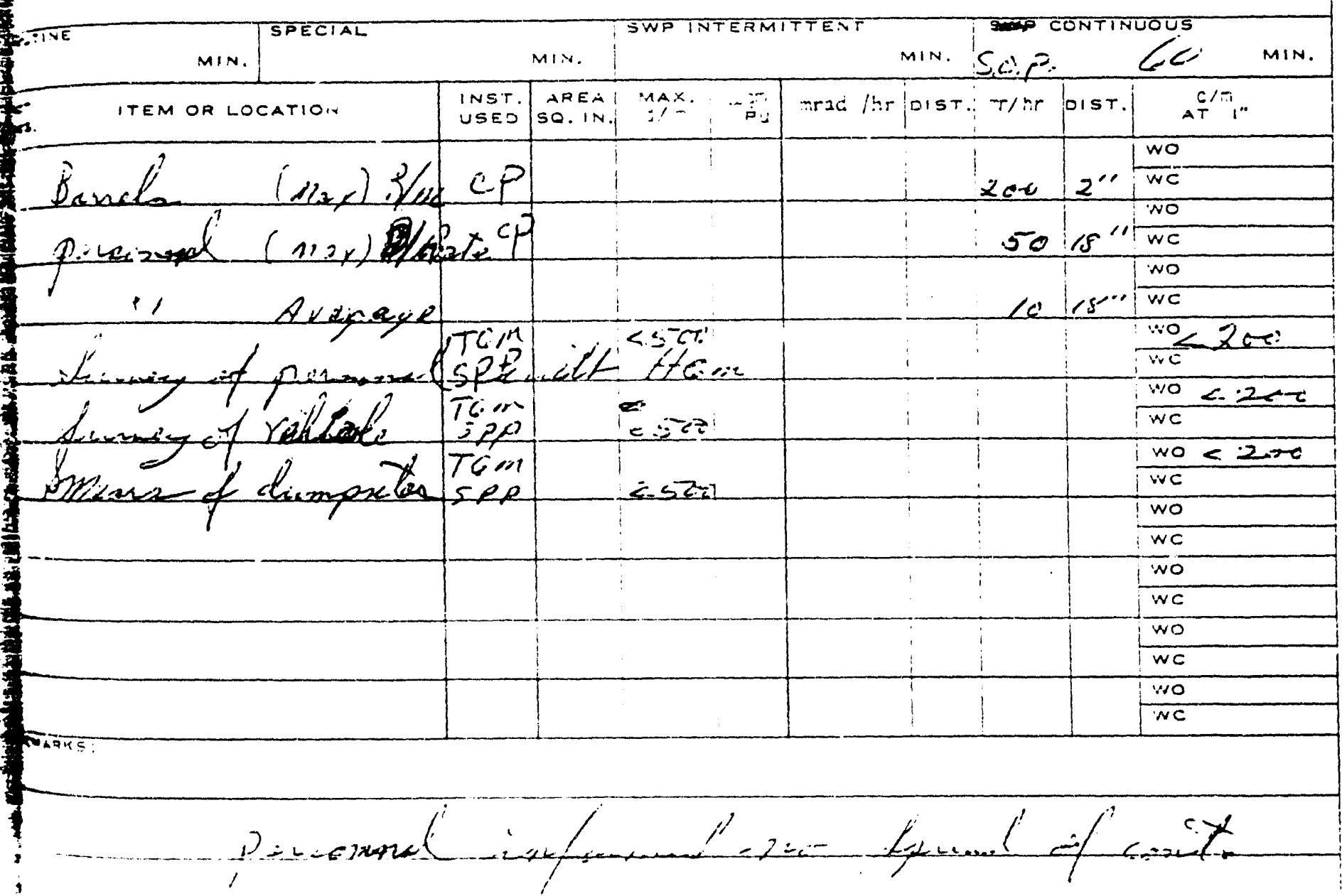

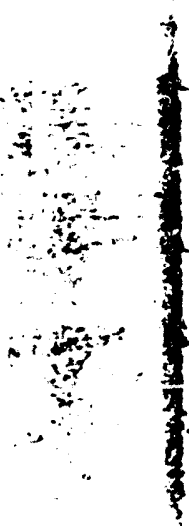

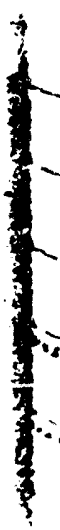

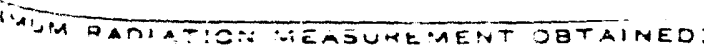

Xce nir/hr 


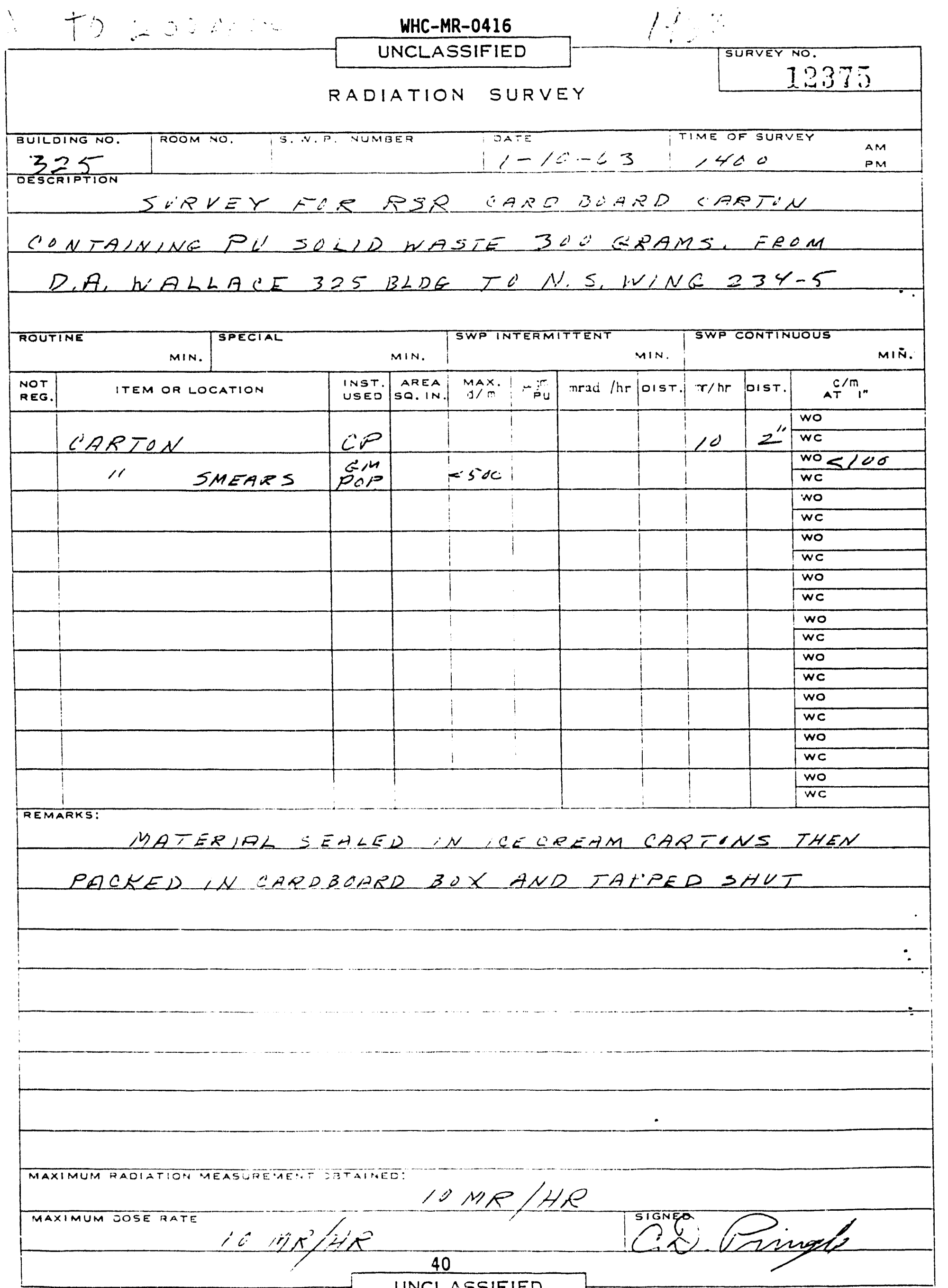

54-3000-190 : -57 ; acer erencane .... 


\section{WHC-MR-0416}

UNCLASSIFIED

RADIATION SURVEY

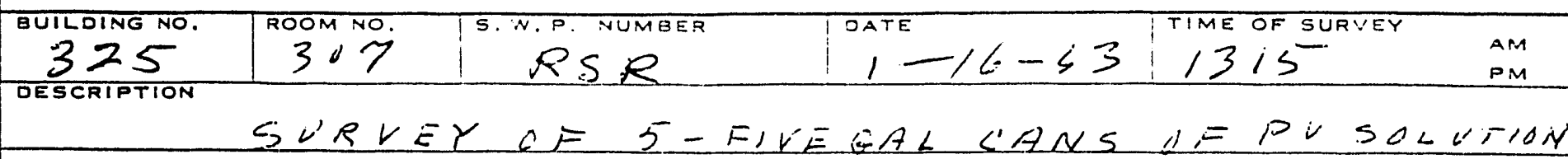
FR.M 325BLDG TOPH. PARKER $2025 B \angle D E$

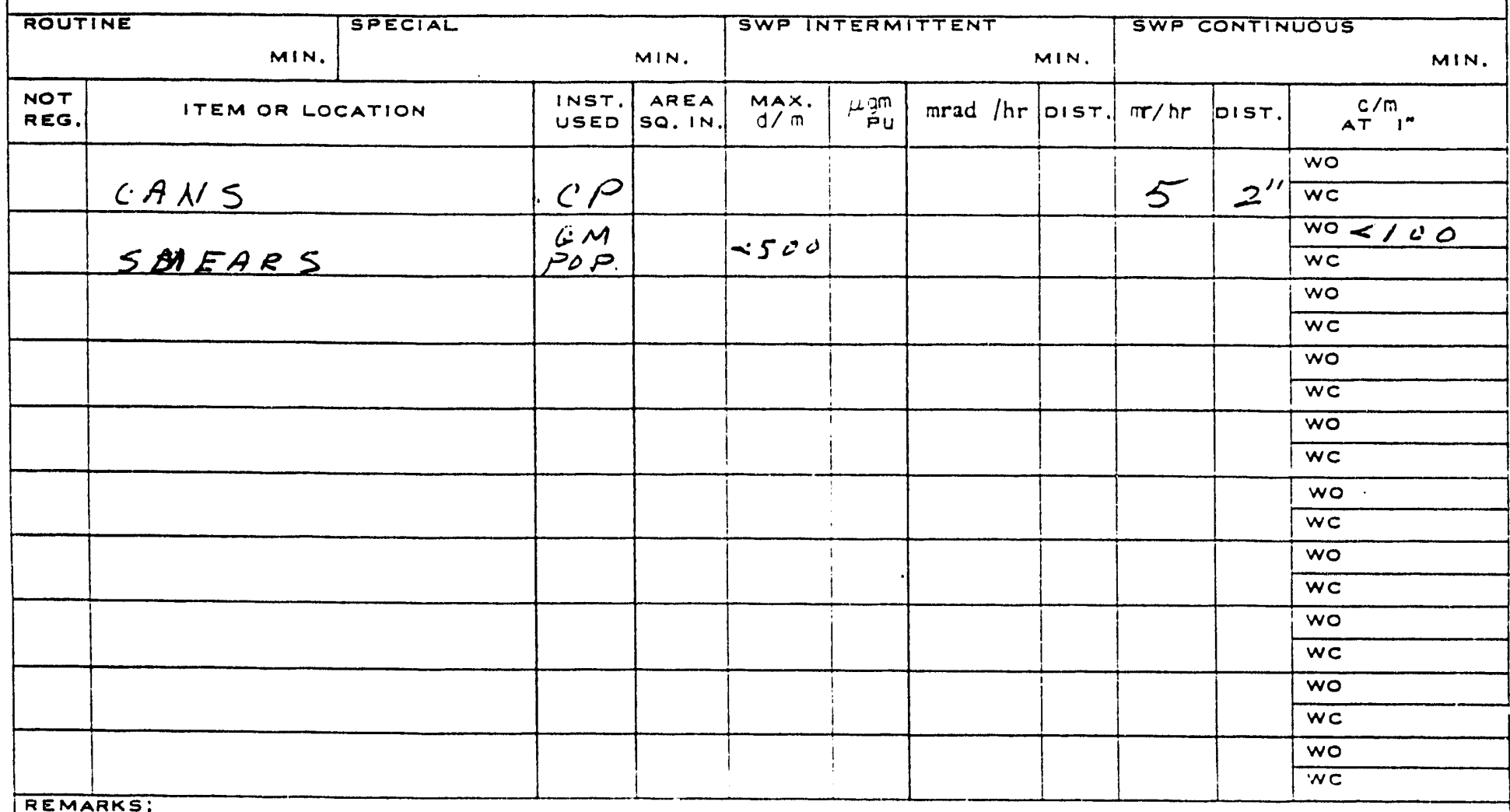

NQ DETECTIBLE CONTAMINATION

MAXIMUM RADIATION MEASUREMENT OETAINED: 


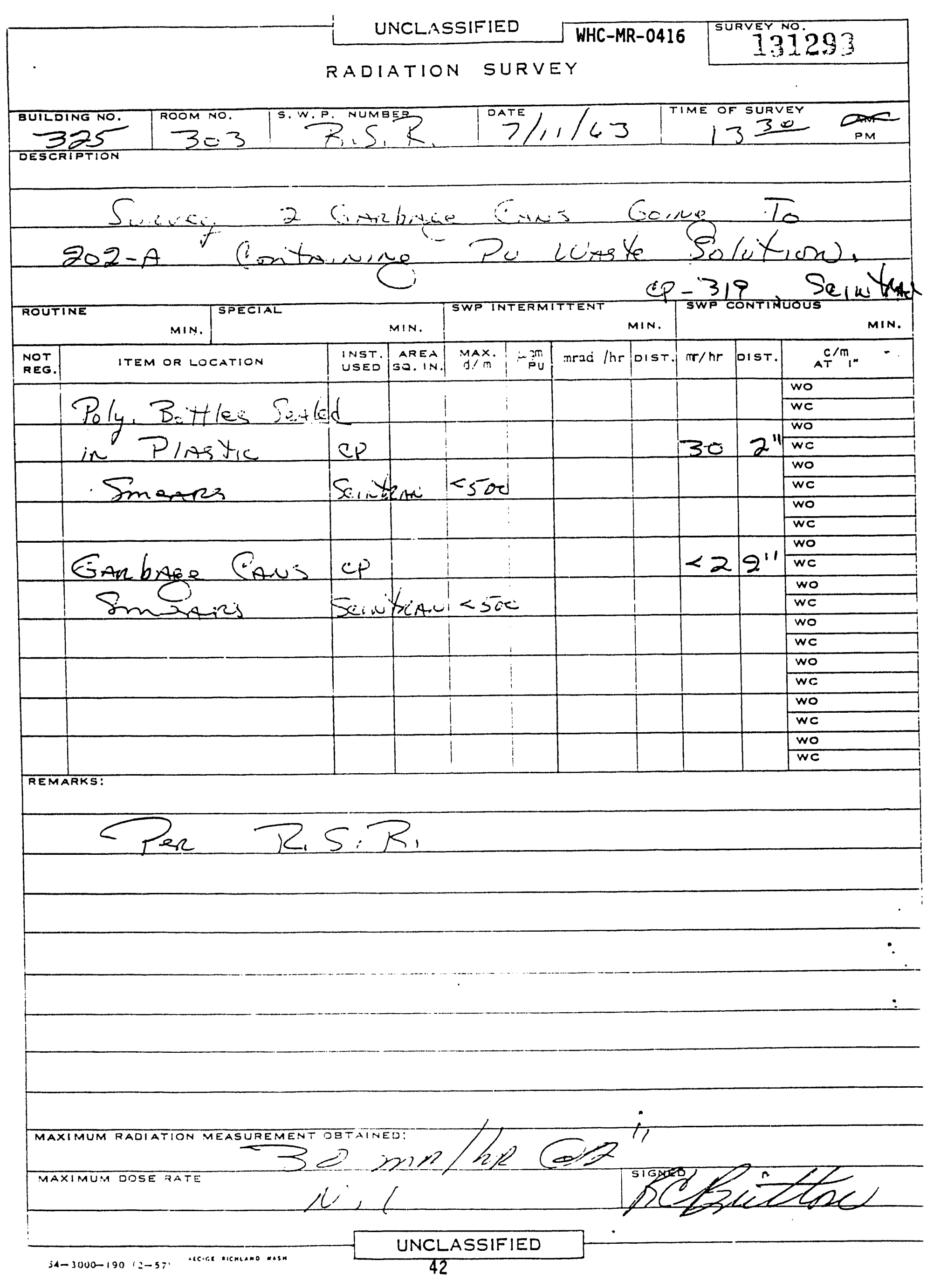


WHC-MR-0416

RADIATION SURVEY

SURVEY NO.

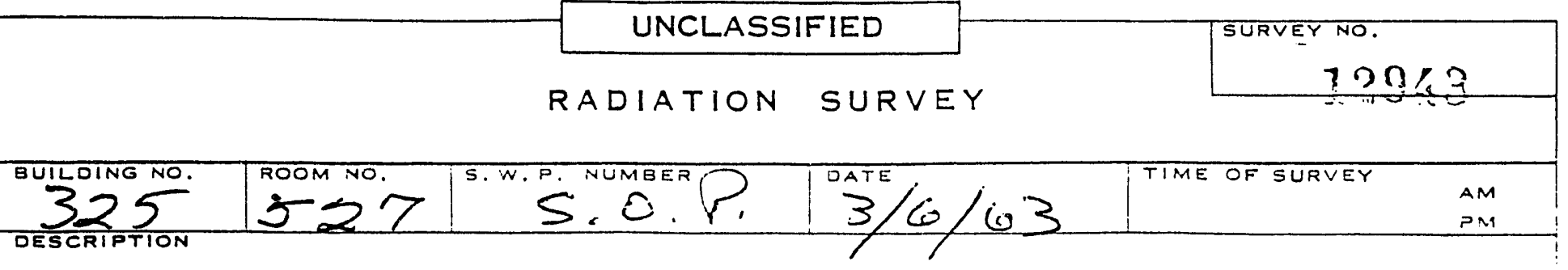

Monitor Placing Cement OUER Pu Bottles From

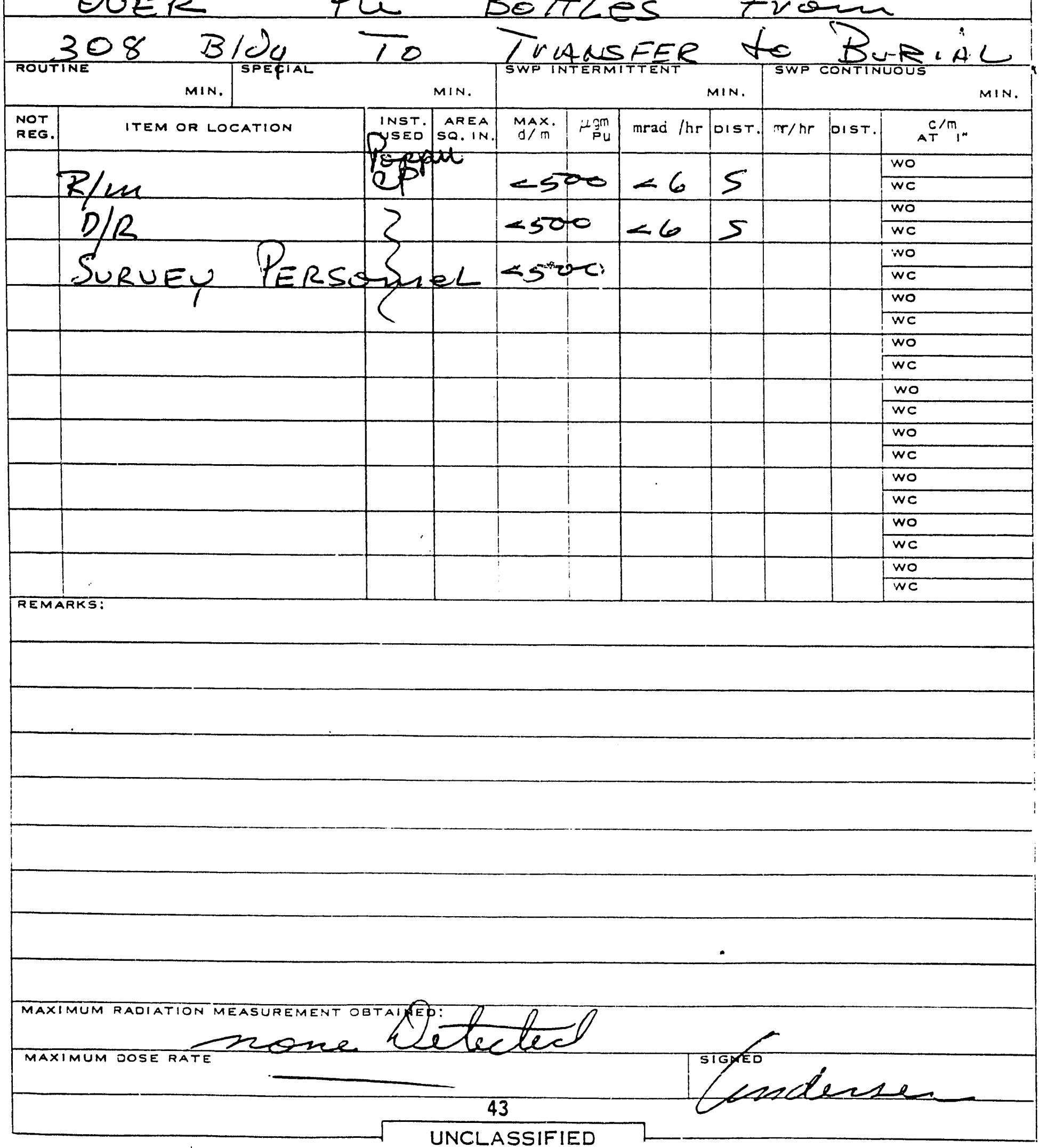




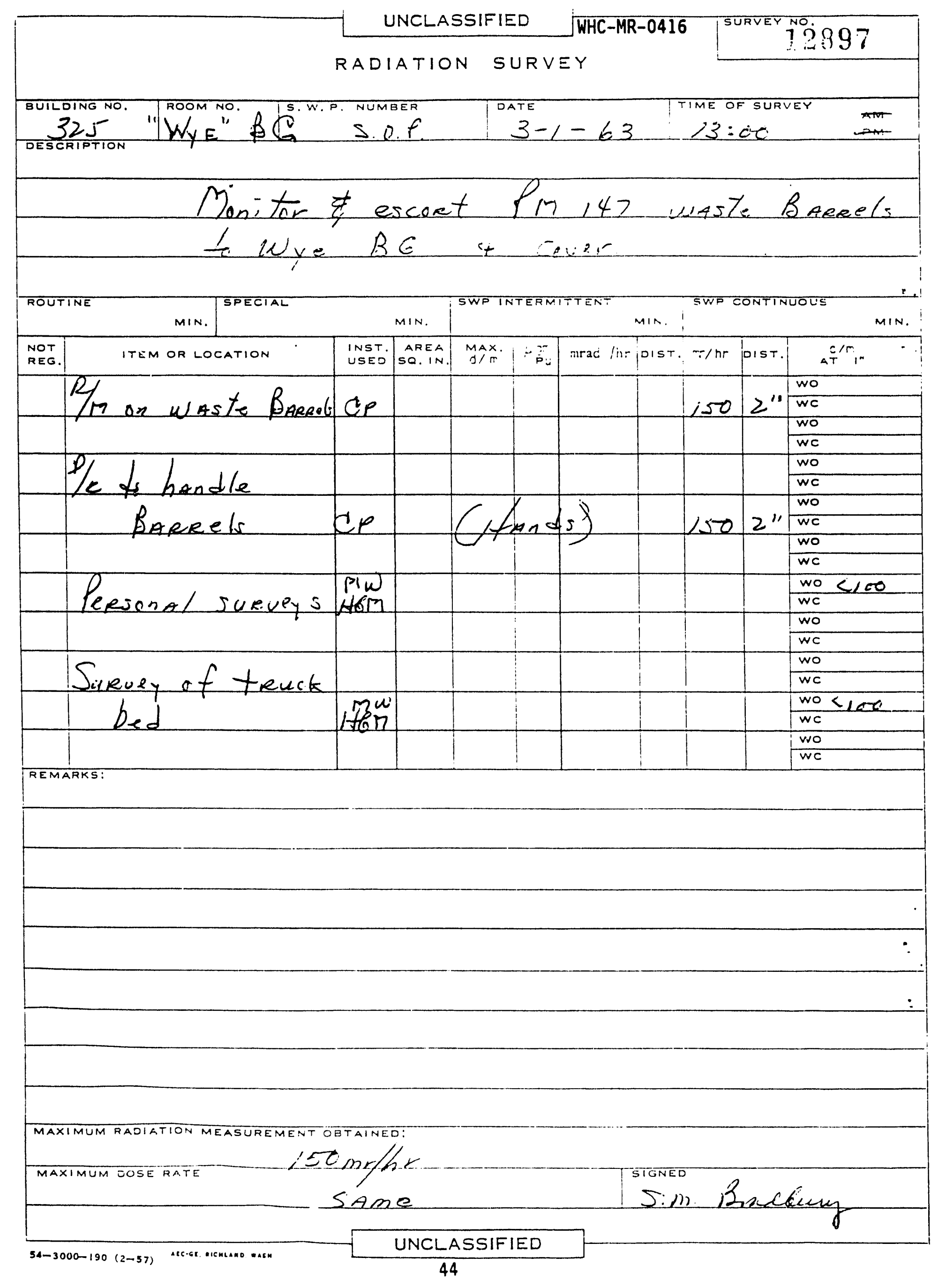




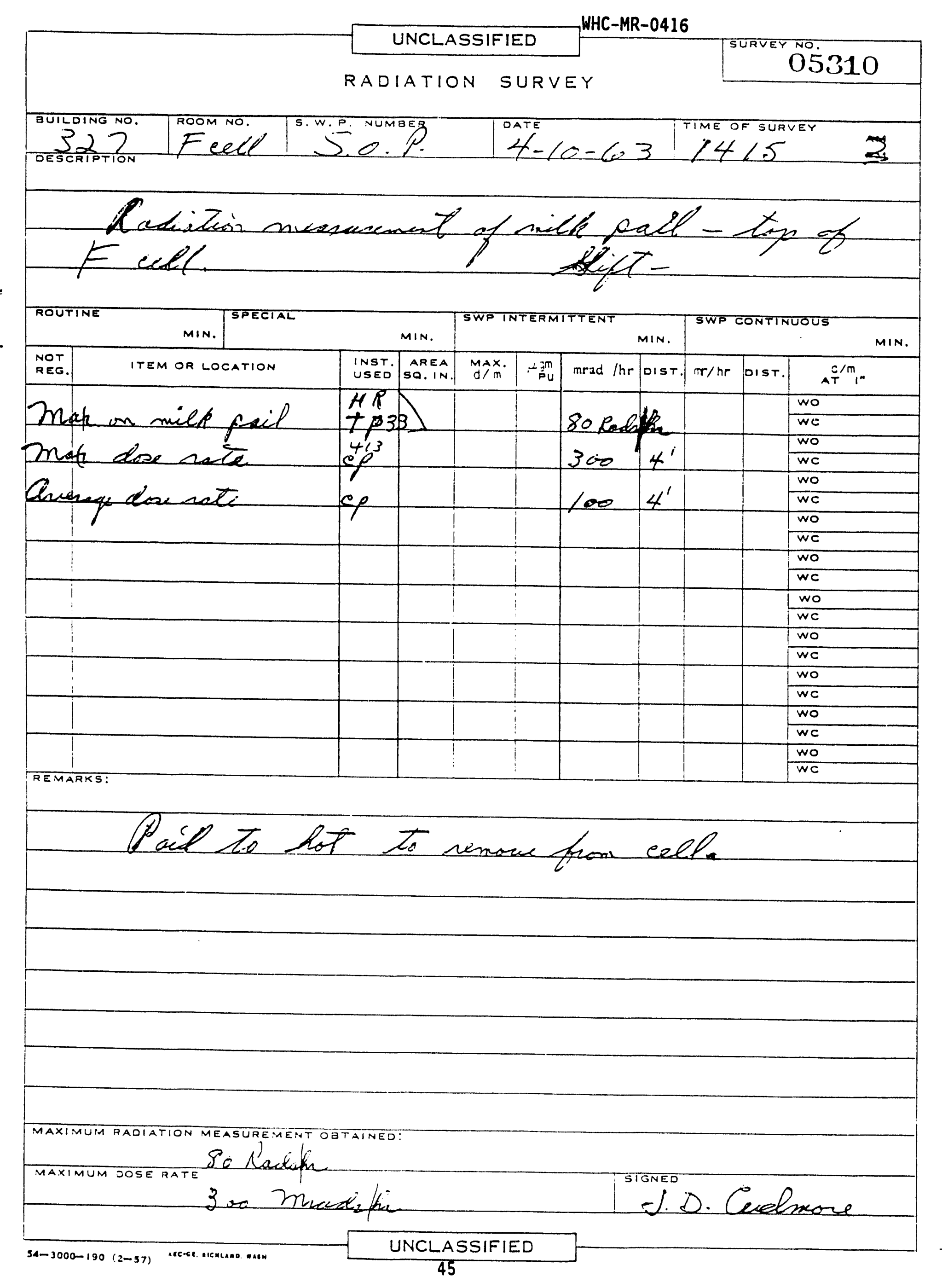




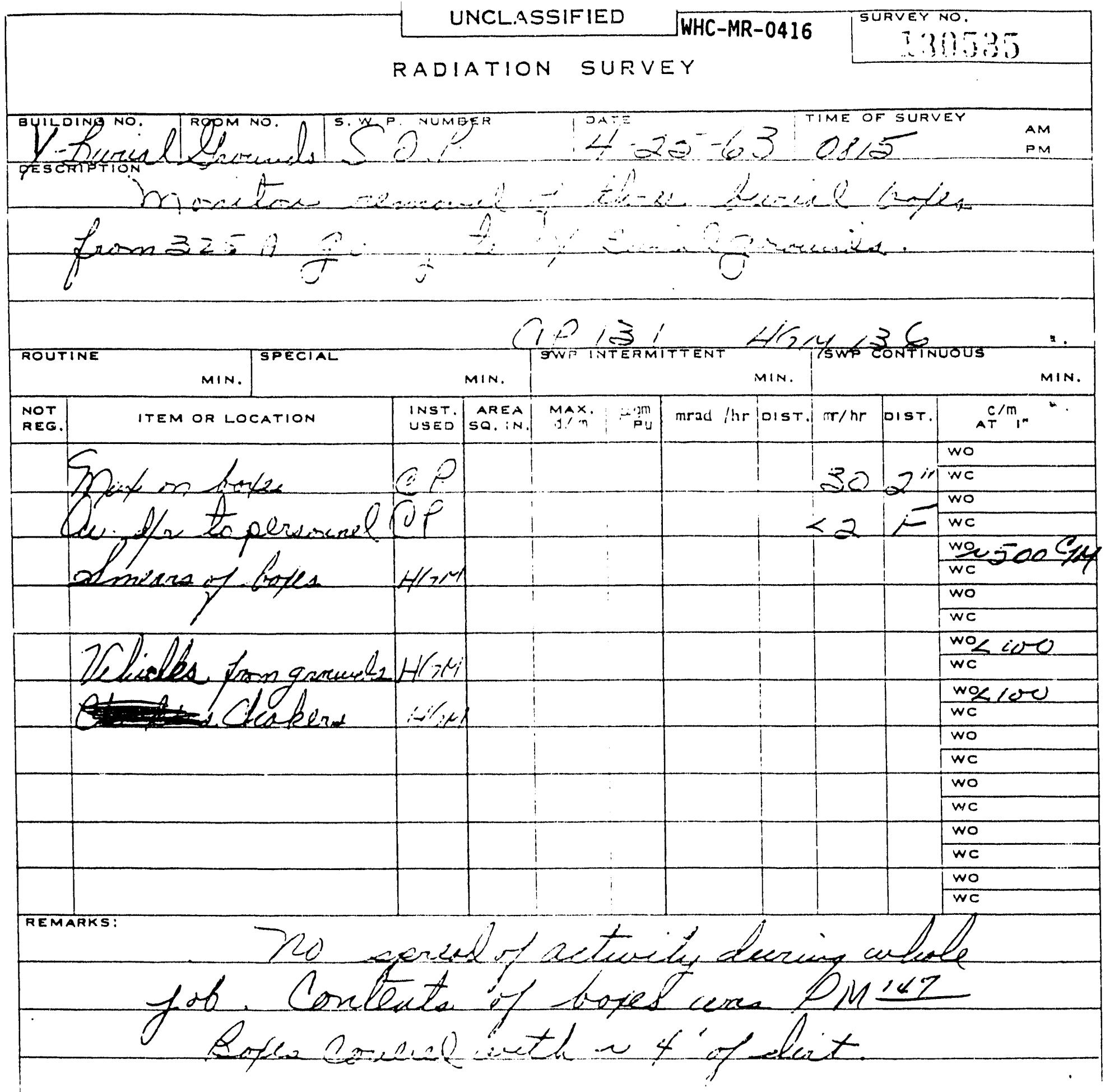

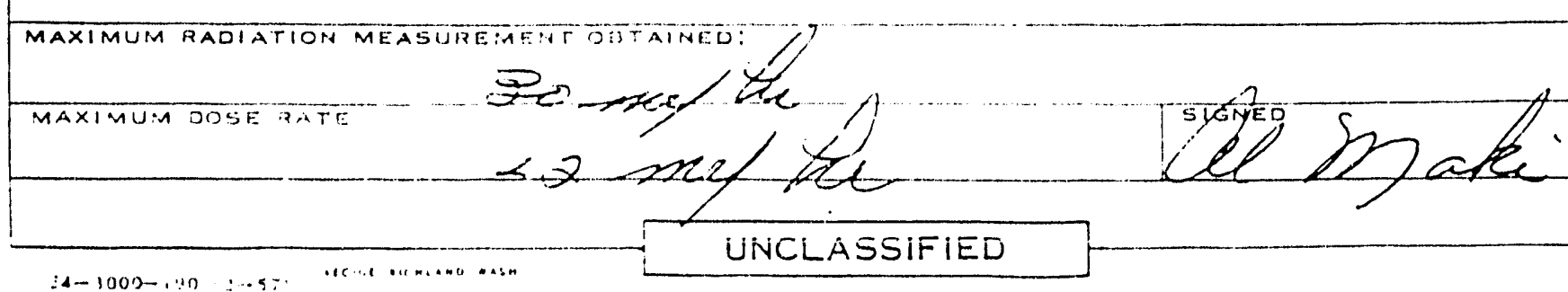




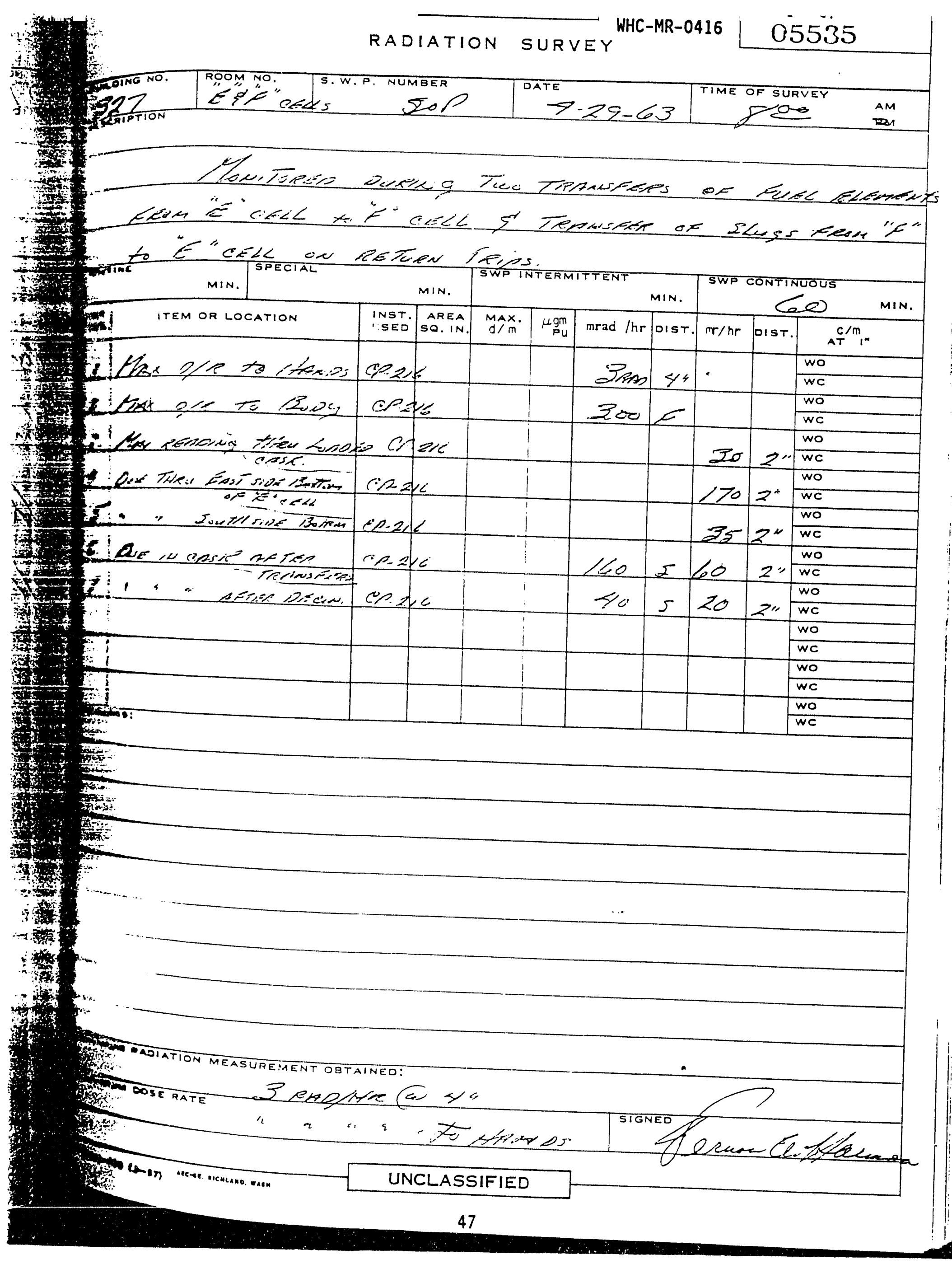




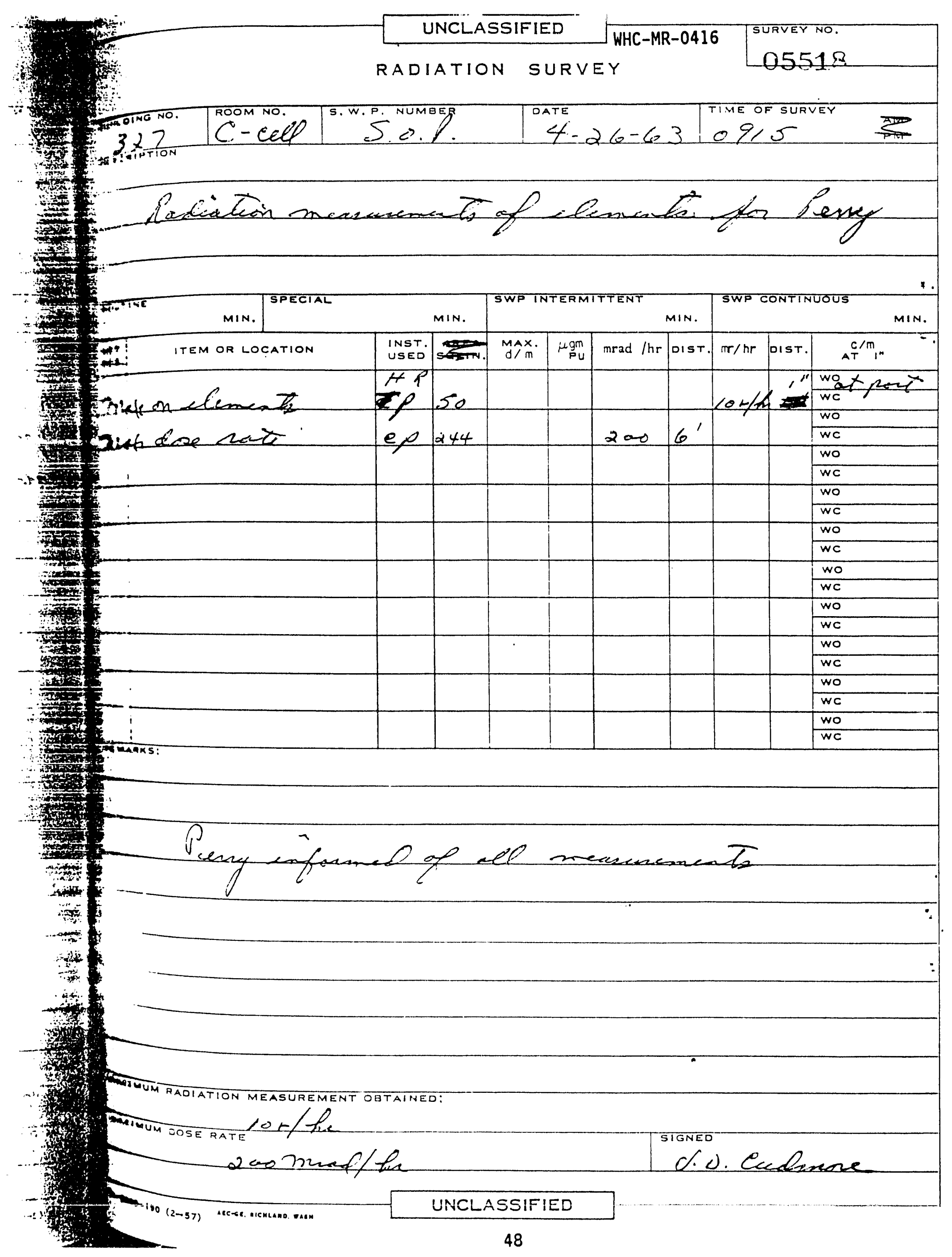




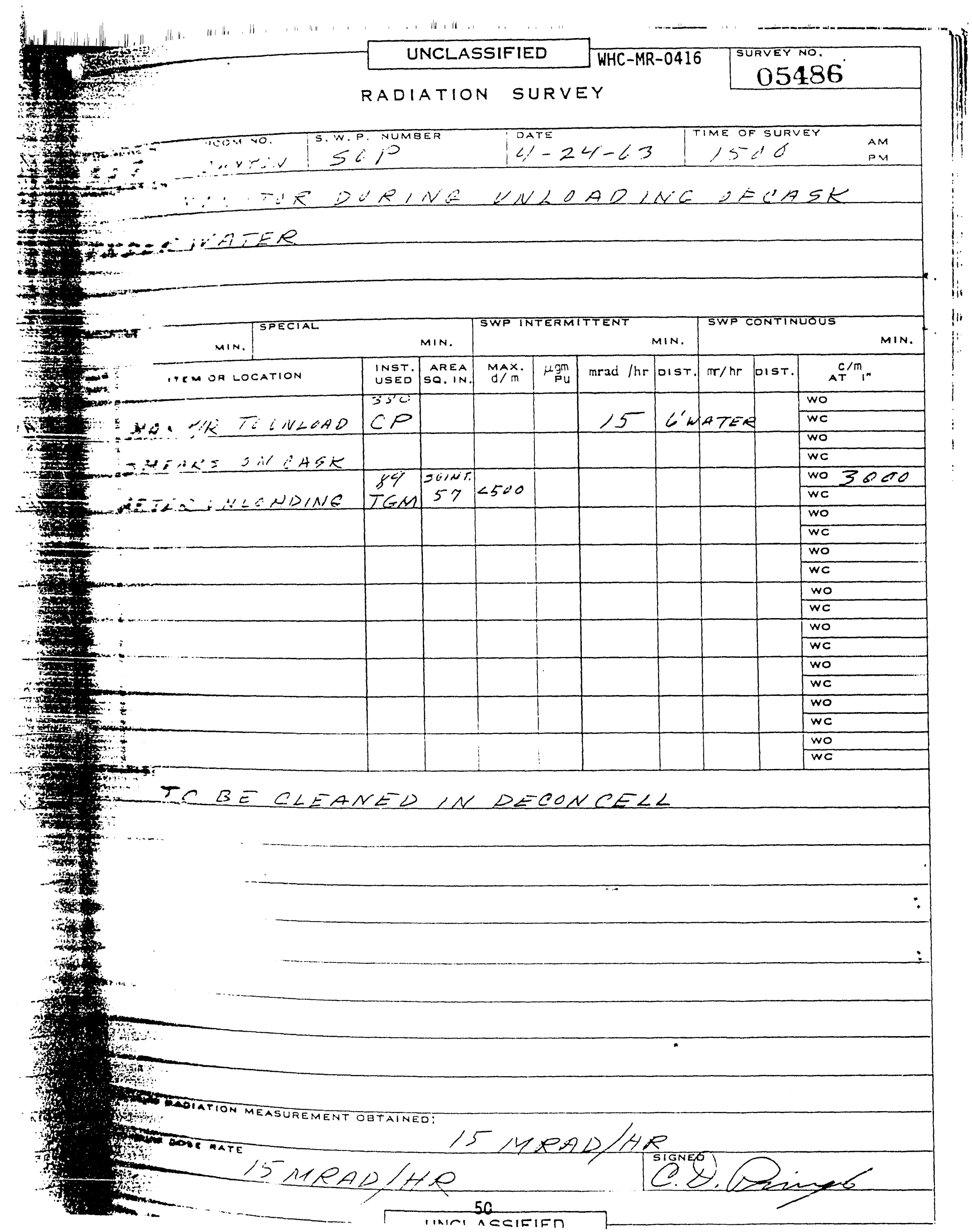




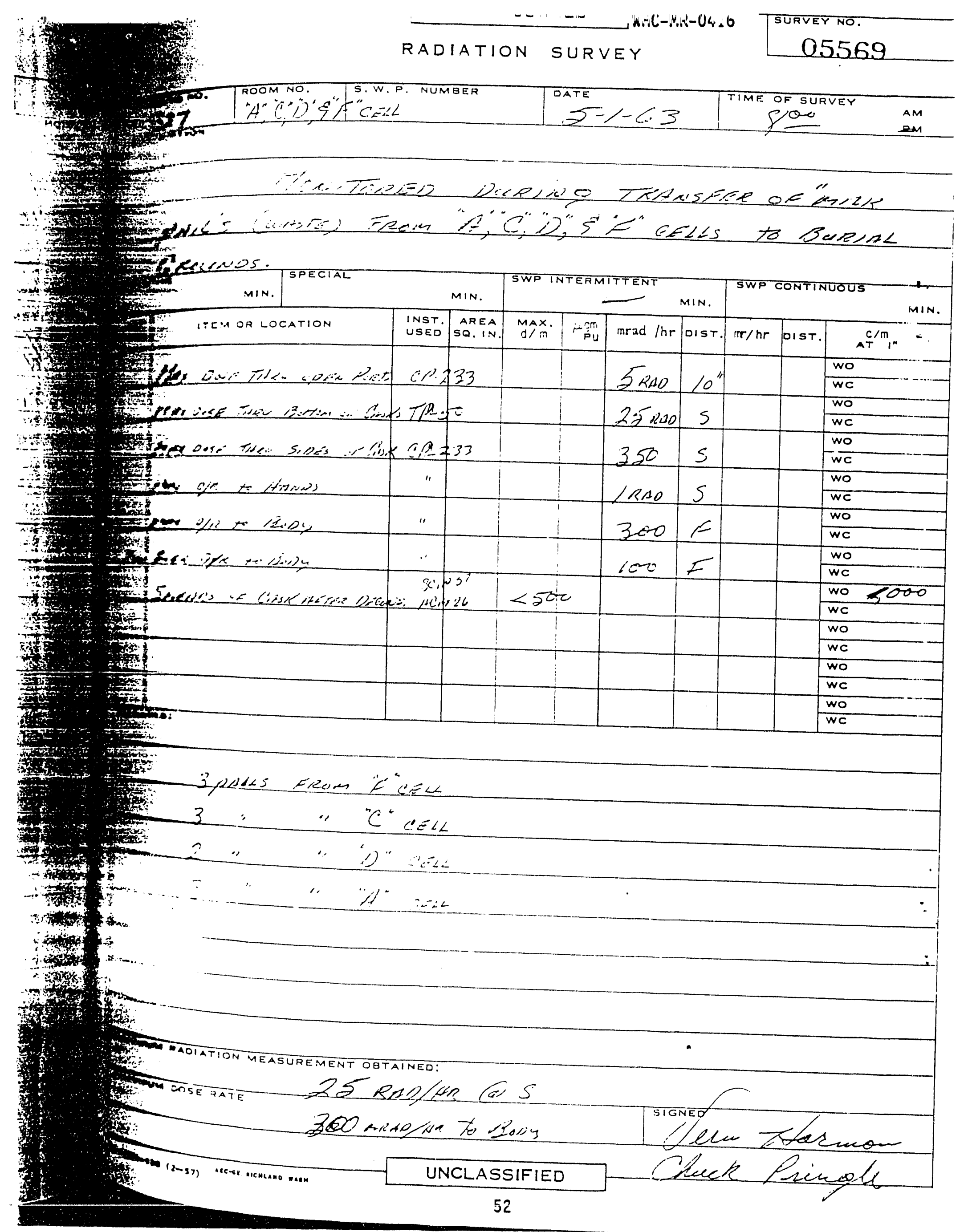


t.

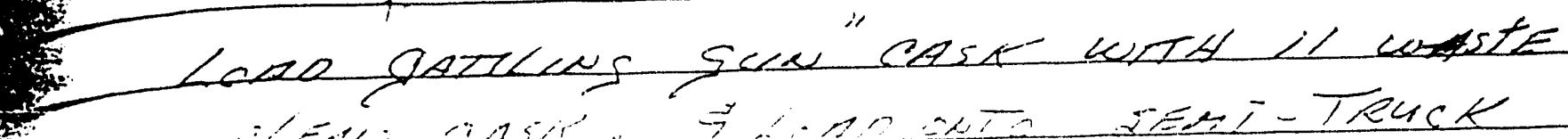

$\rightarrow+4+4$

in

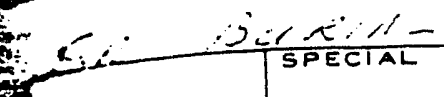

WHC-MR-0416

OR LOCATION

ITEM OR LOCATION

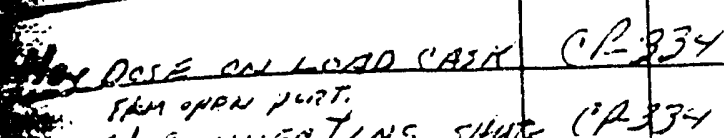

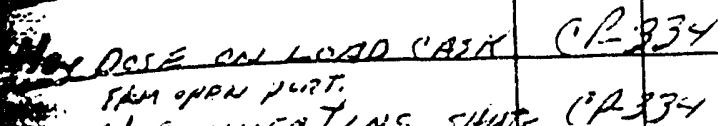

teses.

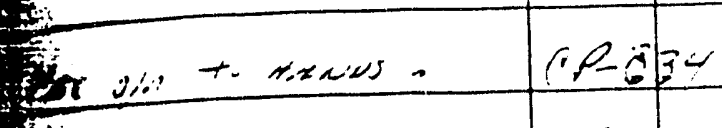

st

$=$

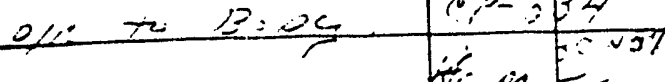

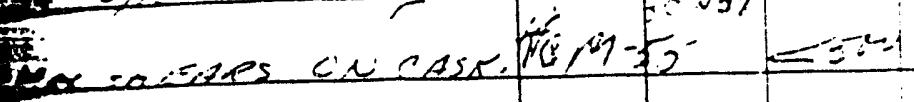

愁

㱐

站

s.

$+8$ 


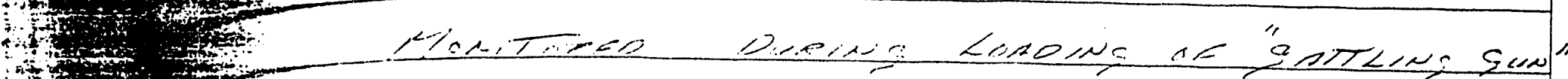

in

1

.

-

y 4

MIN. SPECIAL

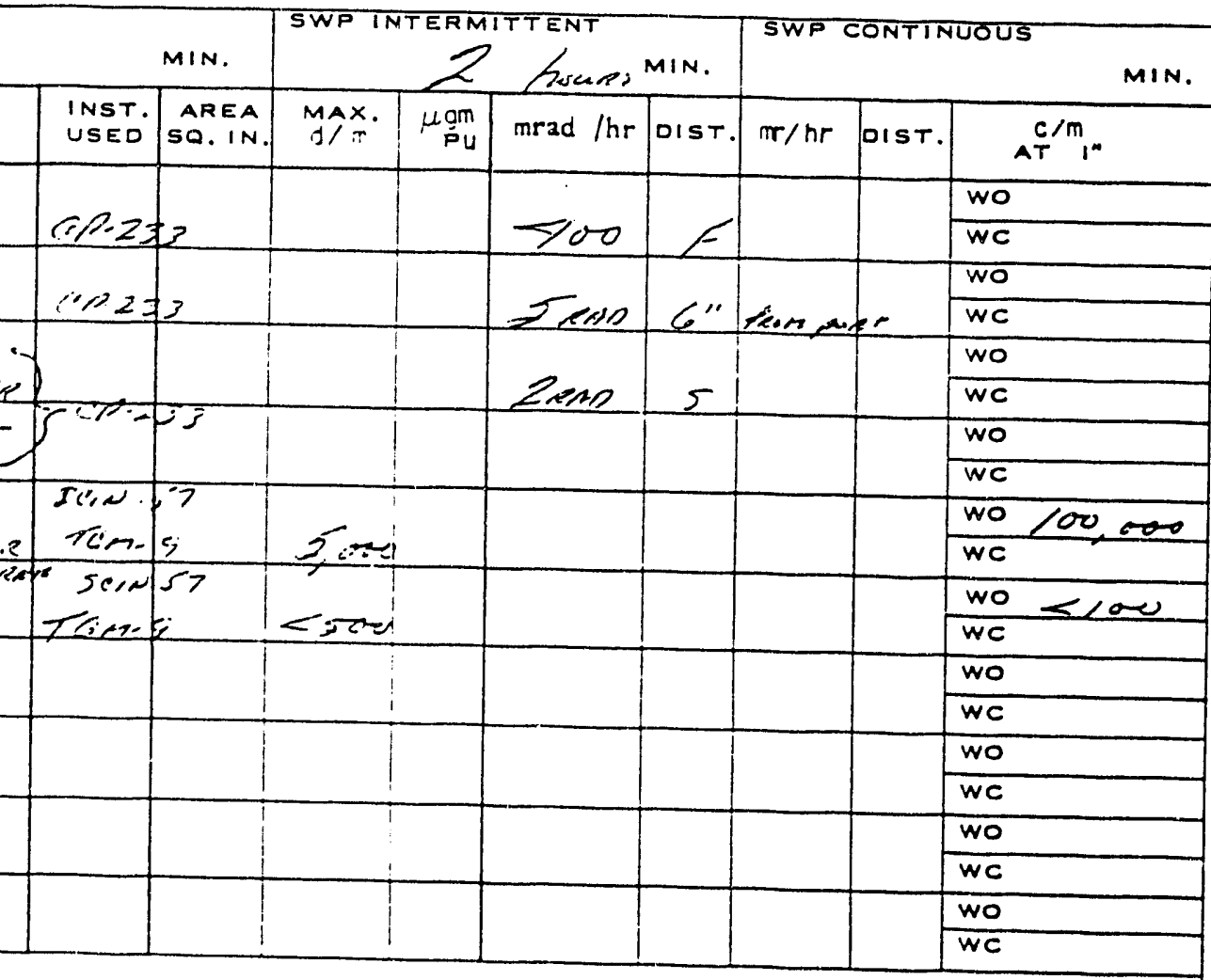

MIISN OR LOCATION

$\operatorname{mon}^{2}$

ats

$\therefore$

int

$402 x_{04}$

ing resinus

int

ive on SHeTIE DETEP

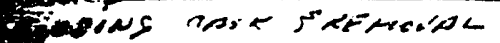

tis

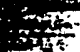

$\frac{17}{4}$

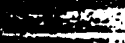

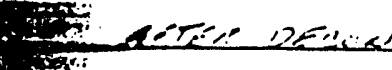

4

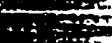

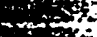

osicis.

$i=$

int

.

5

$\cdots$

$=$

$\therefore$

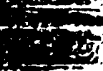

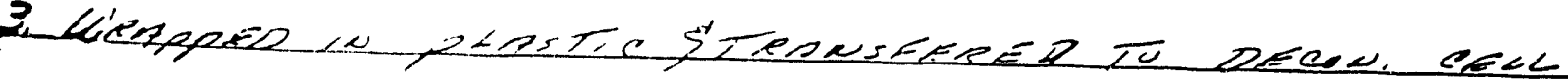
far ortancus.

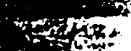

istytar

(t)

sing

Es

sits

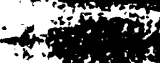

ot

ins

ont

${ }_{10}$

sitis

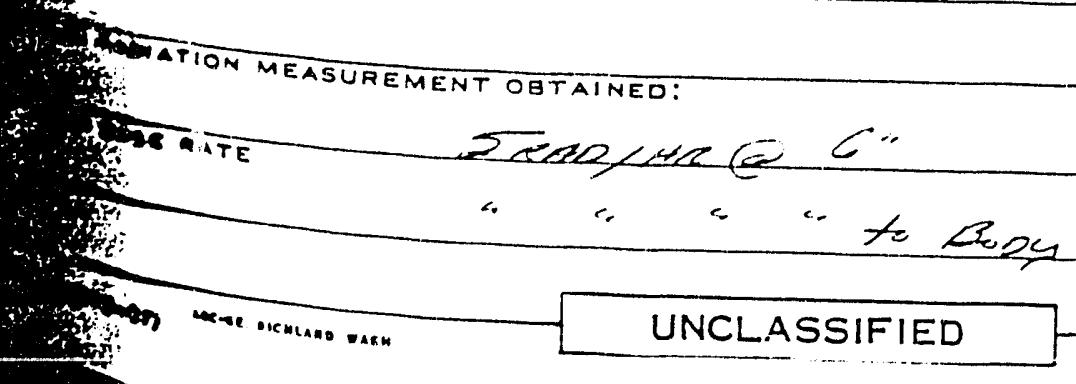

$$
\begin{aligned}
& \text { sane } 4 \text { are C. } \\
& \text { UNCLASSIFIED }
\end{aligned}
$$

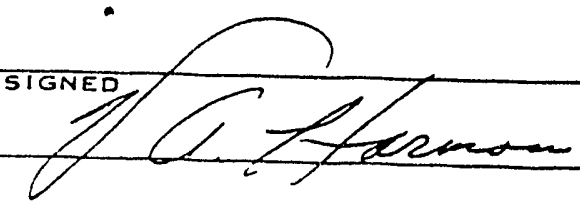



WHC-MR-0416

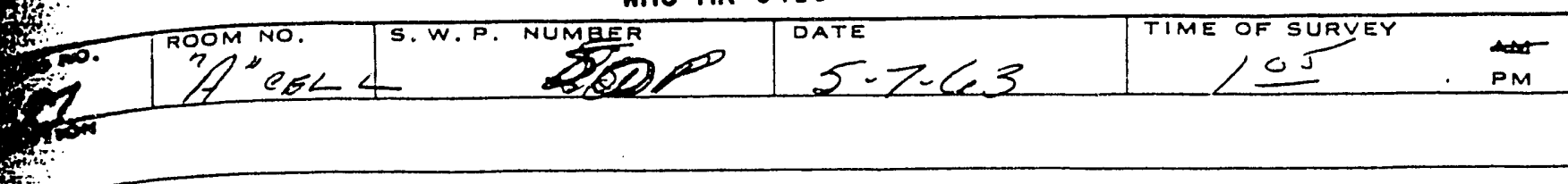

$x+v^{2}+2$

$x_{3}$

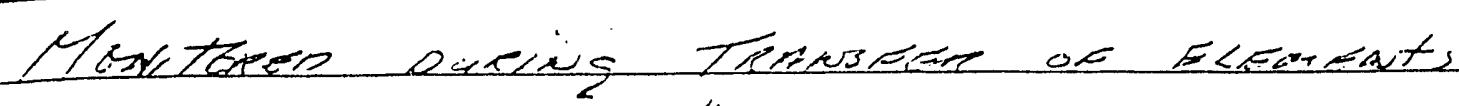

$x \cdot 1 \cdot 0$

(1)

.

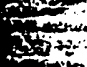

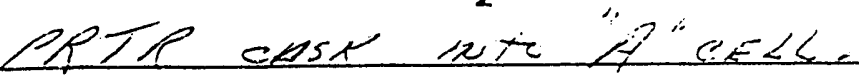

\begin{tabular}{|c|c|c|c|c|c|c|c|c|c|}
\hline MIN. & \multicolumn{2}{|c|}{ SPECIAL } & \multicolumn{4}{|c|}{ SWP INTERMITTENT } & \multicolumn{3}{|c|}{ SWP CONTINUOUS } \\
\hline ITEM OR LOCAation & $\begin{array}{l}\text { INST. } \\
\text { USED }\end{array}$ & AREA & $\underset{d}{\max } \mathbf{m}$ & $\mu \mathrm{Pg}$ & $\operatorname{mrad} / \mathrm{hr}$ & Dist. & \multicolumn{2}{|c|}{$\mathrm{mr} / \mathrm{hr}$ bIST. } & $A^{C / m}{ }^{n}$ \\
\hline \multirow{2}{*}{ 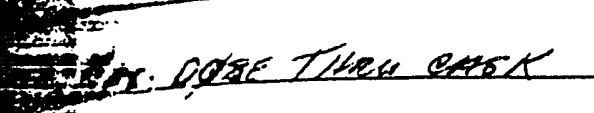 } & \multirow{2}{*}{\multicolumn{2}{|c|}{ CP.Z极 }} & & & \multirow[b]{2}{*}{$z$} & & \multirow[b]{2}{*}{750} & \multirow[b]{2}{*}{$2^{\prime \prime}$} & wo \\
\hline & & & & & & & & & WC \\
\hline \multirow{2}{*}{ at } & \multirow{2}{*}{1} & & & & & & \multirow{2}{*}{ zo } & \multirow{2}{*}{$F$} & $\frac{\text { wo }}{\text { wc }}$ \\
\hline & & & & & & & & & wo \\
\hline \multirow{3}{*}{ 政 } & \multirow{3}{*}{$\prime \prime$} & & & & & & \multirow[t]{3}{*}{ le } & \multirow[t]{3}{*}{$c^{\prime}$} & $w c$ \\
\hline & & & & & & & & & wo \\
\hline & & & & & & & & & WC \\
\hline \multirow{2}{*}{ 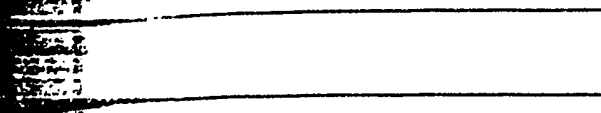 } & & & & & & & & & wo \\
\hline & & & & & & & & & we \\
\hline \multirow{2}{*}{ 政 } & & & & & & & & & wo \\
\hline & & & & & & & & & wc \\
\hline \multirow{4}{*}{ 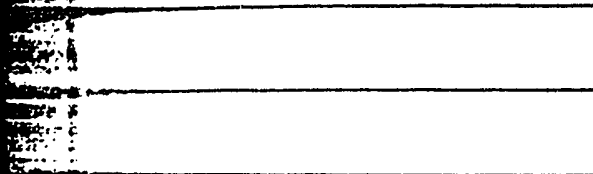 } & & & & & & & & & wo \\
\hline & & & & & & & & & we \\
\hline & & & & & & & & & wo \\
\hline & & & & & & & & & we \\
\hline \multirow{3}{*}{$\frac{1}{2}$} & & & & & & & & & wo \\
\hline & & & & & & & & & wo \\
\hline & & & & & & & & & we \\
\hline
\end{tabular}

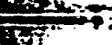

(n)

tran.

.

tos

is:

intios

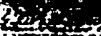

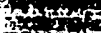

(n)

or

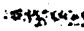

r.

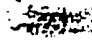

法萑

an:

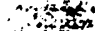

intont

TATATION MEASUREMENT OGTAINED:

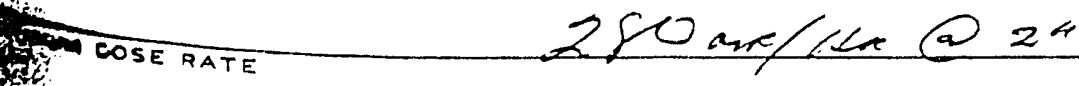

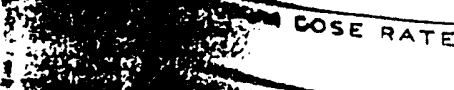

政

$(a-3)$ 


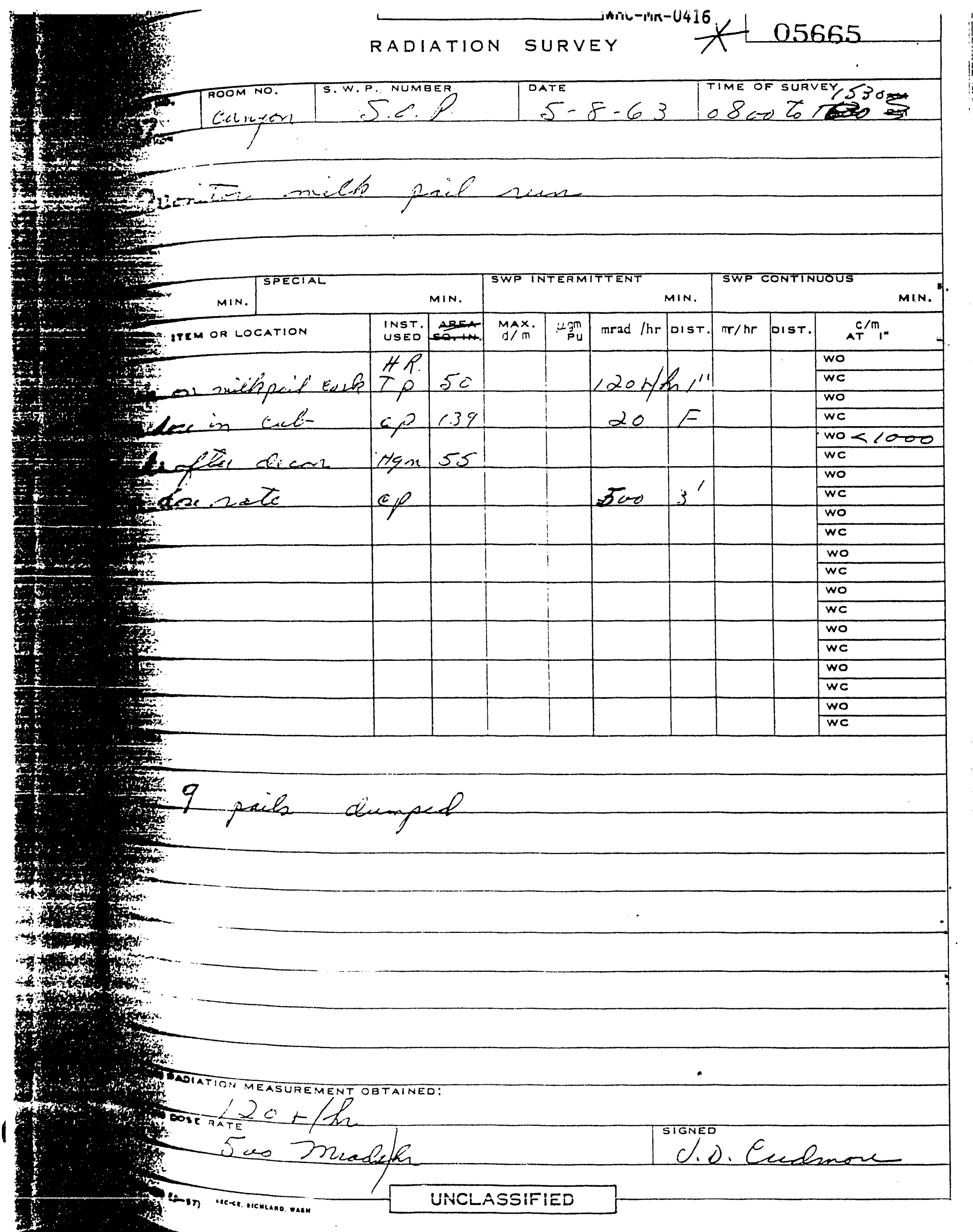




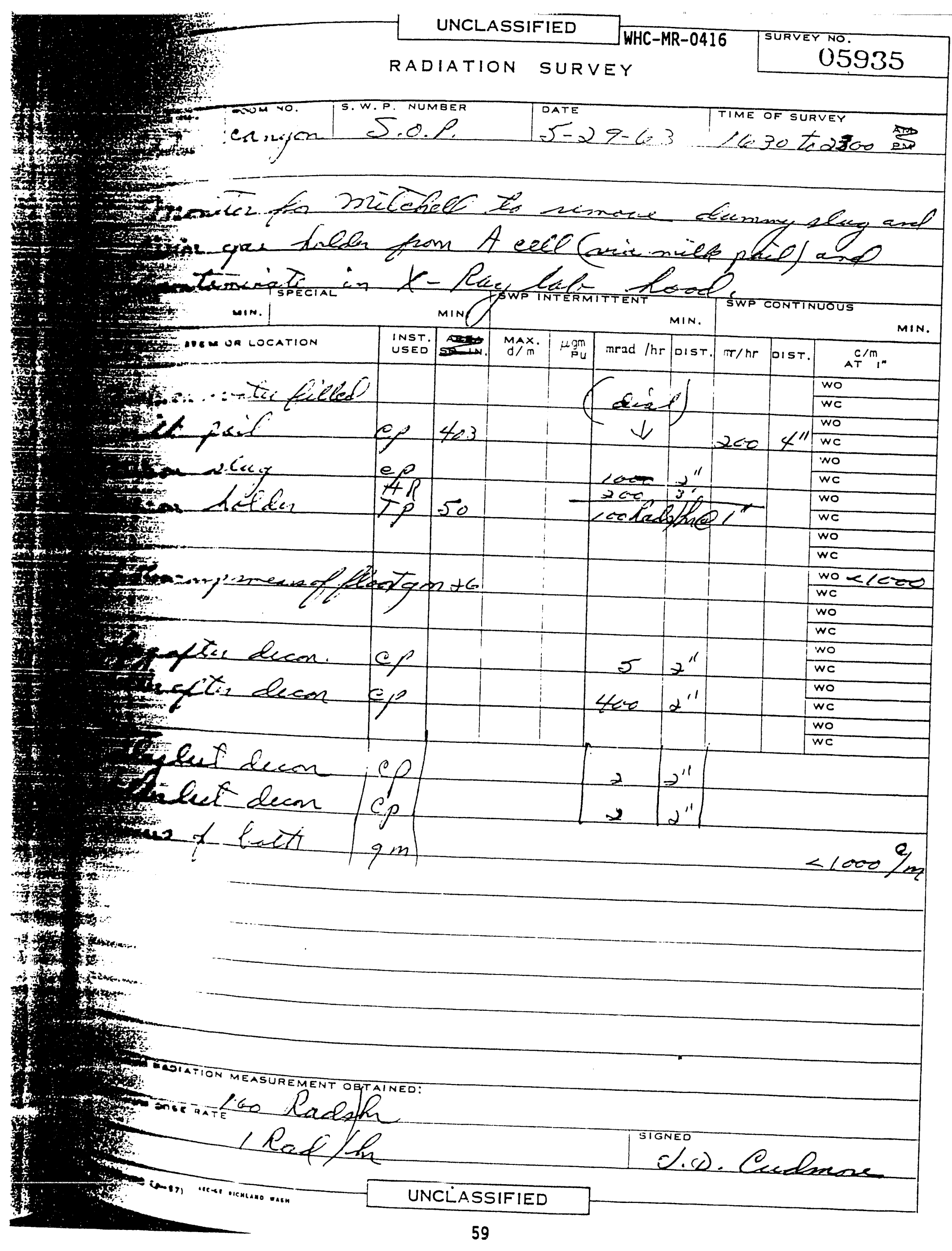




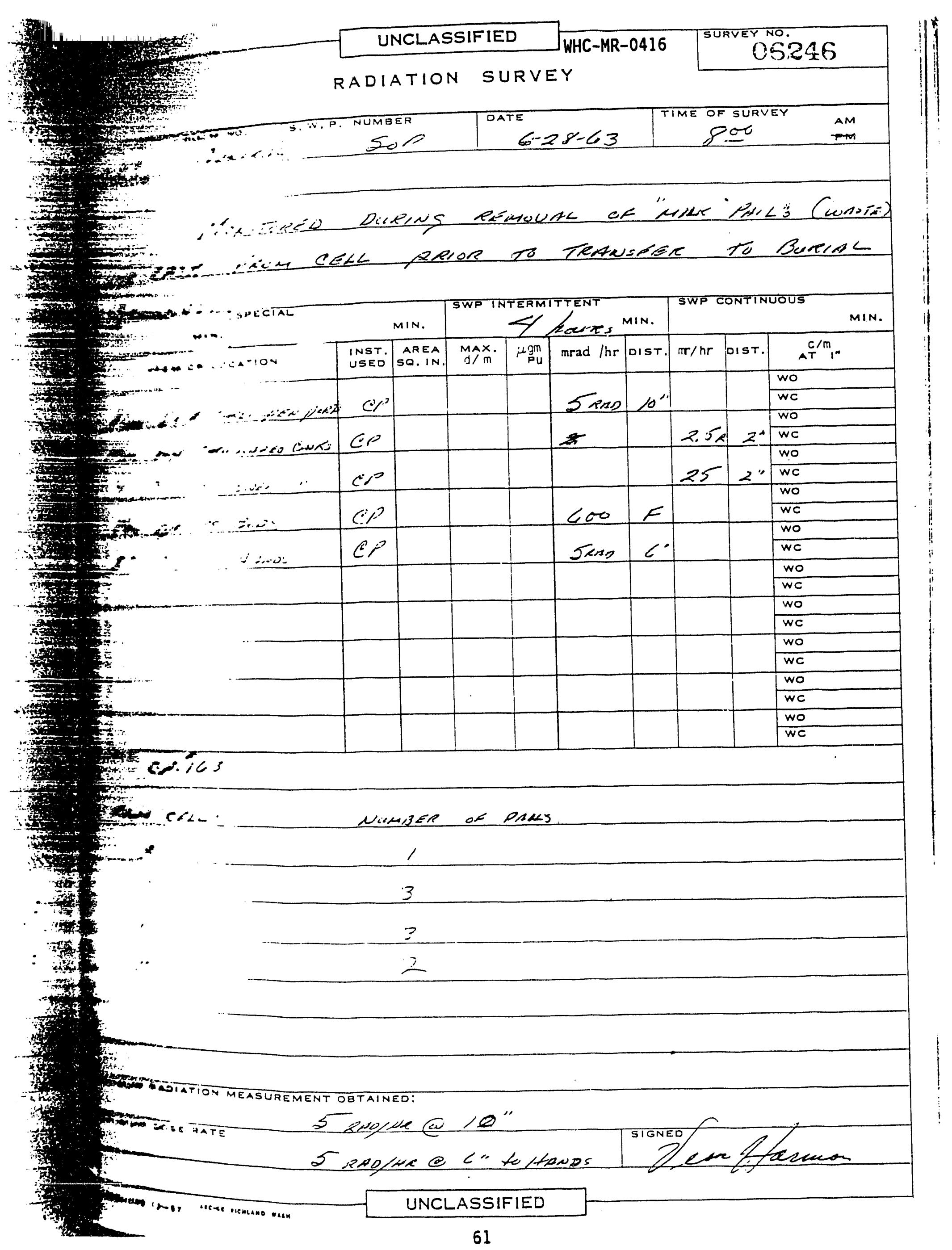




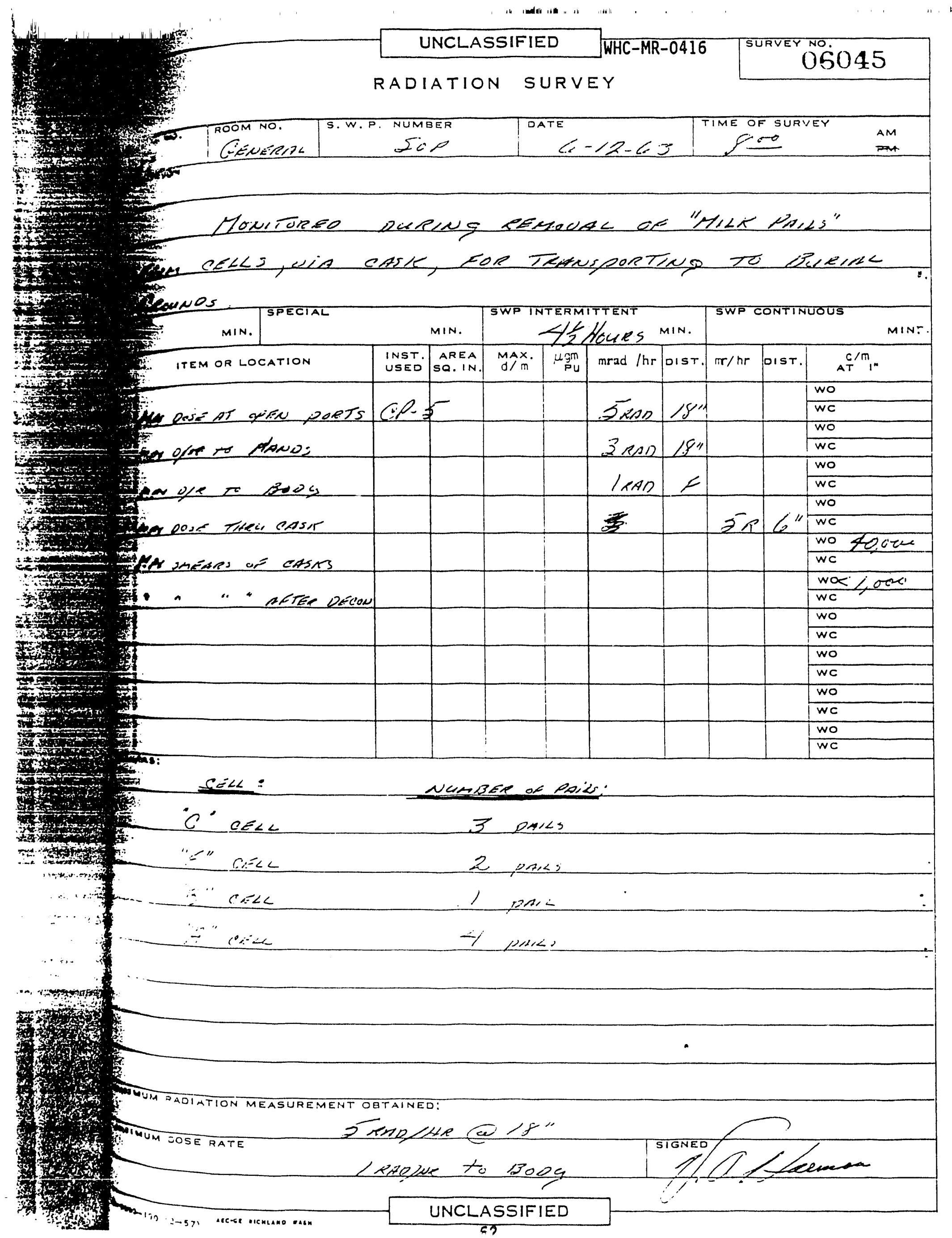




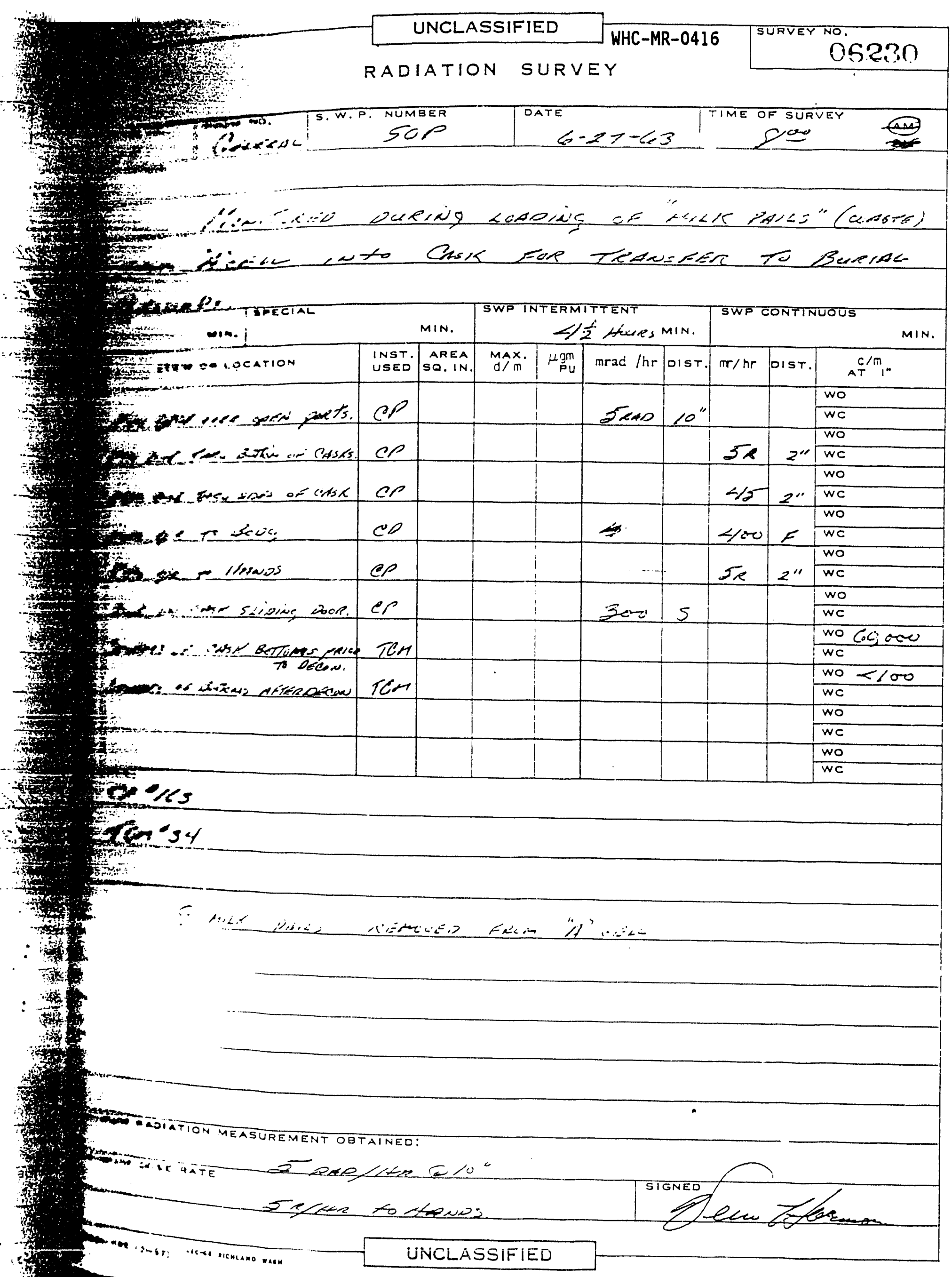




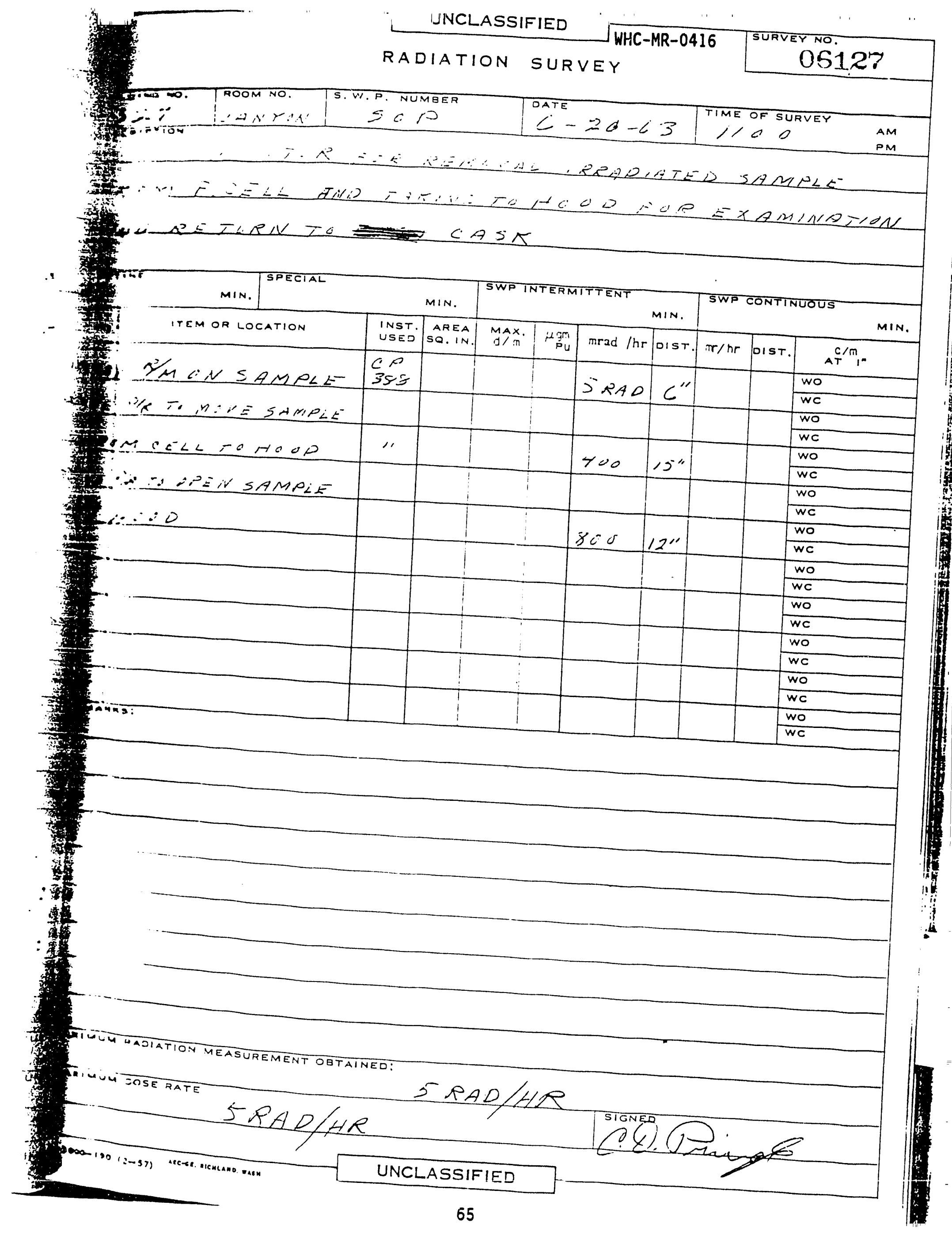




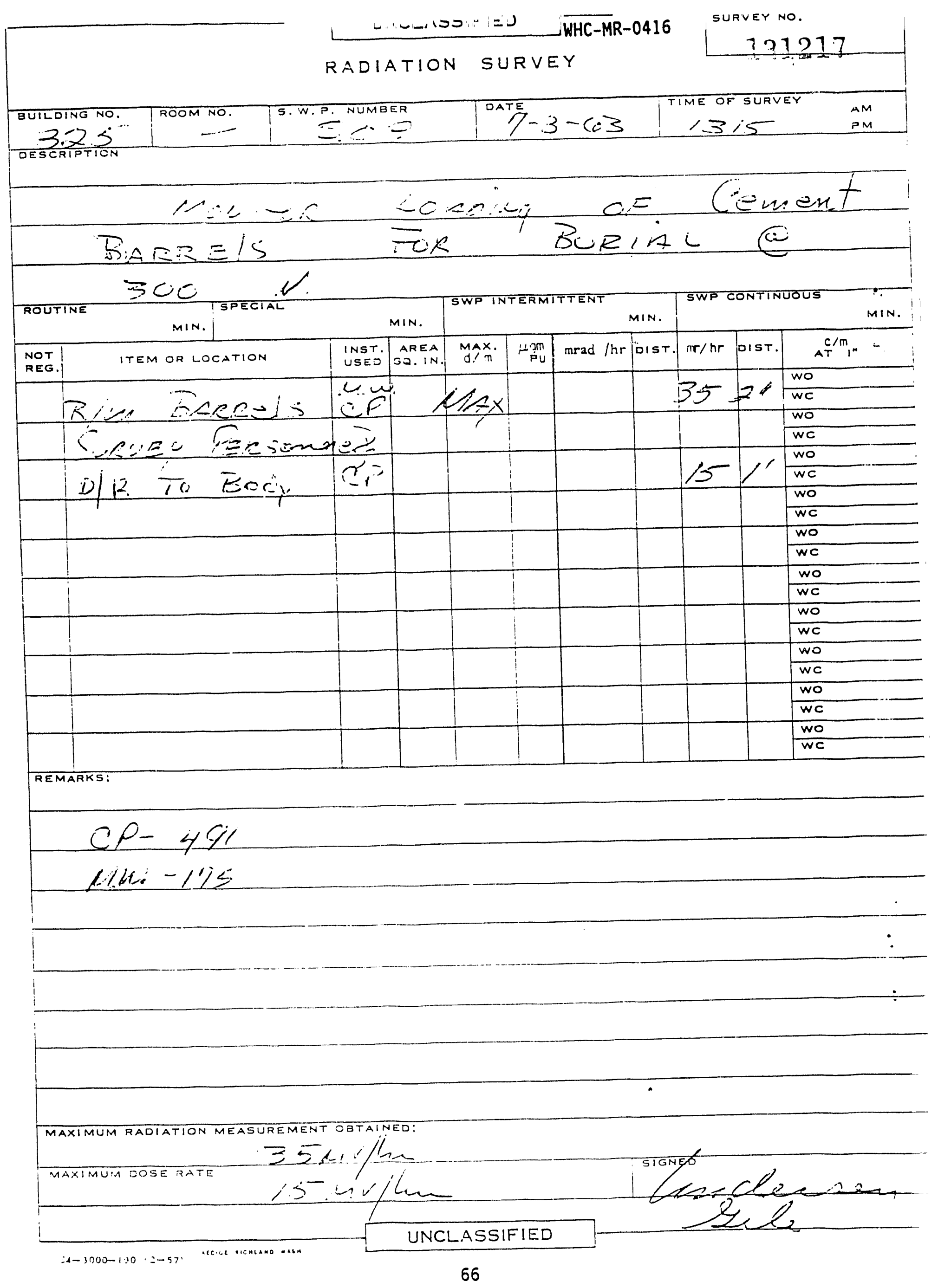




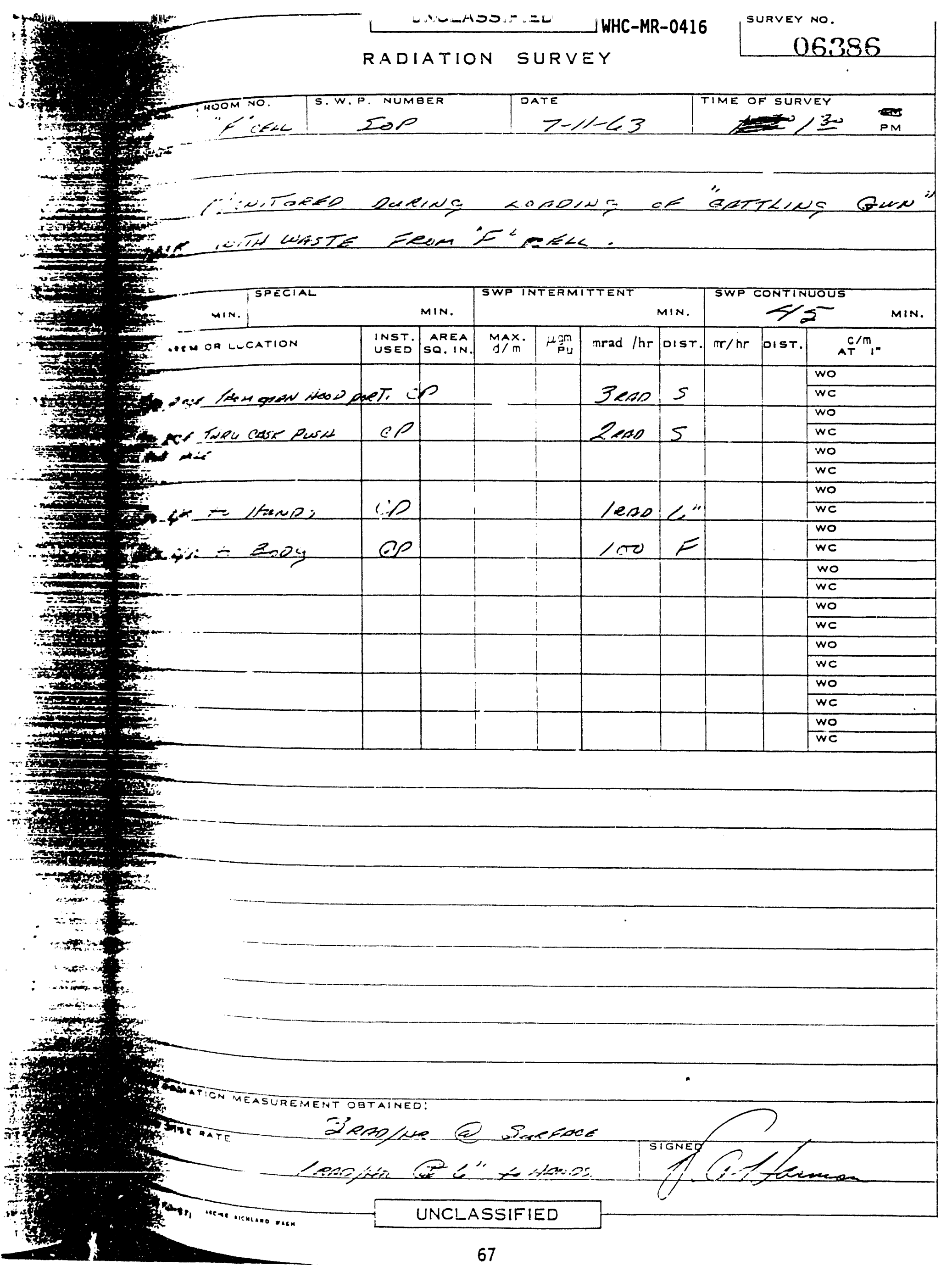


RADIATION SURVEY

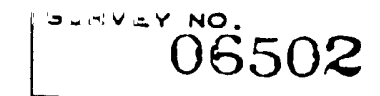

4

स 7

ROOM NO.

GAW YOW

sor

${ }^{\text {DATE }}-19-63$

TIME OF SURVEY

1050

$A M$
$P M$

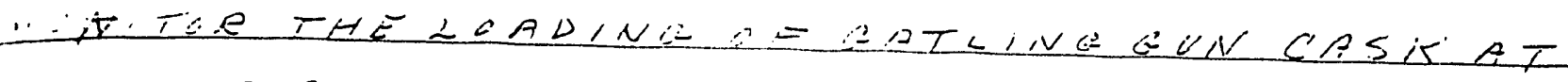

$2+$

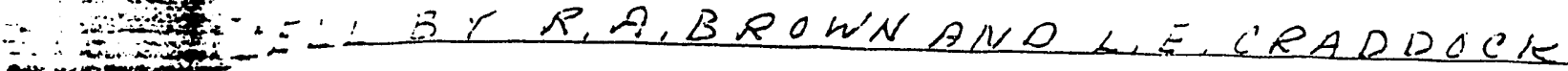

$4=$

$+10$

mon

sindinam

$+1$

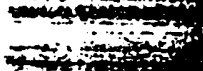

MIN.

\begin{tabular}{|l|l|l|} 
MIN. & SWP INTERMITTENT & SWP CONTINUOUS \\
\hline
\end{tabular}

1.

$\frac{1}{2}=$

: 3

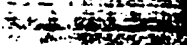

$\therefore$.

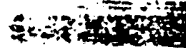

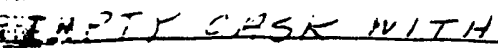

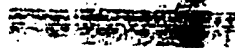

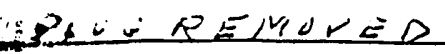

\begin{tabular}{l|l|} 
INST. & AREA \\
USED & SO. IN. \\
\hline
\end{tabular}

A

\begin{tabular}{|l|l|}
$\operatorname{mrad} / \mathrm{hr}$ & $\mathrm{D}$ \\
\hline $35 \mathrm{C}$ &
\end{tabular}

383

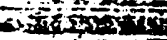

$\therefore=$

rats

4 is itet 20

$\rightarrow 10$

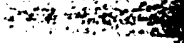

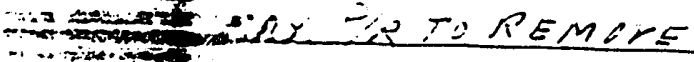

$\because \cdot 7$.

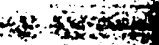

端

27

sitis

in weitat

int

ityon

.

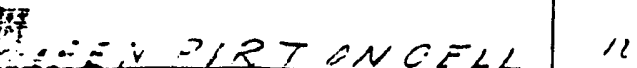

$\therefore 1 / P T Q<O A D$

$a^{2}=5$

WPEDE DIPE EROM PURT

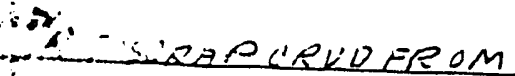

$\therefore=5 L 10$ N B BLOCK

$\sum_{i=0}$

if: : caepr GUIOE

$P P D=$ TO DECON CEL

WOX PISEN ENIOE PLPE

PYKED D

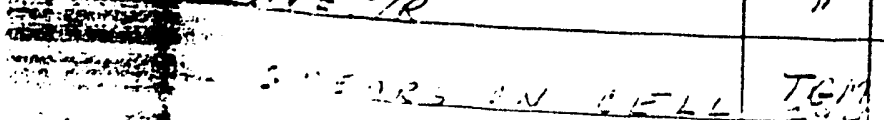

$=\ldots, 200,12$

1

\begin{tabular}{l|l}
$\prime \prime$ & \\
\hline
\end{tabular}

5000

Dist. $\pi / h$

DIST. ${ }_{A T}^{C / m}{ }^{\circ}$

(1)

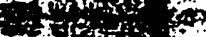

tonto

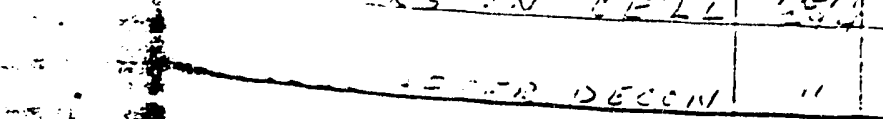

$+$

$+1$

.

160

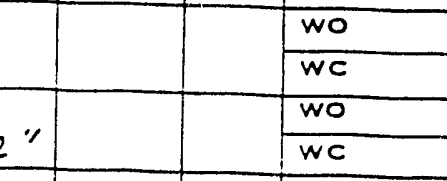

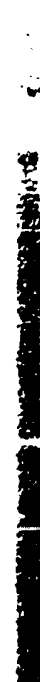




\section{RADIATION SURVEY}

\begin{tabular}{|c|c|c|c|c|c|}
\hline $\begin{array}{c}\text { UILOING NO. } \\
527\end{array}$ & $\begin{array}{l}\text { ROOMNO. } \\
\text { CAN YON }\end{array}$ & $\begin{array}{c}\text { S.W.P. NUMBER } \\
\text { s } 0 \mathrm{p}^{-}\end{array}$ & $7-22-63$ & $\begin{array}{l}\text { TIME OF SURVEY } \\
0930\end{array}$ & $\begin{array}{l}A M \\
P M\end{array}$ \\
\hline
\end{tabular}

MONITAR FUR BREWN INSTHLLING BARREL SN GATTLING

ALSA SURVEY TRUIK USED FOR HAVLIMGLATEING GUNLASK

T: DURIHL GRCUND ANDBACK

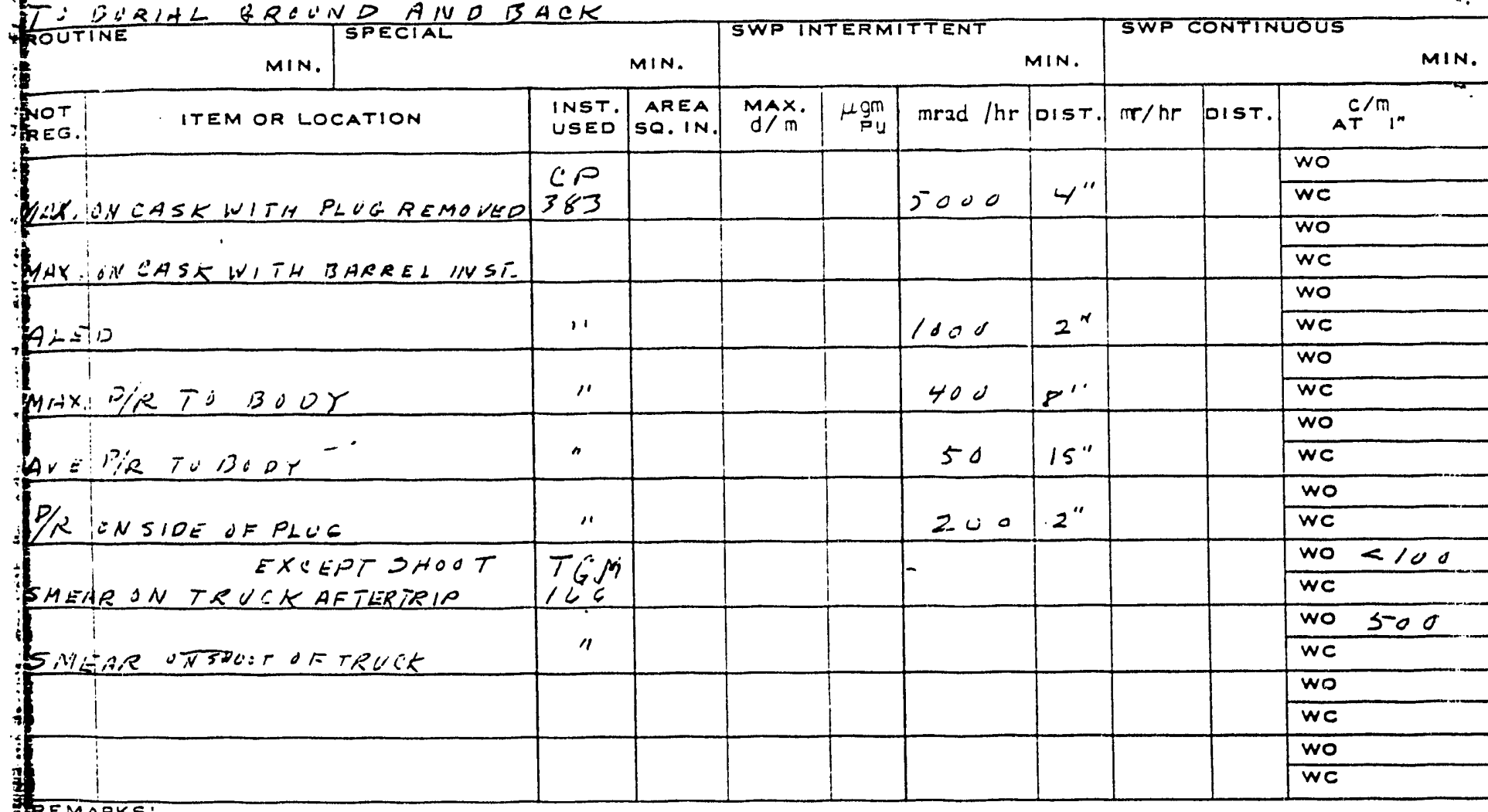

REMARKS:

TRULK SHOOT WHSCOVERED WITH RADIATLON SICNANU SEALE WITH NIASKLNË TAPE.

MAXIMUM RADIATION MEASUREMENT OBTAINED: 
i thith

WHC-MR-0416

UNCLASSIFIED SURVEY NO.

RADIATION SURVEY

06831

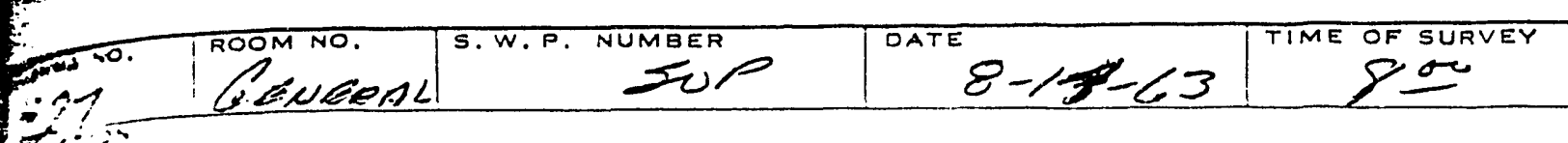

AM

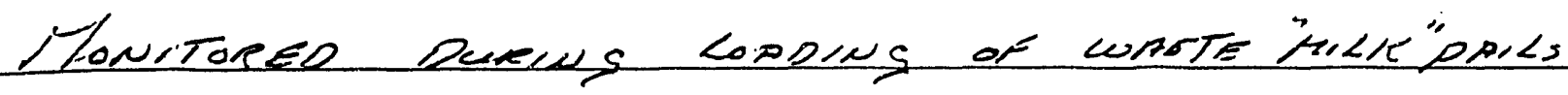
into cask's for Transele to Bureint Gardews,

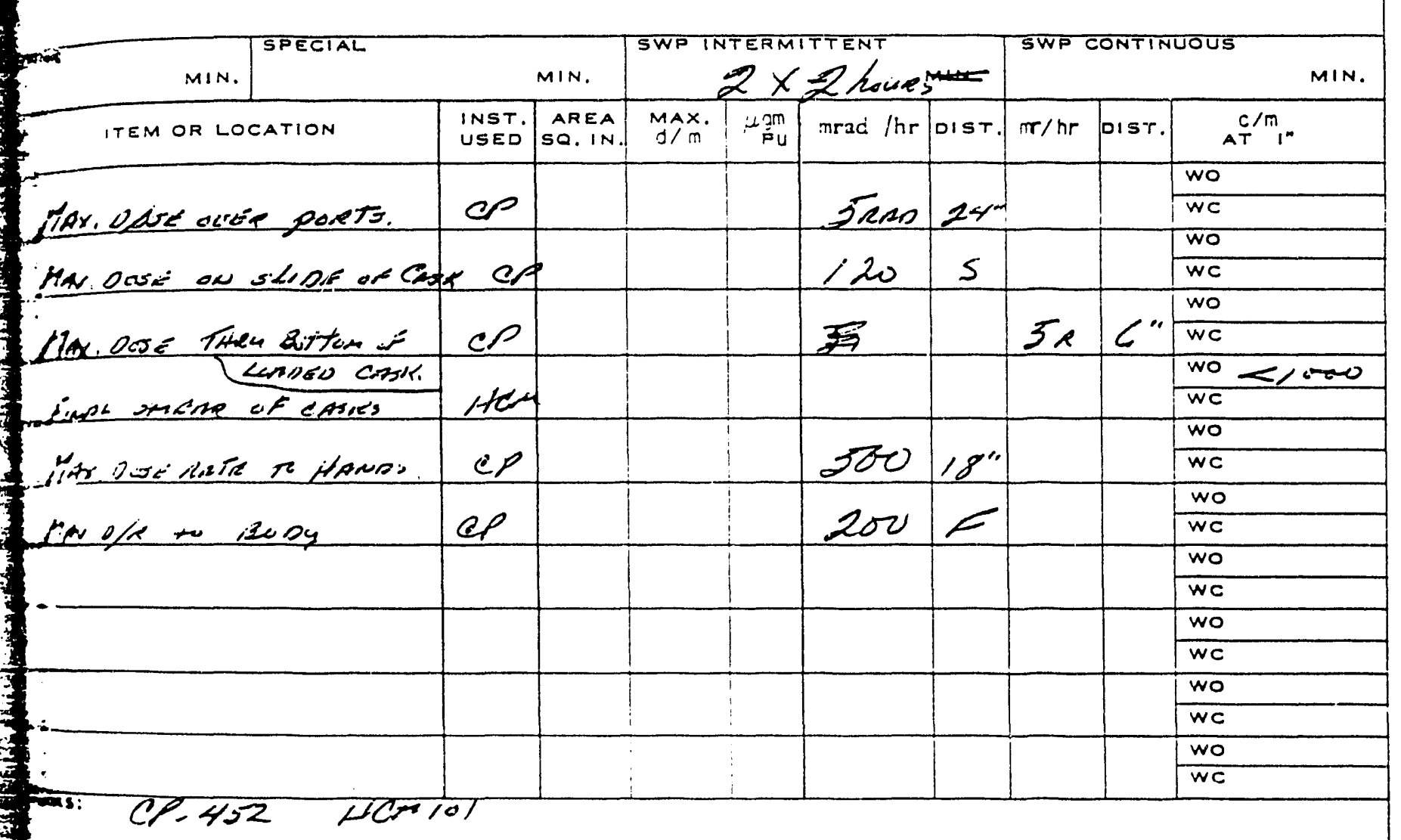

No. of pais: Eean cest:

W"

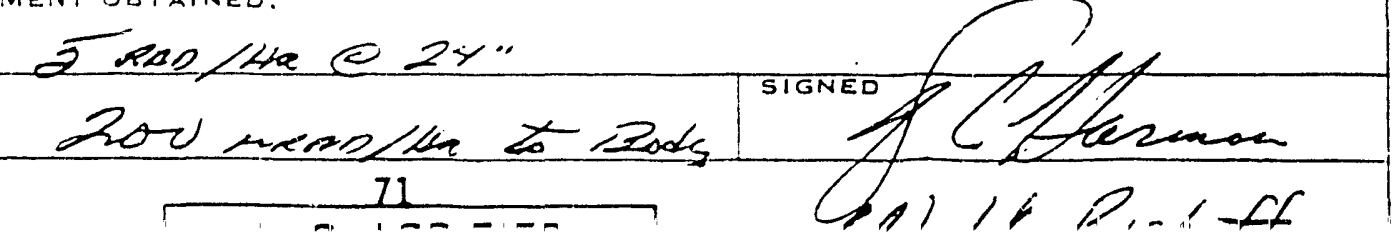




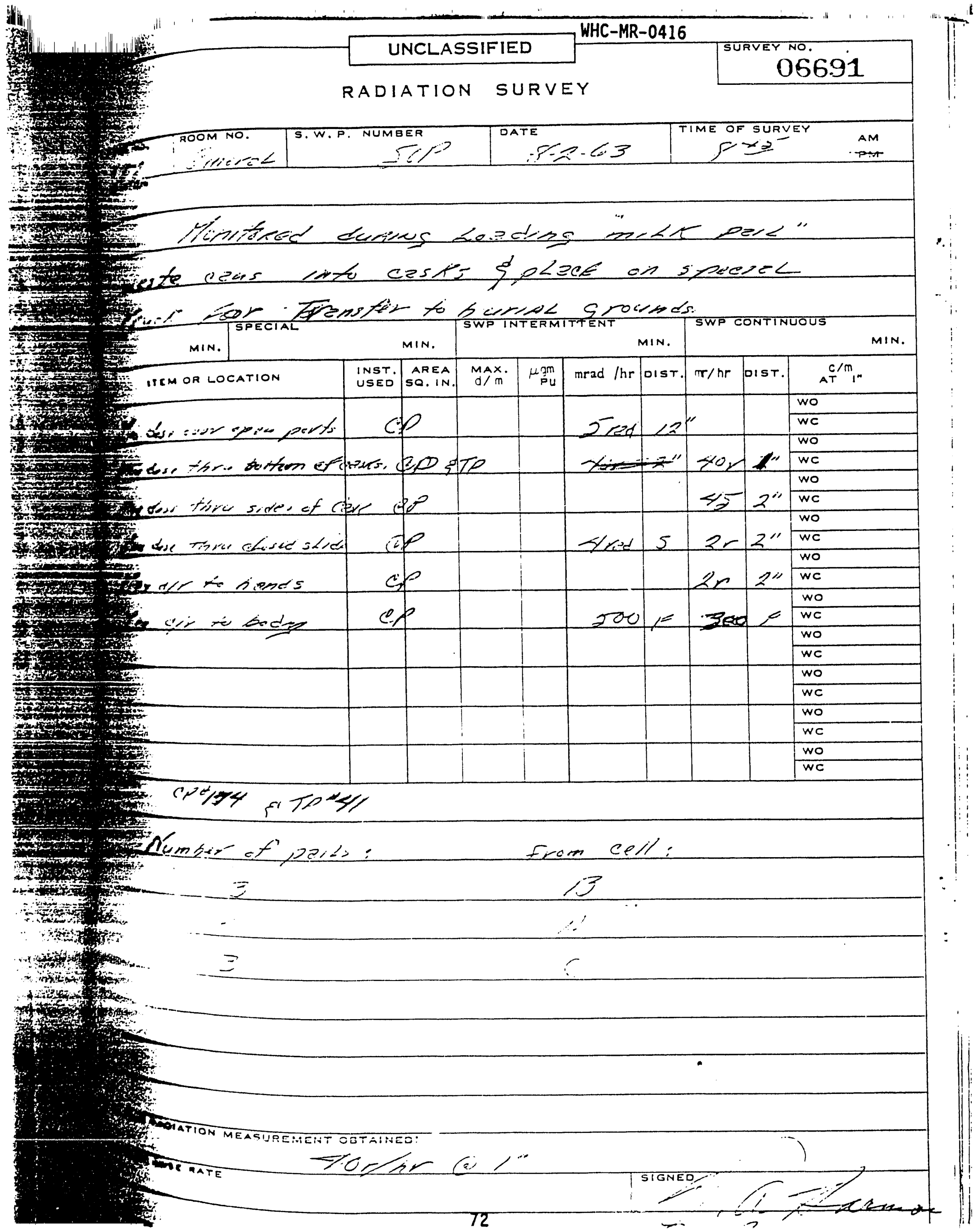




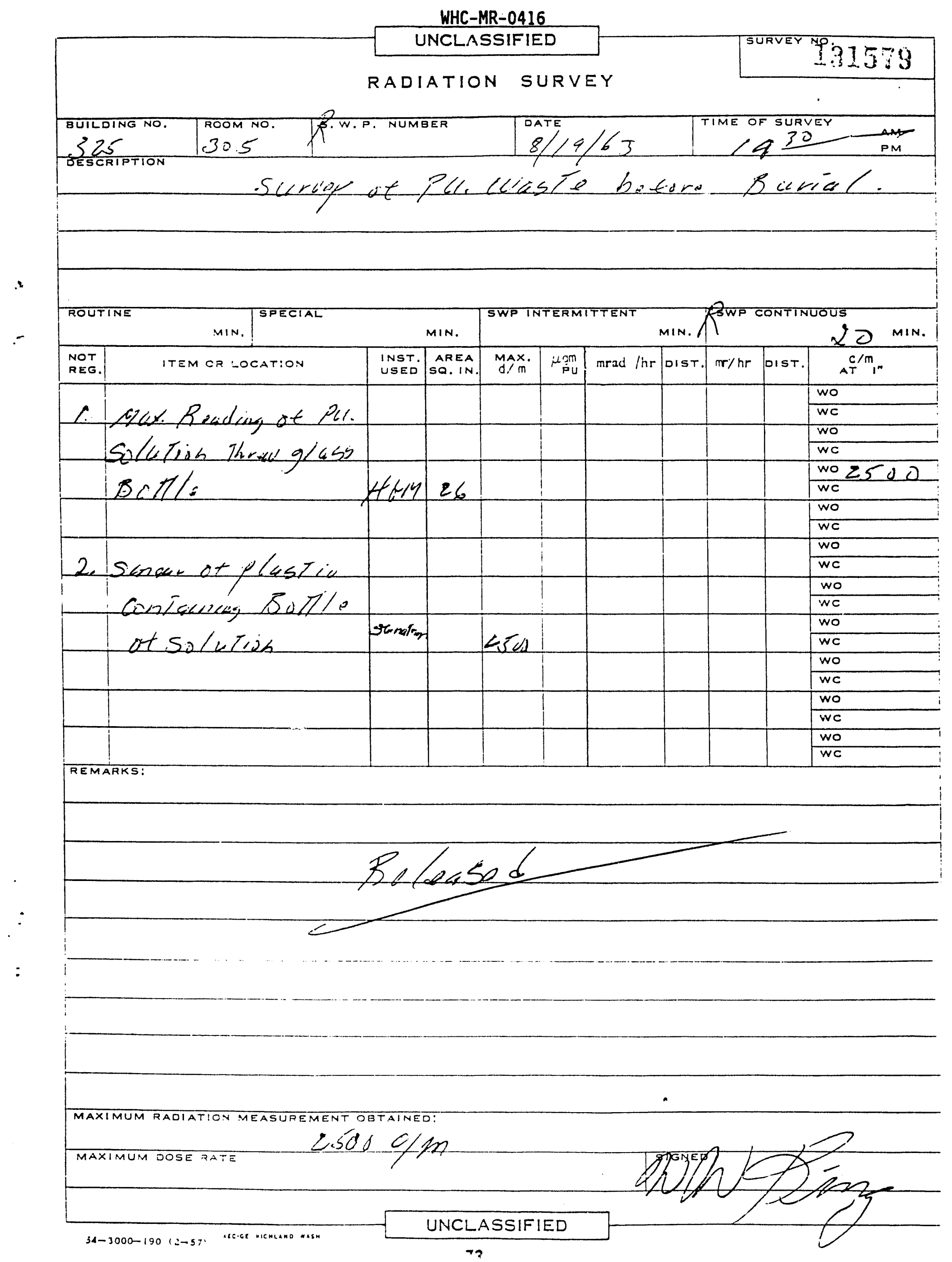




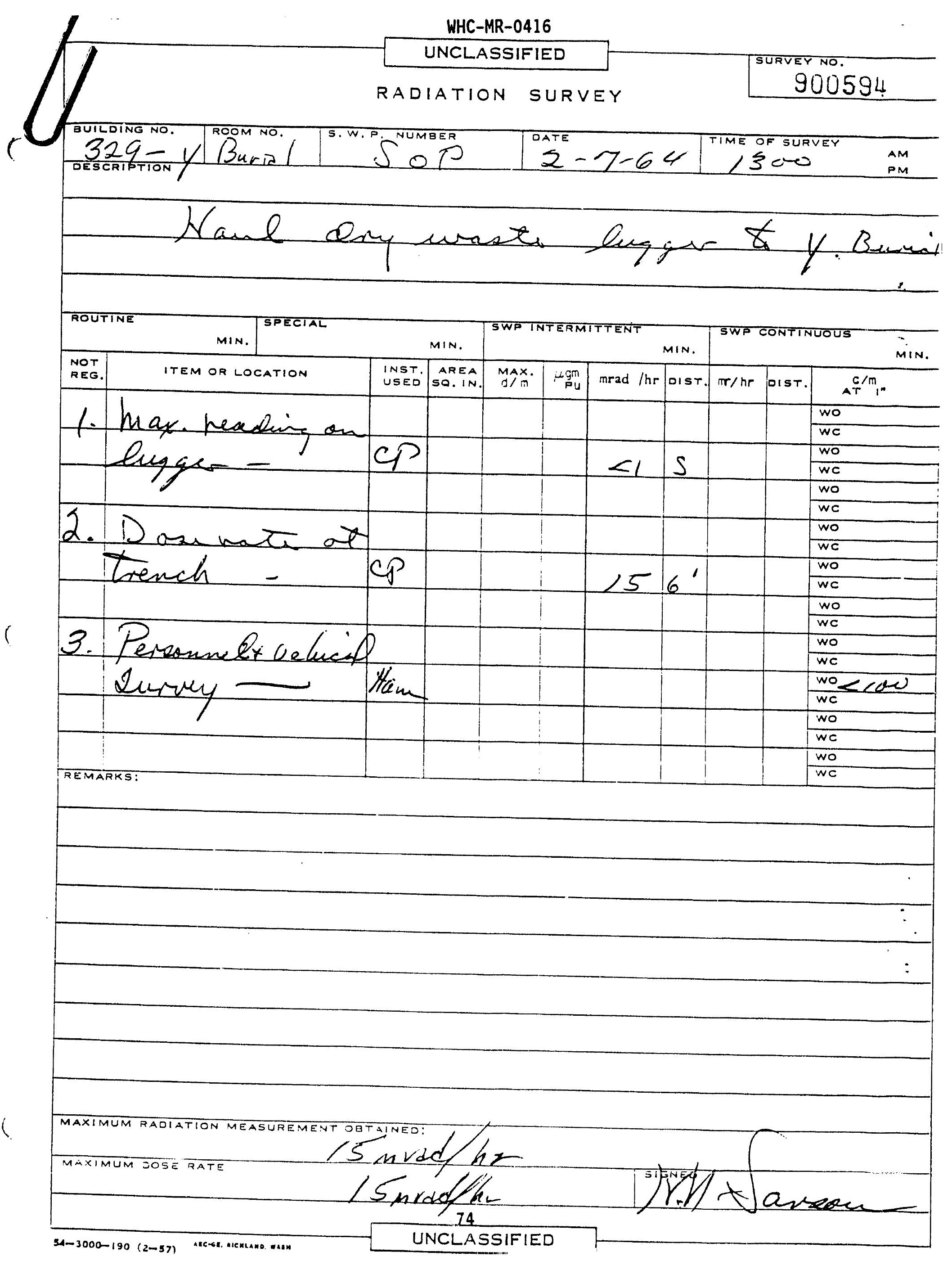


WHC-MR-0416

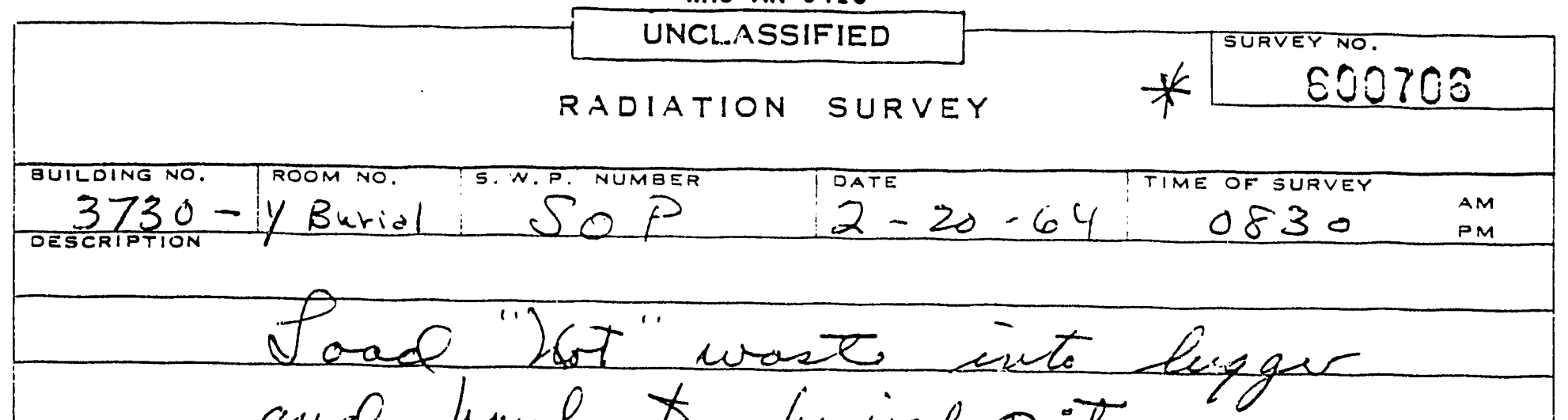
and haul to furial pit.

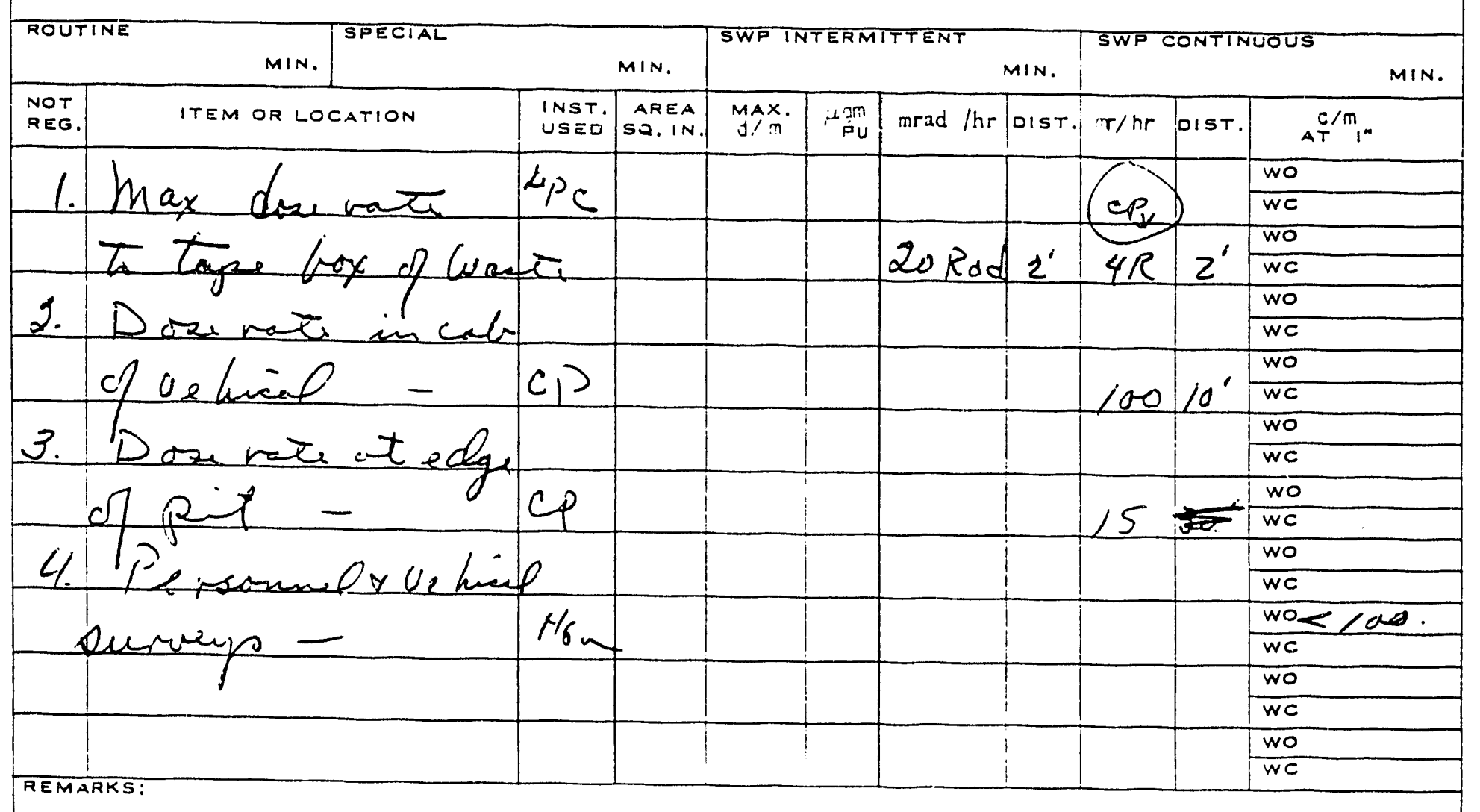
Pescomel concenud inforned of all
dose rates.

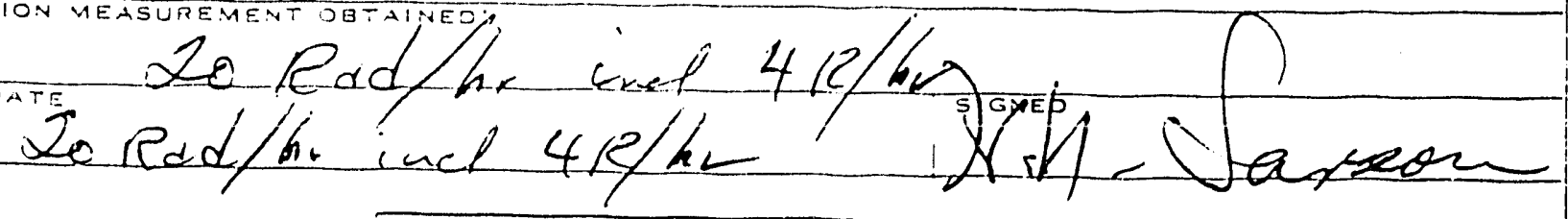

UNCL.ASSIFIED 


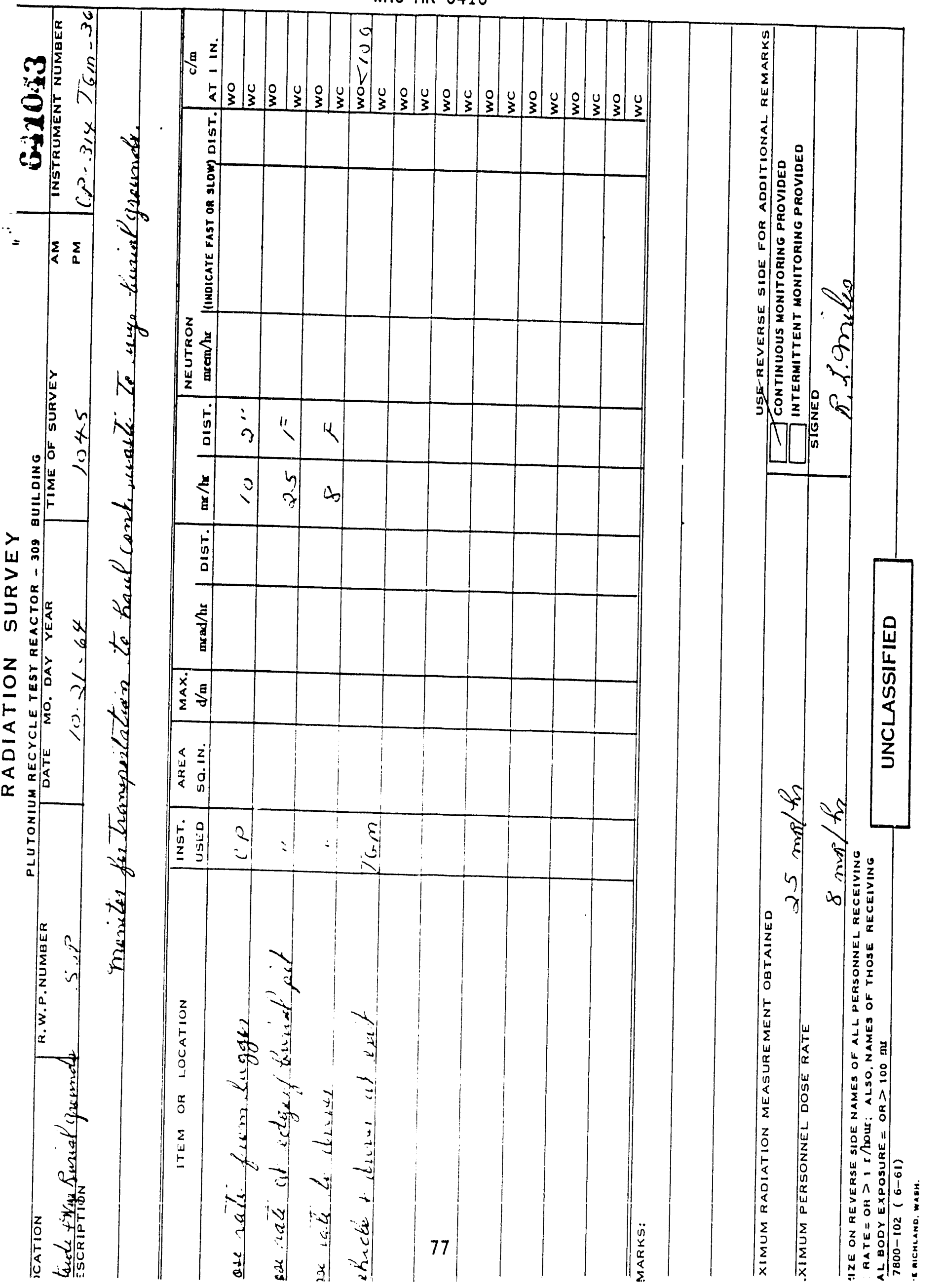




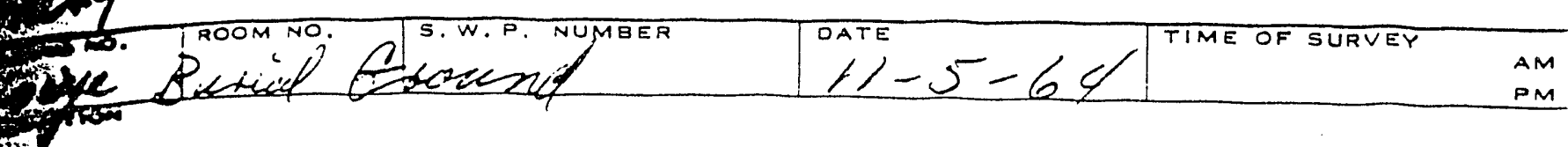

Monitix Dumping of 327 mill Pail Mear $325-A$ waste in 300 Wye Rumat Gtaried

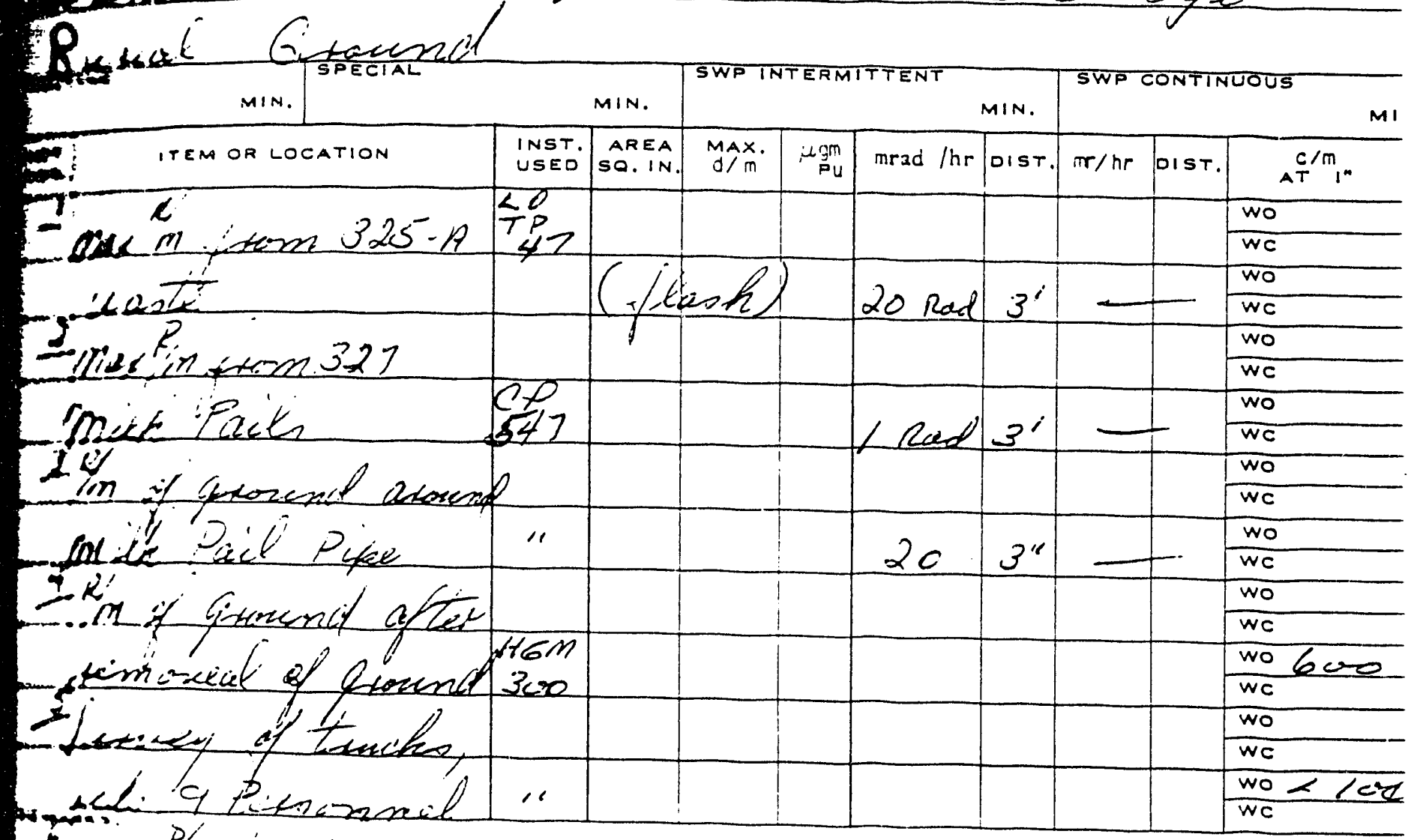

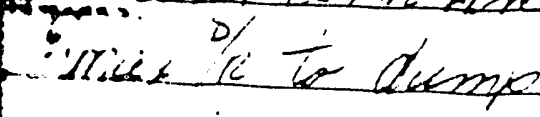

idite diemp

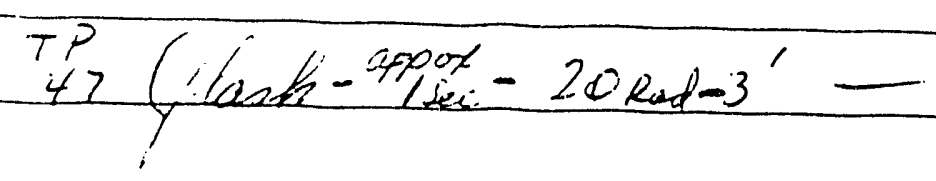

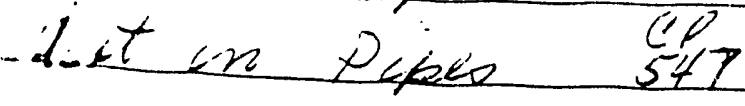

$2004^{\prime}-$

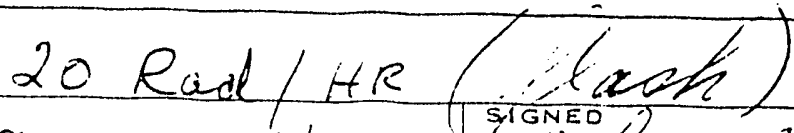
2 Lo Mudf HR IS Shathe UNCLASSIFIED

79 


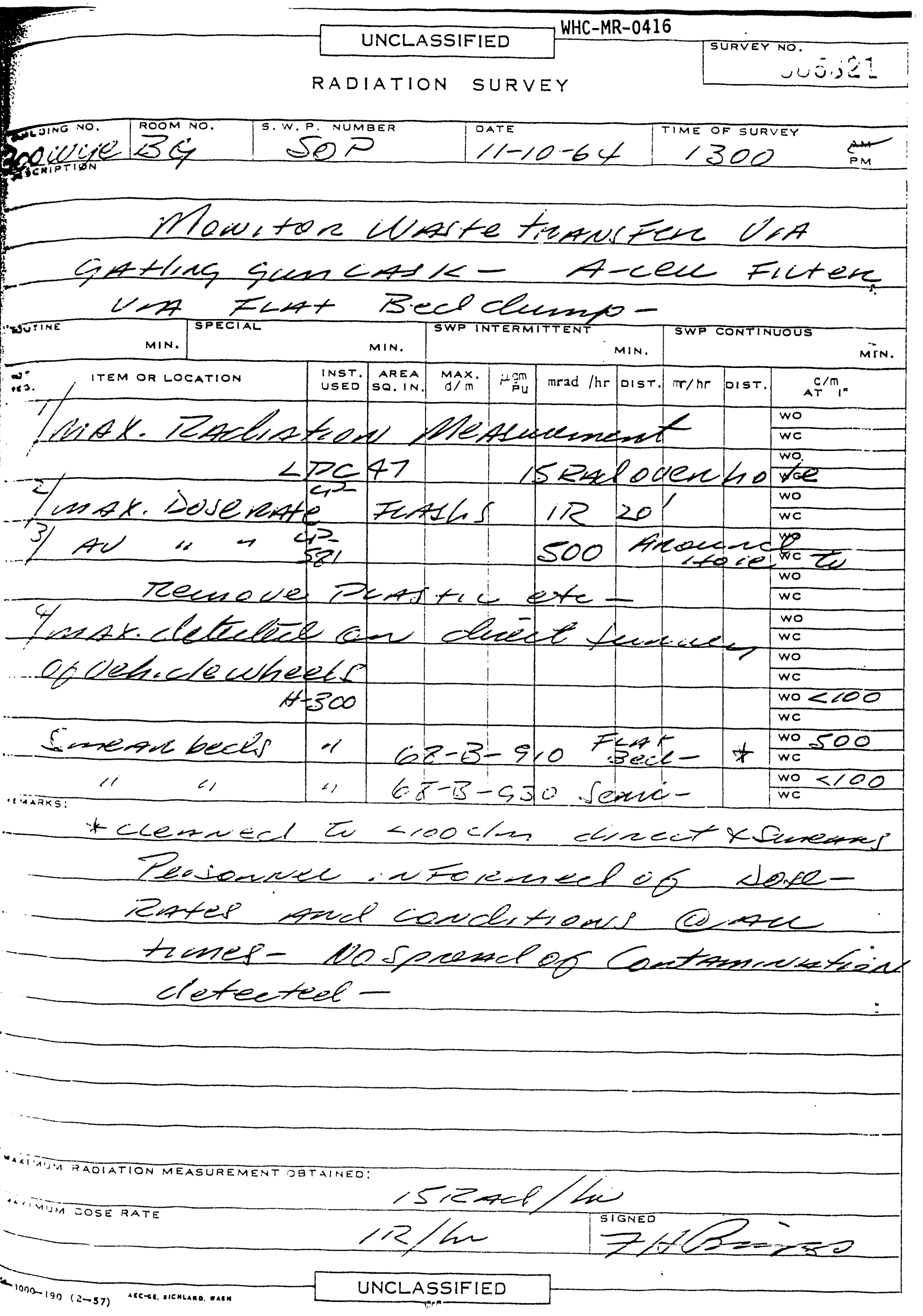




\begin{tabular}{l} 
WHC-MR-0416 \\
UNCLASSIFIED \\
\hline RADIATION SURVEY \\
\hline
\end{tabular}


筫

WHC-MR-0416

UNCLASSIFIED

TSURVEY NO.

RADIATION SURVEY

$6 ? 55 \% 5$

6

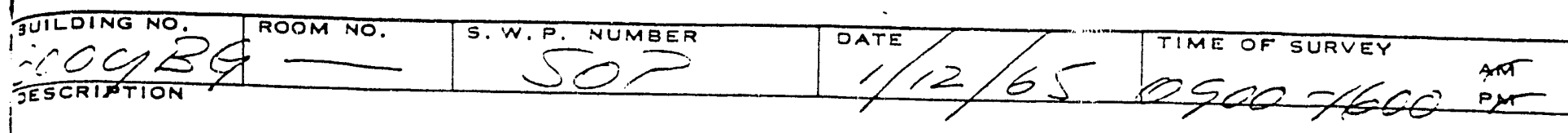

Plowitor wiste tuansfer Frem

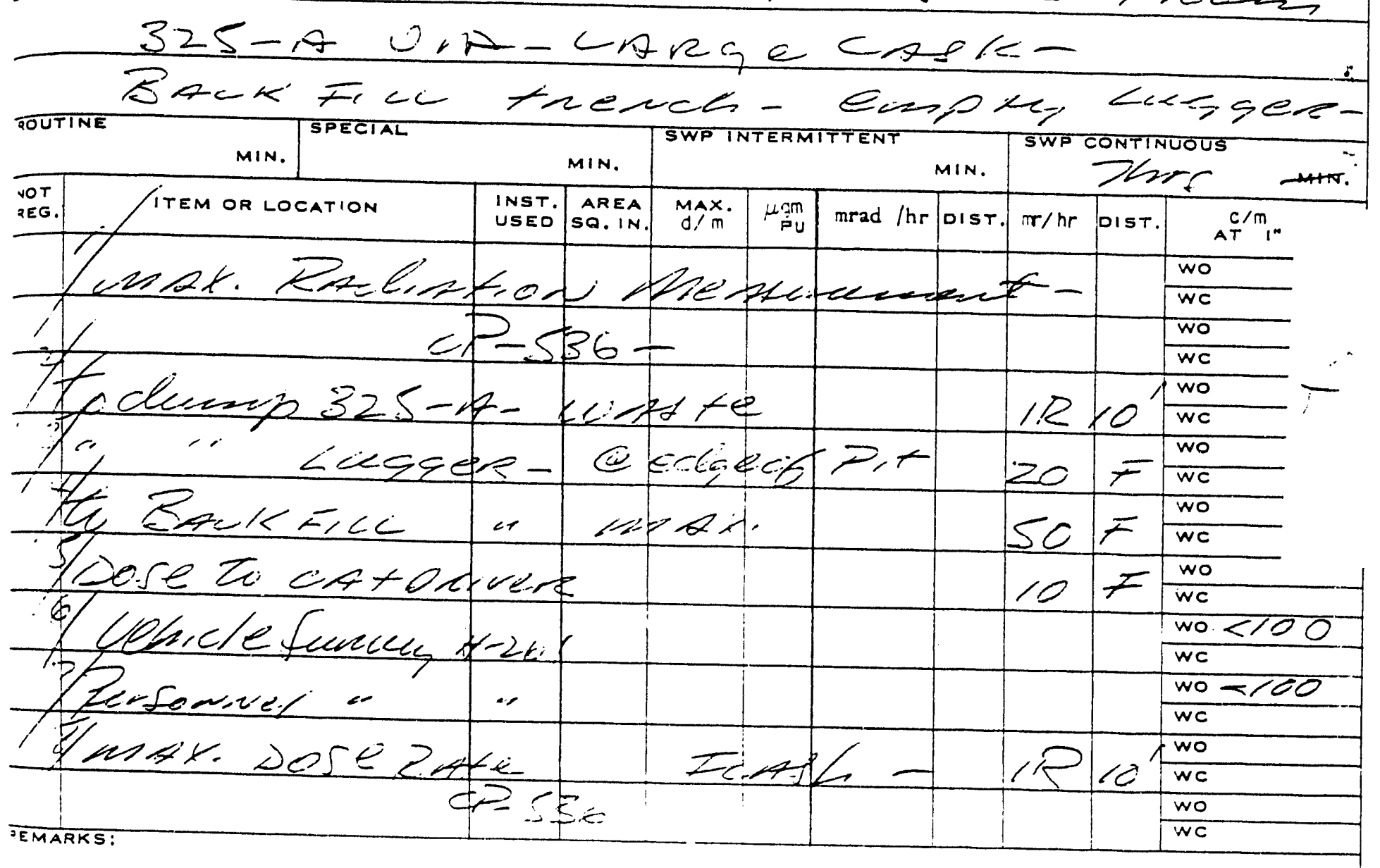

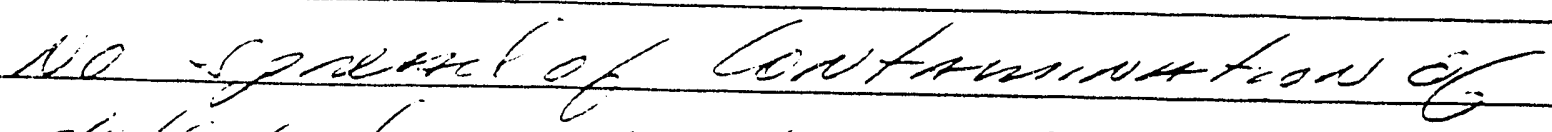
dettertel- lewt eivide trinch

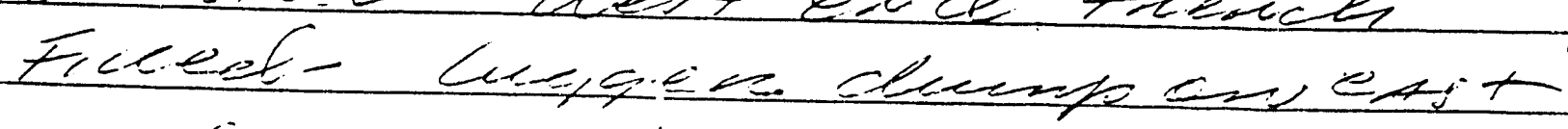

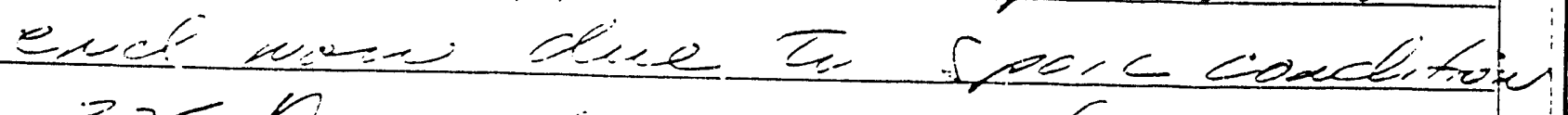

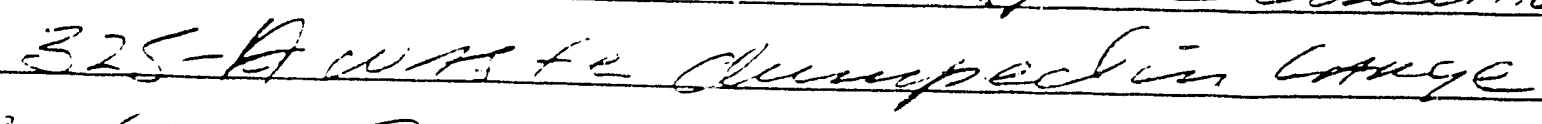
center pipe-

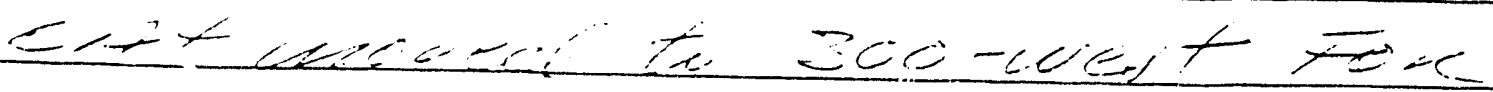
$-\frac{1}{2}=0$.

MAXIMUM RADIATION MEASUREMENT DGTAINED

AMXIMUM DOSE RATE

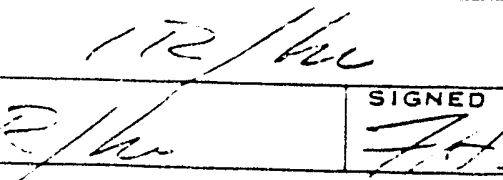

UNCLASSIFIED 


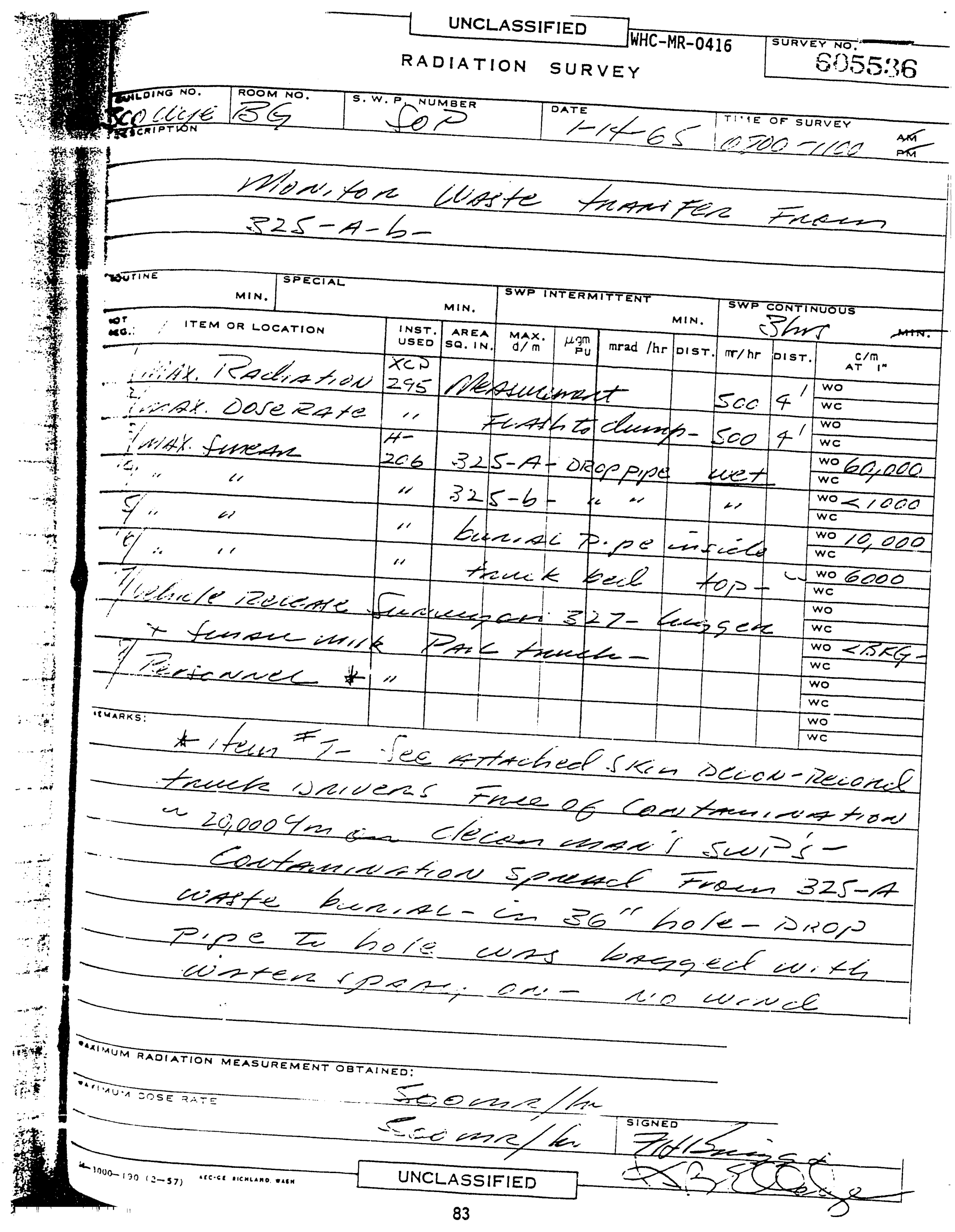




\begin{tabular}{l|l}
$\begin{array}{l}\text { Alomics Iniernational Division } \\
\text { Rochell Hanlord Opeiations }\end{array}$ \\
\hline
\end{tabular}

Commitment Made

Purpose of Telecon

To obtain information concerning plutoni 318-11 or "Y" burial ground) waste site.
iextof relecon
ir Hall stated that there were trace amounts of plutonium in the $618-11$ burial trenches

(for example from buried HEPA filters). However, the 618-11 caisons received solid waste Time
10:50 AM April 30, 1980

$\square$ incoming

R. B. Hall 942-3907

Fepresenting

HEDL

H. G. Jasen

Rockesenting Ranford Operations

from the destructive rietallurgical testing of reactor fuels. Mr. Hall remembers adding for this site that tutaled $4-5$ inventories on record sheets (waste management work sheets) for this site that totaled $10 \mathrm{kgs}$. of Pu, is a reasonab?e kilograms of plutonium. He feels that twice this quantity, quantity to assume for the 618-11 site inventory. Siowever, he notedric to Battelle areavalable to verify the $10 \mathrm{kgs}$. of $\mathrm{Pu}$ transfer.

number.

:

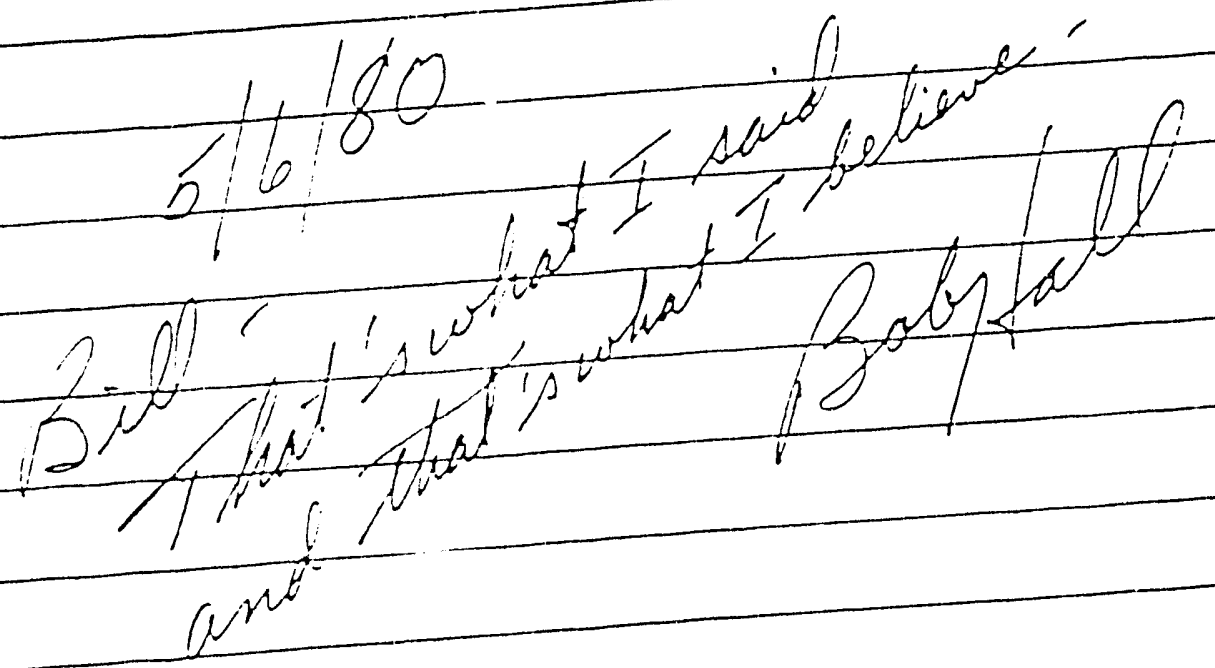


July 1, 1956

R. B. Hall.

RJ Sloat

SJ Beard o

GE Backman

O. M. Oatby.

(.......

$\cdots$

... Waste DLoposal and Decontamination Monthly

$\because \ldots$. B . Report, June 1966

$\therefore+\therefore:$

Weste Dlsposal Operation

The following sumarizes the Waste Dlsposal Operation:

\section{Item}

Apr 11

May

Concrete Waste Barrels disposed to $200-\mathrm{W}$

Burlal Ground

0

9

Cublc feet of dry waste disposed to the

$\rightarrow 300$-Wye open trench from 300 area sites other than the 325 bullding.

$\therefore-$

:- :

Cubic feet of dry waste disposed to the

$\rightarrow$ 300-Wye open trench from 325 building.

Cuble feet of dry waste disposed to tho

200-W Burlal Ground by BNW.

$$
\begin{aligned}
& 308 \text { Bullding } \\
& \because 325 \text { Build1ng } \\
& \therefore \text { 231-z Bullding } \\
& \text { 108-F Bu11d108 } \\
& \text { 222-U Bullding } \\
& \text { 292-T Bu1lding } \\
& \text { 221-T Bullding }
\end{aligned}
$$

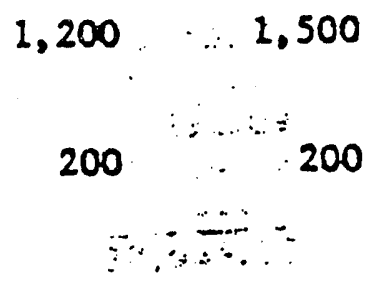

$\begin{array}{cc}402.5 & .57 .5 \\ -.- & -. \\ 689.5 & 221.5 \\ 466.25 & 341.25 \\ 49.5 & 66.0 \\ 9.0 & 9.0 \\ \ldots- & 67.5\end{array}$

Containers of high level dry waste disposed $\rightarrow$ to 300-Wye waste tanks and tubes.

\section{$340 \mathrm{CrLb}$ Wasce}

Crib Waste Volume, Gals

Total Beta Concentration uc/gal.

Total Beta Curfes

Total Alpha Concentration uc/gal.

Total Alpha, MC

Pu Concentration, ug/gal.

smount $\mathrm{Pu}, \mathrm{g}$.

U. Concentration $\mathrm{mg} / \mathrm{gal}$.

Amount $U, \mathrm{Rg}$.

$\begin{array}{cc}45 & 71 \\ * & *(216-z-7) \\ 220,000 & 175,000 \\ 887 & 450 \\ 195 & 78 \\ .3 & .62 \\ 66 & 108 \\ 2.5 & \text { NA } \\ .55 & \text { MA } \\ \text { NA } & \text { NA } \\ \text { NA } & \text { NA }\end{array}$


DAte August 2, 1966

To' R. B. HaII

FROM L. Y. Ostby

SUEJECT WASTE DISPOSAL MONTHLT REPORT
B. I. McMurray

R. J. Sloat

S. J. Beard

تaste Disposal Operation

The following sumarizes the Waste Disposal Operation:

Ilem May June

Concrete waste barrels disposed to $200-W$

Burial Ground

Clioic feez of dry waste disposed to the

(6/8-11) 300-Wye open trench from 300 Area sites

ocher than the 325 Building

1500

1600

Cubic feet of dry waste disposed to the

300 -Wye open trench irom the 325 Building

200

300

Cubic feet of dry waste disposed to the

200-W Burial Ground by BiwW

$$
308 \text { Building }
$$

325 Builuing

547.5

231-z Building

$108-F$ Building

222-U Building

292-T Building

221-T Building

-.

221.5

314.25

66.0

9.0

67.5

526.5

65.25

355.25

387

72

45

40.5

Concaintes of high level dry waste disposed

to 300 -Wye waste tanks and tubes

71

68

\section{Crib Waste}

Crio Waste Volume, Gals.

Total Beta Concentration uc/gal.

Toral Beta Curies

Total Alpha Concentration uc/gal.

Total Aipha, MC

: Pu Concentration, ug/gal.

Amount Pu, g.

$U$ Concentration mg/gal.

Amount U, $\mathrm{Kg}$.

* Split to Cribs $216-z-7$ and $216-T-34$ as reported in June.

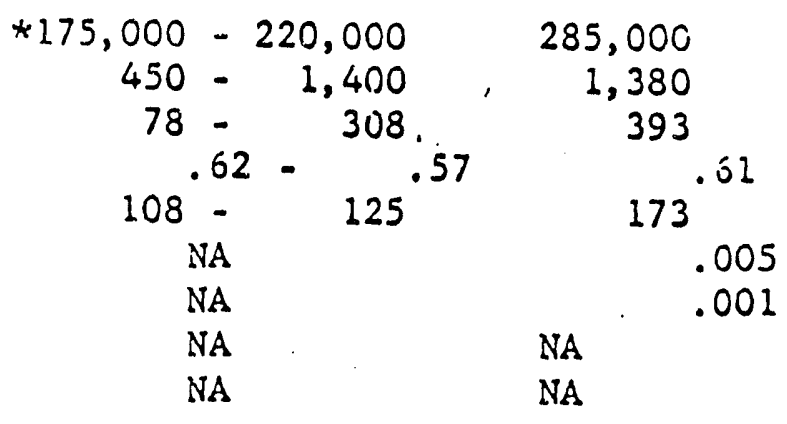

84- 1000-002 (10-04)

secten nicwente. wan. 


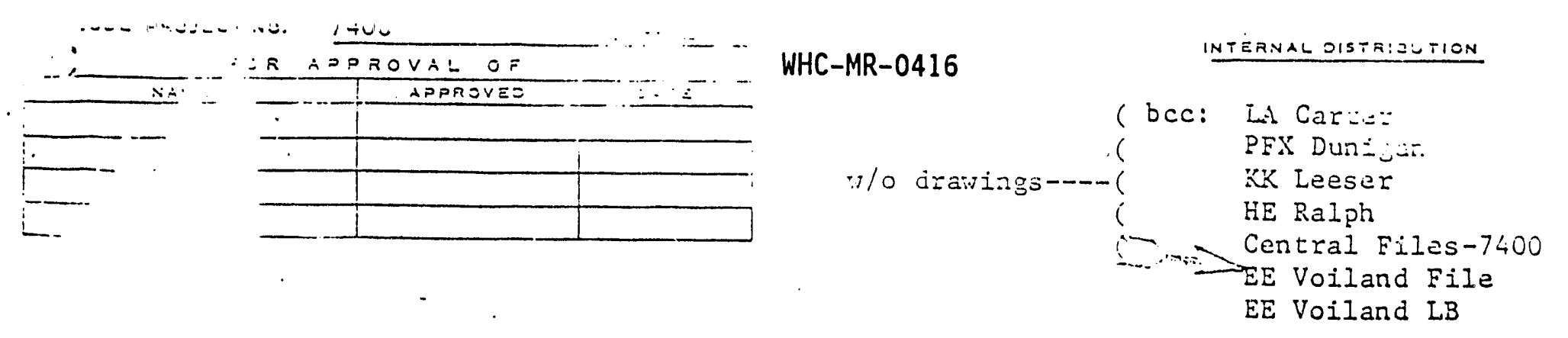

Feliruary 2, 1970

Mi. Erank S. Zvoaar

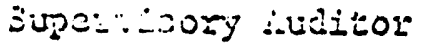

- S. AzLidi Accounting ofeica

3de:- -

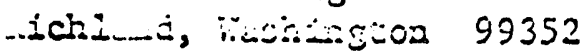

Daar ’: Zvorar:

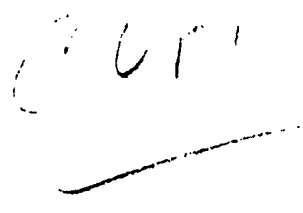

Waste Burial Ground Diear Pacific horthiost Laboratory Sires

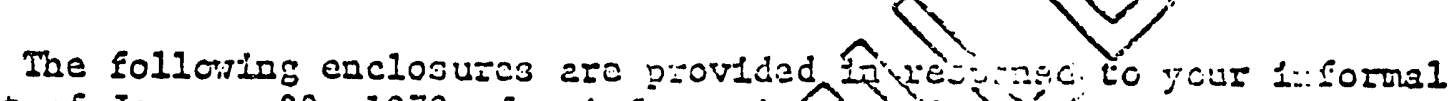

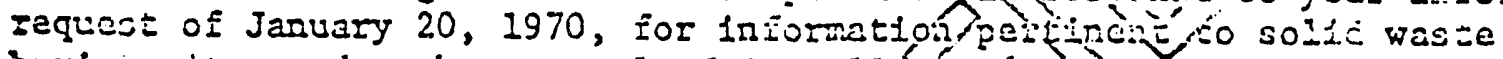
burfic jites under the control of Battelle florthost. If furcuar taforma-

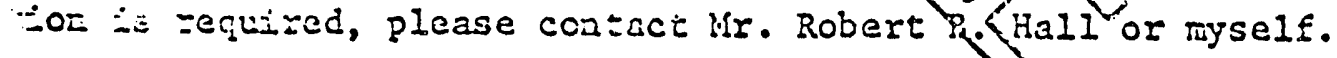

(i) Table - Waste Iurial Ground Data, Pac1fle Northwest Laboratory S1tes
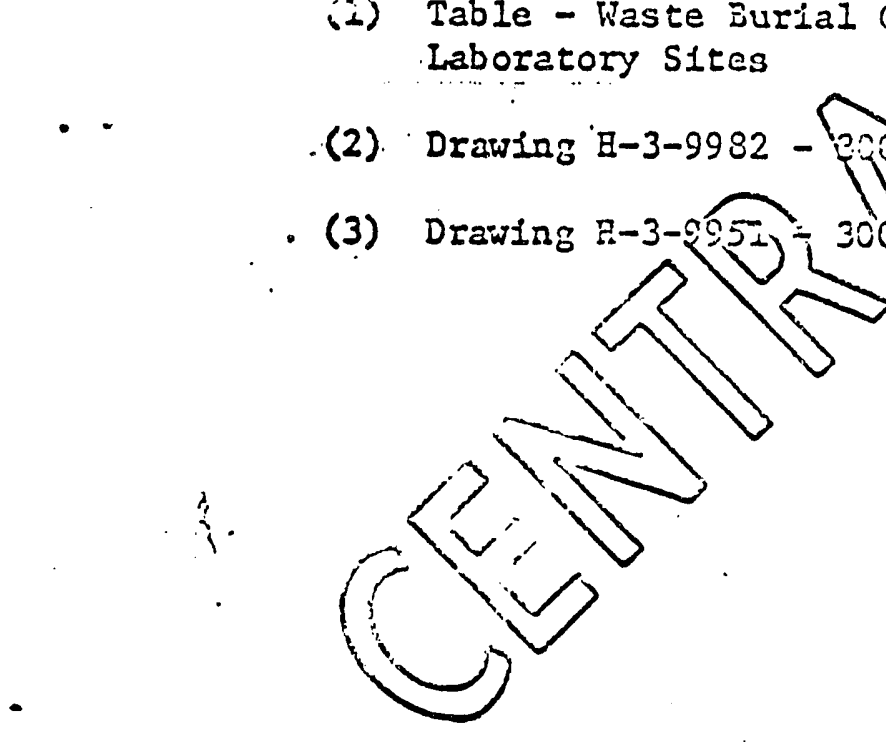

Sincerely gours,

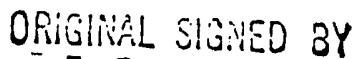

E. 是 !UILAND

Z. 3. Volland

BiN Repzesentat1ve

WASTE MANAGEMENT ADVISORT BOAND . $=C-R I$

$$
\begin{aligned}
& \text {. } \nabla: . ـ \\
& \text { Eil juras }
\end{aligned}
$$

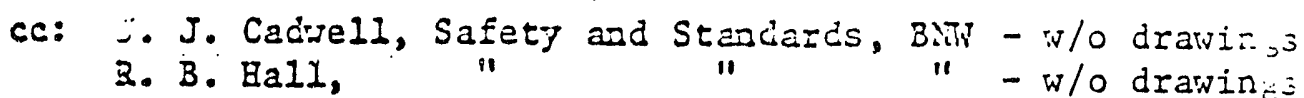




$$
\text { . } \quad 1-30-70
$$

Waste Burfal Ground Data

Paclfic Northwest Laboratory Sites

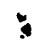

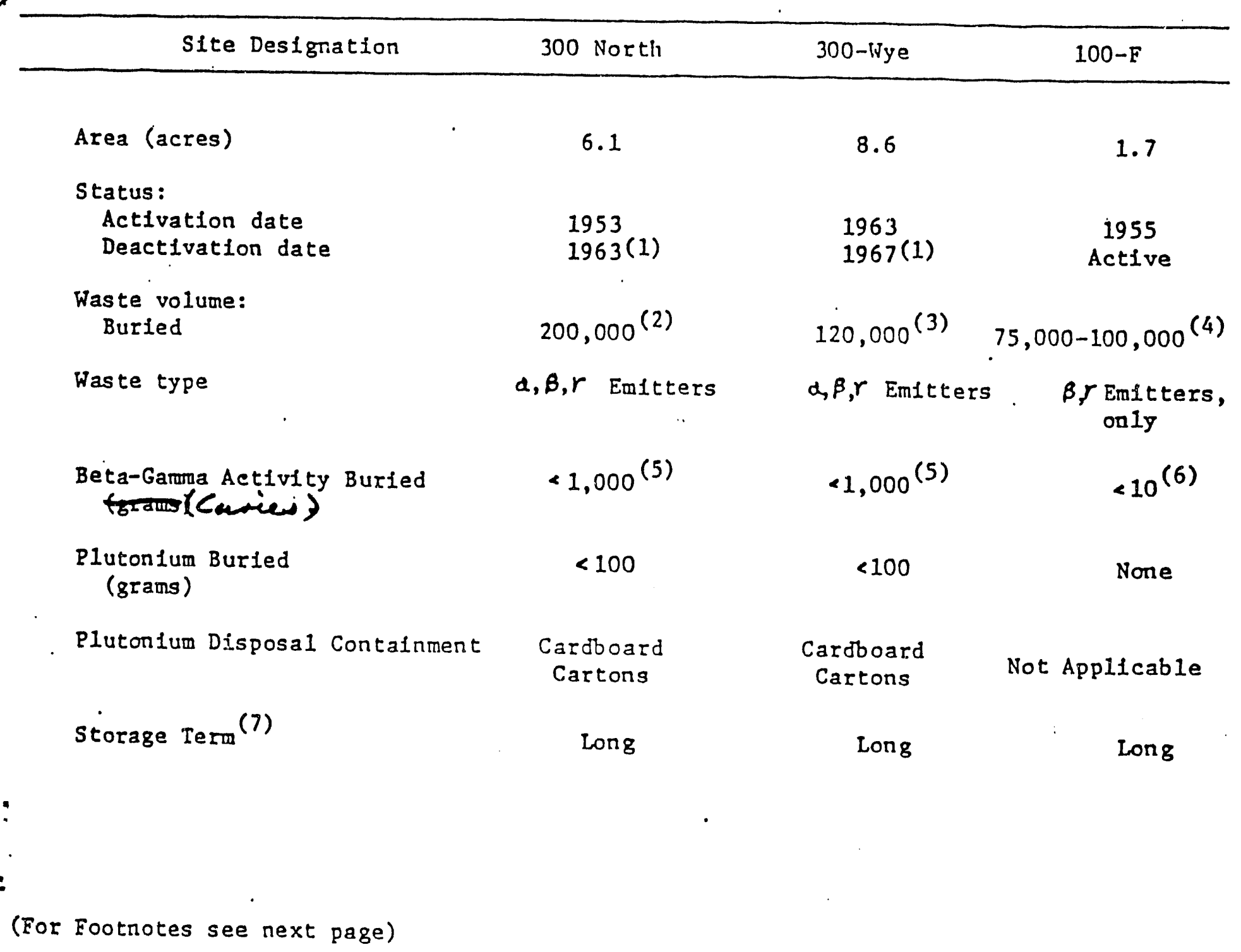


PNL Waste Burial Ground Data

\section{Footnotes:}

(1) Deactivation according to Hanford Standards.

(2) Data on the quantity of waste buried were not available from records readily available since the burial site was operated when General Electric Company was prime contractor. A knowledge of laboratory programs and

- burlal site utilization suggests that 200,000 cubic feet is a reasonable estimate.

(3) Based on "load-Iugger" count.

(4) Estimated on a basis of 5,000 to 6,000 cubic feet per year.

(5) In volume, the largest part of the buried wastes consists of slightly contaminated (or possibly contaminated) rubber gloves, wipes, apparatus, etc., from bench scale experimentation with uranium or tracer level radionuclides. The bulk of the buried radioactivity, however, is concentrated in a relatively small volume. It arises from process demonstrations with extensive quantities of radionuclides and is buried in "caissons" located in specific areas of the burial sites. Very little -If any -- plutonium was buried in cartons in the trenches. Recognized plutonium wastes were either contained in concrete, confined to the "caissons", or shipped to 200-West burial sites. It should be noted that these burlal grounds have also been used for disposal of beryllium.

(6) Primarily tracer level radionuclides from blological research.

(7) These sites are intended for indefinite long-term storage (under periodic surveillance) until such time as a procedure for ultimate disposal has been established. Such long-term planning is currently being undertaken for Hanford wastes by the Waste Management Advisory Board, AEC-RL. 
300-WYE Burial Ground

Status: Inactive; operations terminated December 1967.

Reference Drawing: H-3-g95I

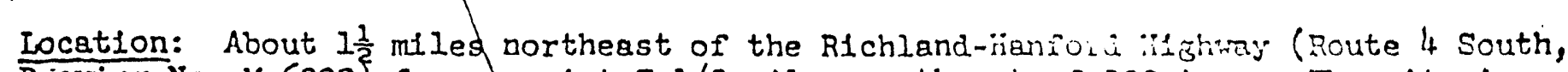
Drawing No. M-6000) from a point $7-1 / 3$ miles northwest of 300 Area. The site 18 In Sec. 5, TllN, R28E Willamette Merldian.

Descriotion: The site conshsts of a $375^{\prime} \times 1000^{\prime}$ rectangle orlented east-west. Total area is 8.6 acres.

$\because$

Burlal faclilties include three backfilled trenches $900^{\prime} \times 50^{\prime}$ occupylng all of the site except a $100^{\prime} \times 1000^{\prime}$ strip on the north side. In the eastern half af this northerm portion are located 50 vertical plpe storage units made by welding five 55-gallon'drum sections together. Just west of the pipe installations are four calsson storage faclifties consisting of $8^{\prime}$ diareter $x$ 10' high 8-gauge corrugated metal pipe, burled $15^{\prime}$ below grade and connected to the surface by offset 36" pipe. All pipe and caisson aisposal facilities have been backfilled, capped off with concrete and covered with dirt.

The burial ground perimeter is marked with Identification Markers 2-68-1 through 2-68-28.

Burial Site Contenta; The ste 18 a repository for a broal spectrum of low-to. high-level dry radioactive wastes, primarliy fission products and plutonium. Cartoned low level wastes were burled in the trenches and medium-to-hlgh-level beta-ganms wastes in the pipe faclilties and calssons.

Quantities probably amount to thousands of curles of beta-gama wastes and $10^{\prime} 8$ to $100^{\prime} s$ of grams of plutonlum.

Remarks: Th1s s1te was ret1red in December 1967 in favor of burylng all wastes in the 200 Ares burial grounds. At closure of the burlal ground, one trench bad not been completely used. 
WHC-MR-0416

\section{DISTRIBUTION}

Number of Copies

Onsite

1

U.S. Department of Energy, Richland Field Office

Public Reading Room

A1-65

9

Westinghouse Hanford Company

C. R. Webb (5)

H6-04

Document Processing \&

Distribution (2)

L8-15

IRA

H4-17

Central Files

L8-04

Distr-1 

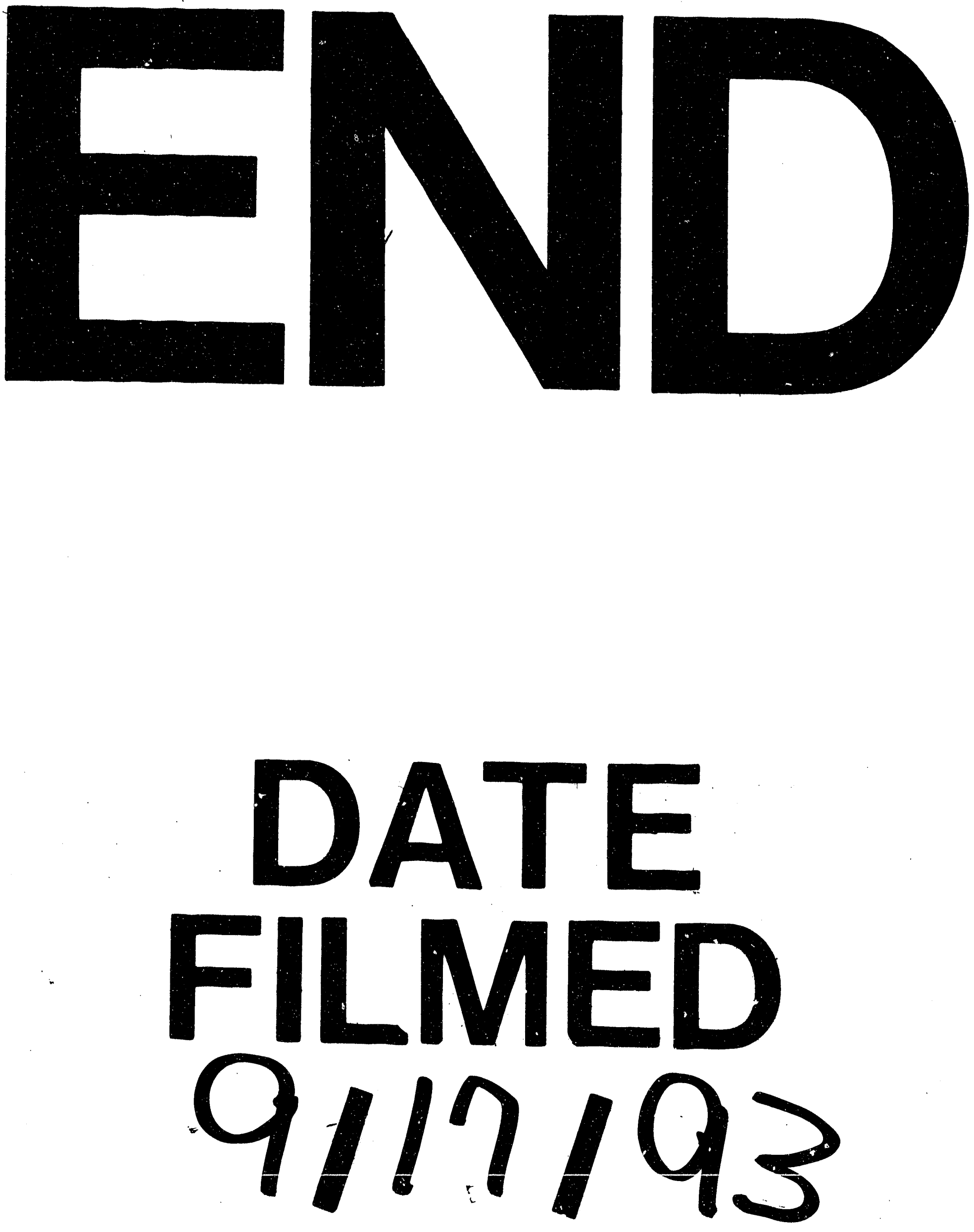
ב 